UNIVERSIDADE DE SÃO PAULO

FACULDADE DE MEDICINA DE RIBEIRÃO PRETO

PROGRAMA DE PÓS-GRADUAÇÃO EM IMUNOLOGIA BÁSICA E APLICADA

Josiane Aparecida de Carvalho

Lipocalina bovina e o seu papel na resistência ao carrapato: quantificação em líquidos corporais de raças bovinas com fenótipos contrastantes de infestações com o carrapato Rhipicephalus microplus

Ribeirão Preto - SP

2016 


\section{JOSIANE APARECIDA DE CARVALHO}

\section{Lipocalina bovina e o seu papel na resistência ao carrapato: quantificação em líquidos corporais de raças bovinas com fenótipos contrastantes de infestações com o carrapato Rhipicephalus microplus.}

Dissertação apresentada a Faculdade de Medicina de Ribeirão Preto - USP para obtenção do título de mestre em Imunologia. Área de concentração: Imunologia Básica e Aplicada.

Orientadora: $\operatorname{Prof}^{\mathrm{a}} \operatorname{Dr}^{\mathrm{a}}$ Isabel Kinney Ferreira de Miranda Santos

Ribeirão Preto - SP 
Autorizo a reprodução e divulgação total ou parcial deste trabalho, por qualquer meio convencional ou eletrônico, para fins de estudo e pesquisa, desde que citada à fonte.

Ficha Catalográfica

Carvalho, A. Josiane

Lipocalina bovina e o seu papel na resistência ao carrapato: quantificação em líquidos corporais de raças bovinas com fenótipos contrastantes de infestações com o carrapato Rhipicephalues microplus Orientadora: $\operatorname{Prof}^{a} \operatorname{Dr}^{a}$ Isabel Kinney Ferreira de Miranda Santos Ribeirão Preto, São Paulo, 2016.

$89 \mathrm{f}$.

Dissertação (Mestrado) - Universidade de São Paulo, 2016

1. Lipocalina bovina. 2. Odorant binding protein. 3. Resistência e suscetibilidade. 4. Rhipicephalus microplus. 
Nome: Josiane Aparecida de Carvalho

Título: Lipocalina bovina e o seu papel na resistência ao carrapato: quantificação em líquidos corporais de raças bovinas com fenótipos contrastantes de insfestações com o carrapato Rhipicephalus microplus

Dissertação apresentada à Faculdade de Medicina de Ribeirão Preto USP para obtenção do título de mestre em Imunologia.

Área de concentração: Imunologia Básica e Aplicada

Aprovado em:

Banca examinadora

Prof(a) Dr(a): Isabel Kinney Ferreira de Miranda Santos

Julgamento: Assinatura:

Prof Dr:

Julgamento: Assinatura:

Prof Dr:

Julgamento: Assinatura: 


\section{AGRADECIMENTOS}

Primeiramente aos meus pais, João e Lourdes, por me oferecerem um dos maiores e melhores bens - o estudo. Sempre acreditaram na minha capacidade, e me apoiaram em tudo. Obrigada pelo amor incondicional. Saiba que sem vocês seria impossível alcançar mais essa vitória.

À minha irmã, Juliana, meu irmão Gleison que mesmo distante sempre me impulsionaram em direção às vitórias de meus desafios, e ao meu querido e amado sobrinho Gustavo que faz os meus dias mais felizes.

À Prof ${ }^{a} \operatorname{Dr}^{\mathrm{a}}$ Isabel Kinney Ferreira de Miranda Santos, minha orientadora, por ter me mostrado o caminho da ciência.

Ao Dr. Kenji Fukuda, por ter cedido o anticorpo utilizado nos experimentos, e pela orientação e discussões sobre alguns resultados.

Ao pessoal do Instituto de Zootecnia - IZ de Nova Odessa e da Universidade do Estado de São Paulo- Campus Pirassununga, que me auxiliaram nas coletas.

Aos irmãos que Deus colocou em minha vida Karoline Biffi, Naira Anchieta, Davi Lagatta, Pedro Alexandre Sampaio, Amanda Goulart, Luna Lacerda, Ítala Silva, Rômulo Oliveira, Rafaela Felício, Leandro Ávila, Luiz Gustavo Nogueira, Bruna Bertol, Mouzarllem de Barros, Carolina Barroso e Mychelly Carlin sem vocês o caminho seria mais difícil.

A todos meus colegas do laboratório, em especial ao Thiago Malardo pelas várias discussões cientificas.

Aos meus amigos e confidentes Luana Augusta, Paula Borges, Andresa Graziela, Rafaela Esteves Guimarães, Maria Amélia, Ricardo Souza, Isadora Lima e todos que cresceram comigo, obrigada pelo apoio que mesmo longe estavam tão presentes.

Aos professores, funcionários e amigos, da pós-graduação e da Faculdade de Medicina principalmente a Dorlei que é uma segunda mãe para mim, ao Wander, a Mara, Wendy, Isa, Aninha, Ana Flavia, os quais foram meu apoio profissional e emocional, que foram essenciais para o andamento do trabalho.

A dona Cida e o senhor Ênio responsáveis pelo local onde morei nesse período, que me ajudaram muito.

À secretária da Pós-graduação em Imunologia Básica e Aplicada, Ana Cristina, por todo o carinho e ajuda durante este período no programa. 
À banca avaliadora pela participação e pela disponibilidade.

E a todos aqueles que de alguma forma contribuíram para a realização deste sonho, meus sinceros agradecimentos. 
"Pensamos demasiadamente e sentimos muito pouco.

Necessitamos mais de humildade que de máquinas.

Mais de bondade e ternura que de inteligência.

Sem isso, a vida se tornará violenta e tudo se perderá"

Charles Chaplin 
CARVALHO, J. A. Lipocalina bovina: quantificação em líquidos corporais de raças bovinas com fenótipos contrastantes de infestações com o carrapato Rhipicephalus microplus, 2016. Dissertação (Mestrado) - Faculdade de Medicina de Ribeirão Preto, Universidade de São Paulo, Ribeirão Preto, 2015.

Rhipicephalus micropulus, conhecido como carrapato dos bovinos, é um dos parasitas mais importantes para a pecuária, pois causa enormes prejuízos ao produtor. Esses prejuízos se estendem desde a ação espoliativa que o carrapato exerce nos seus hospedeiros até a transmissão de uma diversidade de patógenos. Os carrapatos utilizam vários estímulos térmicos, sonoros, visuais, gustativos, táteis e olfativos na fase de busca pelo hospedeiro. Essas substâncias são conhecidas como semioquímicos e podem atuar em indivíduos de uma mesma espécie como os ferormônios ou entre indivíduos de espécies diferentes como os alomônios e cairomônios. Nos bovinos, já se sabe que uma de suas lipocalinas pode atrair insetos, porém não é sabido se essa atração ocorre para $R$. microplus. Já é sabido que o carrapato consegue distinguir odores liberados entre bovinos das raças Nelore e Holandês Preto e Branco (HPB), sendo mais atraído para bovinos da raça Holandês. A lipocalina por ser uma proteína globular e estar associada com o transporte de pequenas moléculas hidrofóbicas, tais como odorantes e esteroides, e pode favorecer a atração do R. microplus, uma vez que essa proteína bovina pode ligar a odorantes e desempenhar um papel fundamental na liberação de odores para o ambiente, que por sua vez pode atrair, ou não, o R. microplus. Existem diferentes níveis de infestação de carrapatos entre bovinos das raças Nelore e Holandês, bem como entre os sexos da mesma raça. Além disso, o período do ciclo de vida do bovino também pode influenciar na susceptibilidade a infestação, por exemplo, as vacas no período de lactação são consideradas mais susceptíveis ao parasito. Assim, o objetivo do presente estudo foi avaliar o papel da lipocalina bovina na resistência e suscetibilidade ao carrapato, através da quantificação dessa proteína em líquidos corporais dos bovinos, tais como soro, saliva, urina, suor, secreção nasal e biopsia de pele obtidos de bovinos que apresentam fenótipos contrastantes de infestações, a saber: hospedeiros macho (touros) e fêmea (vacas em lactação) das raças resistentes (Bos indicus) e suscetíveis (Bos taurus). Os resultados deste trabalho tem demonstrado que a lipocalina bovina está presente em todos os fluídos investigados, exceto a urina, como observado por Western blot. Com os resultados deste trabalho podemos concluir que a bcOBP apresenta 
diferença significativa nos fluidos de saliva e secreção nasal de touros e vacas em lactação da raça HPB quando comparados com touros e vacas em lactação da raça Nelore. Em amostras de biópsia de pele também ocorreu uma maior marcação da bcOBP na raça susceptível (HPB), demonstrando que a bcOBP possivelmente esta auxiliando na susceptibilidade destes bovinos ao carrapato, através do transporte de um maior número de odorantes que estariam atraindo um maior número de carrapatos. Ao analisar os fluidos entre bovinos da mesma raça, porém de sexo diferente, observou-se uma maior quantidade de bcOBP em vacas no período de lactação HPB nos fluidos de saliva e secreção nasal, visto que as vacas estão no período de lactação e são mais susceptíveis a infestações. Consequentemente, a bcOBP poderia estar colaborando para a sua maior susceptibilidade quando comparadas com touros HPB, e o mesmo ocorreu para biopsia de pele. Porém no fluído soro o aumento foi significativo para touro HPB quando comparado às vacas em lactação da raça HPB. Acredita-se que esse fenômeno ocorra devido ao período de lactação nas fêmeas uma vez que a produção da lipocalina bovina esta intimamente relacionada com a produção do leite. Os resultados deste trabalho demonstram que possivelmente a bcOBP na raça HPB está carreando odorantes para o ambiente os quais estariam atraindo mais carrapatos, e auxiliando na susceptibilidade destes bovinos.

Palavras chave: Lipocalina bovina, Rhipicephalus microplus, Resistência e susceptibilidade, proteína de ligação de odorante. 
CARVALHO, J. A. Bovine lipocalin and its role in tick resistance: quantification in body fluids of bovine breeds with contrasting phenotypes of infestations with the tick Rhipicephalus microplus, 2016. Dissertation (Master degree) - Medical School of Ribeirão Preto, University of São Paulo, Ribeirão Preto.

Rhipicephalus micropulus, known as bovine tick, is one of the most important parasites for livestock, as they cause enormous damage to the producer. These demages extend from the spoliation action that the tick exerts on the skin of its hosts until the transmission of a diversity of pathogens. Ticks use various thermal, sound, visual, gustatory, tactile and olfactory stimuli in the search phase to the host. These substances are known as semiochemicals and can act within individuals of the same species as the pheromones or among individuals of different species such as alomones and cairomones. In the cattle, it is known that the lipocalin protein may attract insects, but this attraction is not known to influence the R. microplus. It is known that the tick can distinguish released odors between Nelore and Holstein cattle, being more attracted to cattle of the Holstein breed. Lipocalin, being a globular protein and associated with the transport of small hydrophobic molecules, such as odorants and steroids, can favor the attraction of $R$. microplus, since this bovine protein can bind to odorants and play a key role in the release of odors into the environment, which in turn may or may not attract $R$. microplus. There are different levels of tick infestation among cattle of the Nelore and Holstein breeds, as well as between the sexes of the same breed. In addition, the life cycle period of the bovine can also influence the susceptibility to infestation. For example, cows in the lactation period are considered more susceptible to the parasite. Thus, the objective of the present study was to evaluate the role of bovine lipocalin in the resistance and susceptibility to tick by quantifying that protein in bovine body fluids such as serum, saliva and urine, sweat, nasal secretions and skin biopsies obtained from resistant (Bos indicus) and susceptible (Bos taurus) cattle breeds. The results of this work have demonstrated that bovine lipocalin is present in all investigated fluids except urine, as observed by Western Blot. With the results of this work we can conclude that bcOBP presents a significant difference in fluids saliva and nasal secretion of bulls and cows in lactation breed HPB when compared to bulls and lactating cows of the Nelore breed. In skin biopsy specimens, there was also a greater labeling of bcOBP in the susceptible strain (HPB), which could then aid in the susceptibility of these cattle to the 
tick, by transporting a larger number of odorants that would be attracting a greater number of ticks. When analyzing the fluids between bovines of the same breed, but of different sex, a greater amount of bcOBP was observed in cows during the period of HPB lactation in the fluids saliva and nasal secretion, since the cows are in the lactation period and are more susceptible to infestations. Consequently, bcOBP could be contributing to its greater susceptibility when compared to HPB bulls, and the same was done for skin biopsy. However, in the fluid serum, the increase was significant for the bull when compared to the lactating cows of the HPB race. It is believed that this phenomenon occurs due to the lactation period in females since the production of bovine lipocalin is closely related to milk production. The results of this work demonstrate that possibly Lipocalin in Holstein cattle is carrying odorants to the environment which would be attracting more ticks, and enhancing in the susceptibility of these cattle.

Keywords: Bovine lipocalin, Rhipicephalus microplus, resistance and susceptibility, odorant binding protein. 


\section{LISTA DE FIGURAS}

Figura 1 - Esquema simplificado do ciclo de vida do carrapato Rhipicephalus (Boophilus) microplus . Fase parasitária e fase de vida livre. Adaptado de ANDREOTTI e MALAVARI, 2001

Figura 2 - Fluxograma do delineamento experimental conduzido neste trabalho, vacas em lactacao e touros das racas HPB e Nelore.

Figura 3 - Perfil proteico das amostras de soro total de touros e vacas em lactação das raças HPB e Nelore (SDS-PAGE 12,5\%).

Figura 4 - Perfil proteico das amostras de saliva de vacas em lactação e touros das raças HPB e Nelore (SDS-PAGE 15\%).

Figura 5 - Perfil proteico das amostras de suor de vacas em lactação e touros das raças HPB e Nelore (SDS-PAGE 15\%). 46

Figura 6 - : Perfil proteico das amostras de secreção nasal de vacas em lactação e touros das raças HPB e Nelore (SDS-PAGE 15\%).

Figura 7 -: Perfil proteico das amostras de urina de vacas em lactação e touros das raças HPB e Nelore (SDS-PAGE 15\%). 48

Figura 8 - Curva padrão da recombinante de bcOBP (rbcOBP) usada para quantificação da bcOBP nos diferentes fluídos por meio de densitometria. 49 Figura 09 - Detecção e quantificação de bcOBP por meio de Western Blot e de densitometria de Western Blot de amostras de soro total de vacas em lactação das raças HPB e Nelore. .50

Figura 10 - Detecção e quantificação de bcOBP por meio de Western Blot e de densitometria de Western Blot de amostras soro total de touros raças HPB e Nelore... 51

Figura 11 - Deteç̧ão e quantificação de bcOBP por meio de Western Blot e de densitometria de Western Blot de amostras soro total de touros e vacas da raça HPB.

Figura 12 - Deteç̧ão e quantificação de bcOBP por meio de Western Blot e de densitometria de Western Blot de amostras soro total de touros e vacas em lactação da raça Nelore. 52 
Figura 13 - Detecção e quantificação de bcOBP por meio de Western Blot e de densitometria de Western Blot de amostras de saliva de vacas em lactação das raças HPB e Nelore.

Figura 14 - Detecção e quantificação de bcOBP por meio de Western Blot e de densitometria de Western Blot de amostras saliva de touros raças

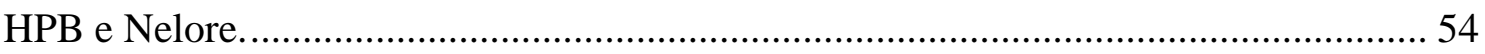

Figura 15 - Detecção e quantificação de bcOBP por meio de Western Blot e de densitometria de Western Blot de amostras saliva de touros e vacas da raça $\mathrm{HPB}$ 55

Figura 16- Detecção e quantificação de bcOBP por meio de Western Blot e de densitometria de Western Blot de amostras de suor de vacas em lactação das raças HPB e Nelore 56

Figura 17 - Detecção e quantificação de bcOBP por meio de Western Blot e de densitometria de Western Blot de amostras suor de touros raças HPB e Nelore.. 57 Figura 18 - Detecção e quantificação de bcOBP por meio de Western Blot e de densitometria de Western blot de amostras suor de touros e vacas da raça HPB 57 Figura 19 - Detecção e quantificação de bcOBP por meio de Western Blot e de densitometria de Western Blot de amostras suor de touros e vacas em lactação da raça Nelore. 58

Figura 20- Detecção e quantificação de bcOBP por meio de Western Blot e de densitometria de Western Blot de amostras de secreção nasal de vacas em lactação das raças HPB e Nelore. 59

Figura 21 - Detecção e quantificação de bcOBP por meio de Western Blot e de densitometria de Western Blot de amostras secreção nasal de touros raças HPB e Nelore

Figura 22 - Detecção e quantificação de bcOBP por meio de Western Blot e de densitometria de Western blot de amostras secreção nasal de touros e vacas da raça HPB..

Figura 23 - Detecção e quantificação de bcOBP por meio de Western Blot e de densitometria de Western Blot de amostras secreção nasal de touros e vacas em lactação da raça Nelore. 
Figura 24- Detecção e quantificação de bcOBP por meio de Western Blot e de densitometria de Western Blot de amostras de urina de vacas em lactação e touros das raças HPB e Nelore.

Figura 25 - Presença da Lipocalina em biópsia de pele de vacas em lactação das raças HPB e Nelore 64 Figura 26 - Presença da Lipocalina em biópsia de pele de touros das raças HPB e Nelore .65

Figura 27- Presença da Lipocalina em biópsia de pele de vacas em lactação e touros da raça HPB.

Figura 28 - Presença da Lipocalina em biópsia de pele de vacas em lactação e touros da raça Nelore 68

Figura 29 - Confirmacao da purificação do anticorpo IgY anti lipocalin, e confirmação do reconhecimento das amostras coletadas (saliva e secreção nasal) e confirmação que não ocorre interação entre IgM e IgY 


\section{LISTA DE TABELAS}

Tabela 1 - Lipocalinas presente em bovinos utilizadas para o alinhamento através do site uniprot para escolha do peptídeo.

69

Tabela 2 - Alinhamento de todas as sequências das lipocalinas presente em bovinos para escolha do peptideo. 


\section{LISTA DE ABREVIATURAS E SIGLAS}

R. Microplus - Rhipicephalus (Boophilus) microplus

SCRs - Structurally Conserved Regions

OBPs- Odorant Binding Protein

bOBP- Bovine odorant binding proteins

bcOBP- Lipocalina bovina ( bovine colostral odorant-binding protein )

SDS-PAGE - gel de poliacrilamida

$\operatorname{Ig} \mathrm{Y}$ - imunoglobulina de galinha

HPB- Holandês Preto e Branco

NEL - Nelore

rbcOBP- recombinante da lipocalina bovina (bovine colostral odorant-binding protein)

NEL-macho - Nelore macho

NEL- fêmea - Nelore fêmea (vacas em lactação)

HPB-macho - Holandês macho

HPB- fêmea - Holandês fêmea (vacas em lactação)

Tampão fosfato salina (PBS)

$1 \mathrm{D}$ - uma dimensão

HCL- Ácido clorídrico

mA- mil amperagem

V - Volts

IgM - imunoglobulina $\mathrm{M}$

HRP- Horseradish peroxidase

BSA- Albumina do soro bovina

DAB - diaminobenzidina

DP- desvio padrão

MPM- peso molecular

D.O - densidade ótica

MUPs - major urinary proteins

fig. - Figura (as) 


\section{SUMÁRIO}

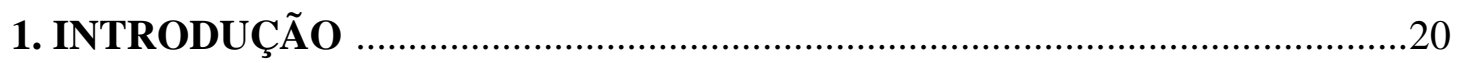

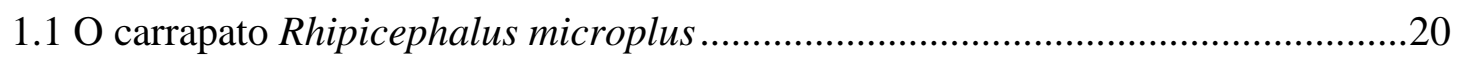

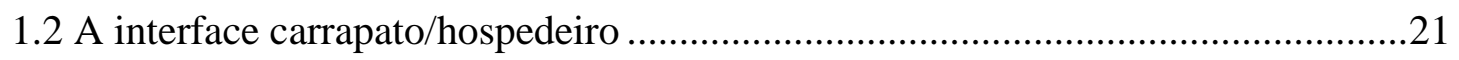

1.3 Resistencia e Susceptibilidade a Carrapatos ......................................................24

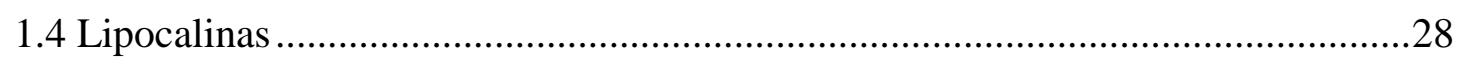

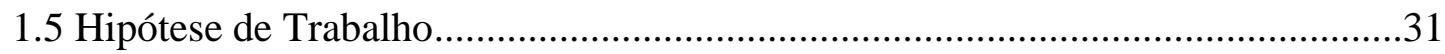

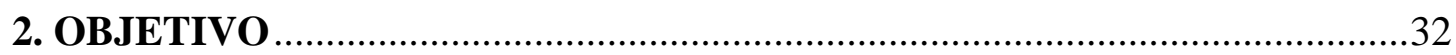

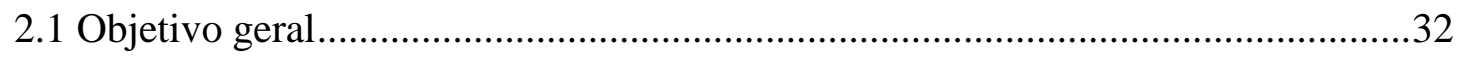

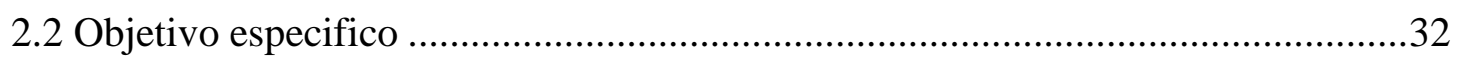

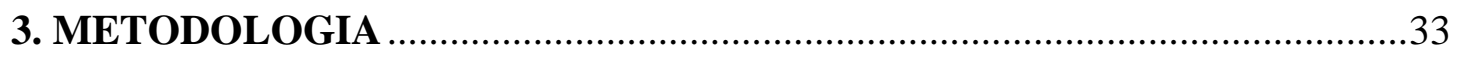

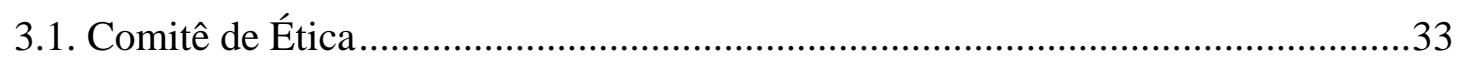

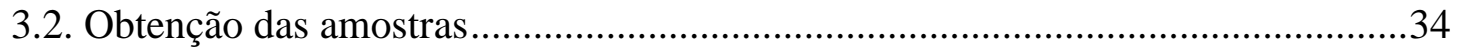

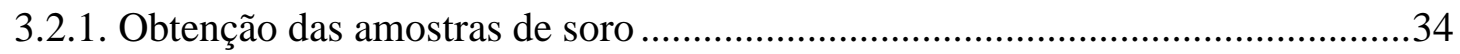

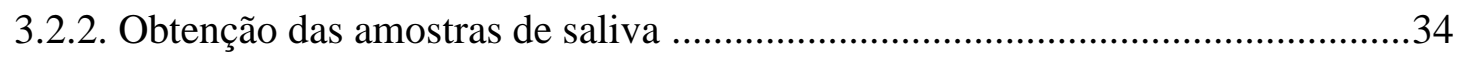

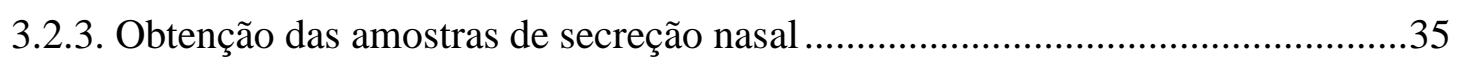

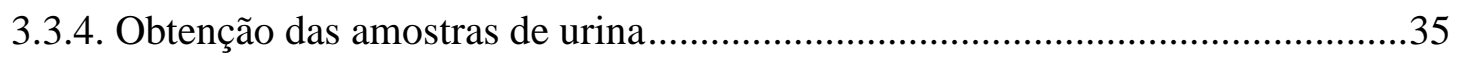

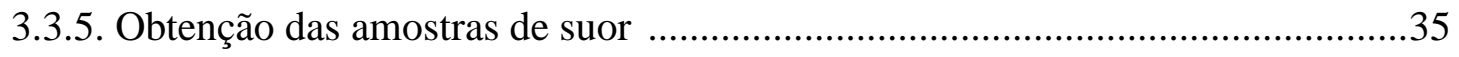

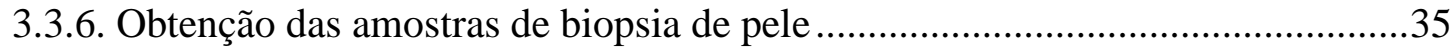

3.3. Quantificação das proteínas totais em todos os fluidos corpóreos coletados ........36

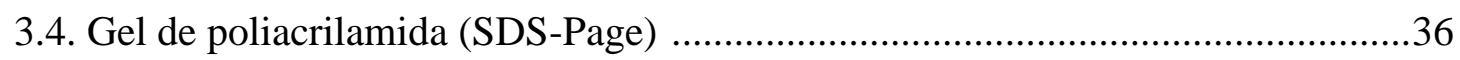

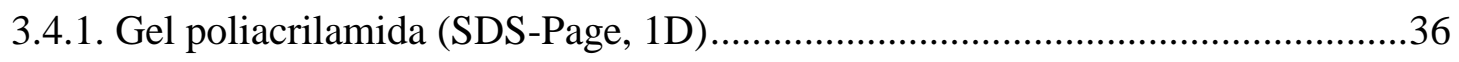

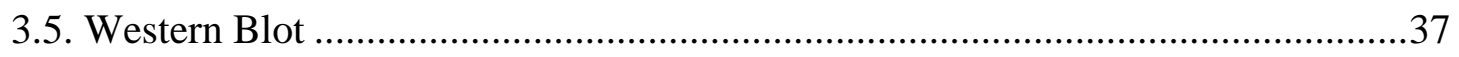

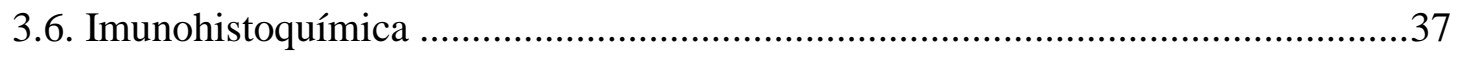

3.7. Escolha de peptídeo para produção de anticorpo policlonal em galinha (IgY) ...38

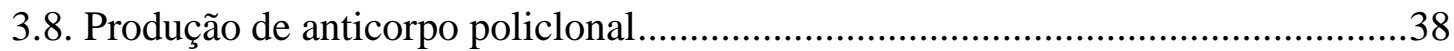

3.8.1. Purificação do anticorpo policlonal anti-lipocalina bovina (IgY anti

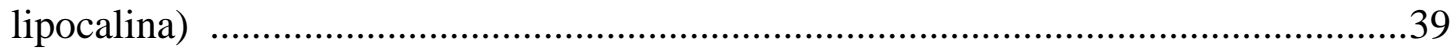

3.8.1.1. Dosagem proteica do anticorpo policlonal anti-lipocalina bovina (IgY antilipocalina) pelo método de Bradford .................................................................... 40

3.8.1.2. Avaliação da pureza do anticorpo policlonal anti- lipocalina bovina (IgY antilipocalina) 
3.8.1.3. Avaliação da atividade do anticorpo policlonal anti- Lipocalina Bovina ( $\operatorname{Ig} Y$

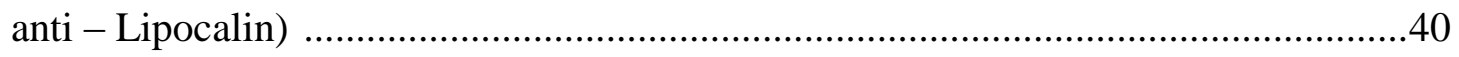

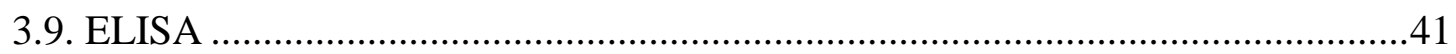

3.9.1. ELISA usando $\operatorname{IgM}$ anti lipocalin como anticorpo primário, $\operatorname{IgY}$ como

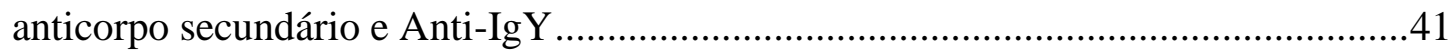

3.9.2. ELISA usando $\operatorname{IgY}$ anti lipocalin como anticorpo primário, $\operatorname{IgM}$ como

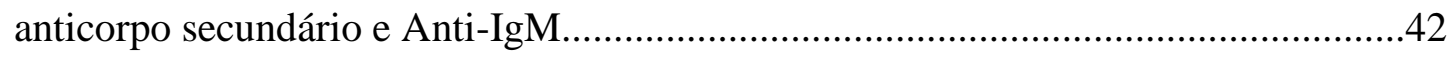

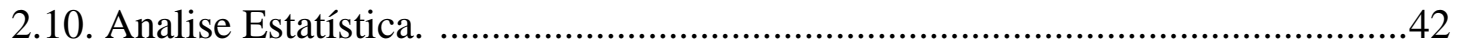

4. RESULTADOS

4.1. Presença da Lipocalina bovina nos diferentes fluídos. .......................................43

4.2. Confirmação da presença e análise semi-quantitativa da Lipocalina bovina (bcOBP) nos diferentes fluidos corpóreos entre bovinos de ambas as raças e sexo... 49

4.2.1. Presença e analise semi-quantitativa de Western Blot da lipocalina bovina (bcOBP) em amostras de soro total coletado de bovinos Holandês e Nelore (macho e fêmeas em lactação)

4.2.2. Presença e analise semi-quantitativa de Western Blot da lipocalina bovina (bcOBP) em amostras de suor coletado de bovinos Holandês e Nelore (macho e fêmeas em lactação)

4.2.3. Presença e análise semi-quantitativa de Western Blot da lipocalina bovina (bcOBP) em amostras de urina coletada de bovinos Holandês e Nelore (macho e fêmeas em lactação).

4.2.4. Presença e análise semi-quantitativa de Western Blot da lipocalina bovina (bcOBP) em amostras de saliva coletada de bovinos Holandês e Nelore (macho e fêmeas em lactação).

4.2.5. Presença e análise semi-quantitativa de Western Blot da lipocalina bovina (bcOBP) em amostras de secreção nasal coletada de bovinos Holandês e Nelore (macho e fêmeas em lactação)

4.3. Avaliação da presença da lipocalina bovina (bcOBP) em pele de bovinos de ambas as raças (Holandês e Nelore) e sexo (macho e fêmea) por imuno-histoquímica.

4.4. Produção do anticorpo policlonal anti-lipocalina (IgY anti-lipocalin)

4.4.1. Peptídeo escolhido para imunização da galinha

4.4.2. Confirmação da produção do anticorpo e o reconhecimento do peptídeo imunizado e o reconhecimento da lipocalina bovina em amostras coletadas . .70 
5. DISCUSSÃ̃

.73

6. CONCLUSÃO

.78

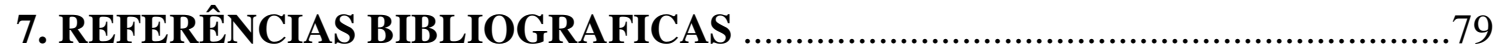




\section{INTRODUÇÃO}

\subsection{O carrapato Rhipicephalus microplus}

O carrapato Rhiphicephalus microplus pertence ao filo Arthropoda, classe Arachnida, ordem Acarina, subordem Metastigmata e superfamília Ixodidae (Flechtmann, 1990). Atualmente pertence ao gênero Rhipicephalus devido a estudos moleculares e morfológicos os quais demostraram uma relação filogenética entre Rhipicephalus e Boophilus (Murrell and Barker, 2003)

A espécie Rhiphicephalis (Boophilus) microplus provavelmente originou-se da Ásia, adaptando-se muito bem ao clima das áreas tropicais, que apresentam calor e umidade em condições favoráveis à sobrevivência e manutenção da espécie (Powwl; Reid, 1982) É amplamente distribuído por todo o país, variando a intensidade de acordo com as condições climáticas e os tipos raciais de bovinos explorados (Gonzales, 1995)

Carrapatos são ectoparasitas hematófagos obrigatórios, os quais transmitem patógenos que prejudicam a saúde pública e animal. O carrapato $R$. microplus parasita preferencialmente o gado bovino e suas infestações exercem efeitos adversos sobre o hospedeiro ( De la Fuente et al., 1999; Piper et al., 2009)

Popularmente conhecido como "carrapato-do-boi", leva a perdas econômicas e sanitárias na produção de leite, carne e couro, pois espolia o hospedeiro e provoca danos no couro causados por reações inflamatórias nos locais de sua fixação. Além disso, facilita a transmissão de doenças, como a tristeza parasitária bovina (TPB) que pode ser causada por hemoprotozoários do gênero Babesia e pela bactéria do gênero Anaplasma (Andreotti, 2010).

Esses ectoparasitas apresentam poucos inimigos naturais e os métodos tradicionais de controle de carrapatos são o uso de produtos químicos, que alcançam resultados parcialmente satisfatórios. Esse método possui alguns inconvenientes, tais como o aparecimento de carrapatos resistentes a diversos acaricidas devido ao uso contínuo, a contaminação ambiental e problemas de resíduos como, por exemplo, a contaminação da carne. Com isso uma solução mais direta e sustentável para o controle de infestações é necessário (De la Fuente et al, 1999; Piper et al., 2009; Rodriguez et al., 1995). 
O ciclo de vida do carrapato $R$. Microplus divide-se em uma fase de vida livre e uma fase parasitária (Figura 1). A fase de vida livre se inicia após a queda da teleógina ingurgitada, e dura em média de dois a três dias. Posteriormente inicia-se a fase de ovipostura, cuja duração gira em torno de 17 dias e é seguida da fase de eclosão, cuja duração pode ser de cinco a dez dias, podendo, no entanto, durar até mais de 100 dias. Após a eclosão das larvas a fase parasitária inicia-se quando a larva infestante se instala no hospedeiro durando em torno de 21 dias (Gonzales, 1975).

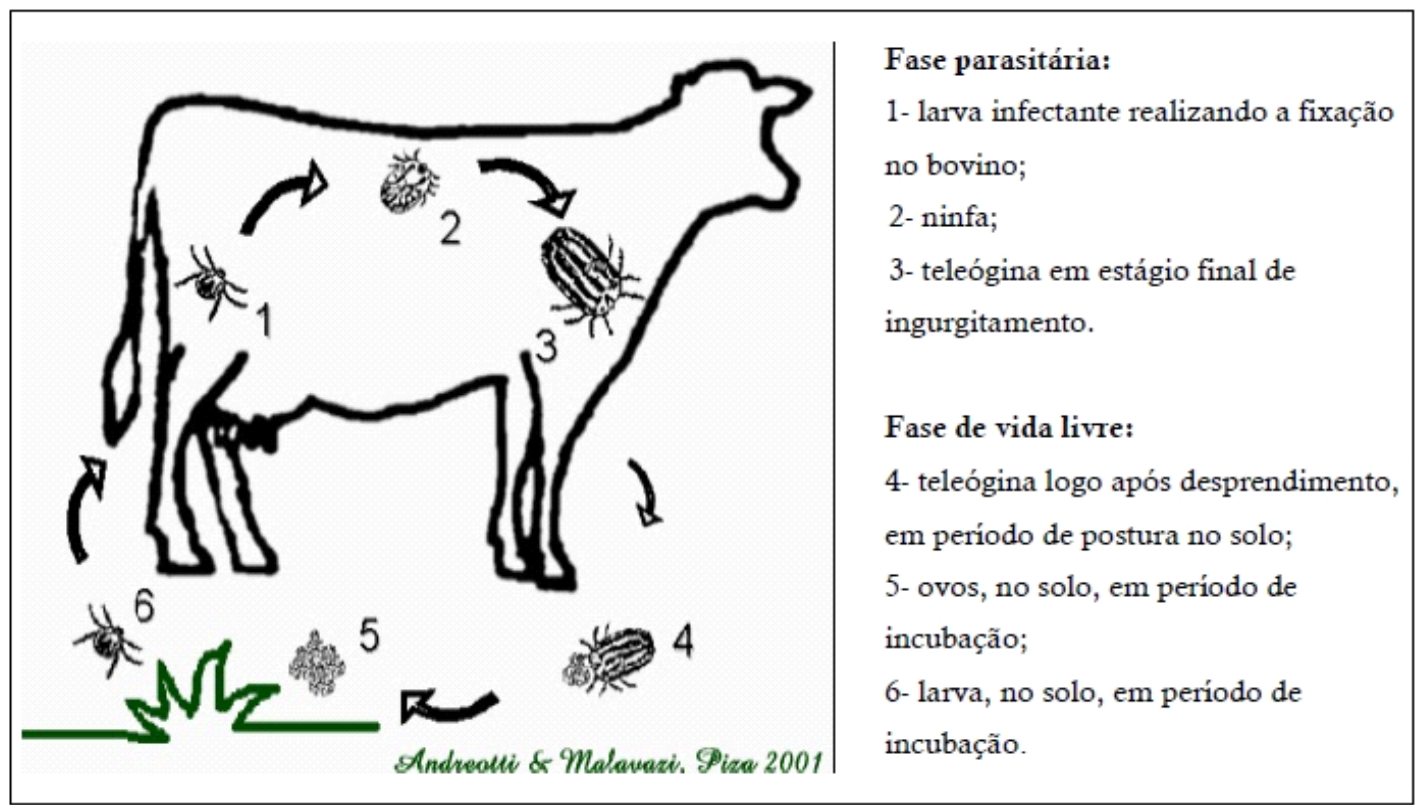

Figura 1 - Esquema simplificado do ciclo de vida do carrapato Rhipicephalus (Boophilus) microplus. Fase parasitária e fase de vida livre. Adaptado de Andreotti e Malacari, 2001).

\subsection{A interface carrapato/hospedeiro}

O sucesso da relação parasito-hospedeiro é um balanço entre as limitações do parasito pelas defesas do hospedeiro e a habilidade do parasito em modular, evadir ou restringir a resposta imune (Wikel, 1996). A interação entre carrapato e hospedeiro depende das condições apresentadas pelos animais, ocasionando assim uma variação entre os efeitos parasitários dos animais como a simples irritação na pele até a morte do hospedeiro (Arthur, 1973). Entretanto, algumas relações da interação entre o parasito e o hospedeiro são caracterizadas pela aquisição de resistência depois de repetidas 
infestações (Wikel\& Bergaman, 1997). Uma grande quantidade de vertebrados conseguiu desenvolver a habilidade de resistir a repetidos ataques por carrapatos. Entretanto, são incapazes de resistir ao desafio inicial, logo desenvolvem uma resposta imune efetiva quando desafiados novamente, resultando em uma imunidade adquirida para mais ataques de carrapatos. Tal fato reflete então na habilidade que o hospedeiro vertebrado desenvolveu para reconhecer e se proteger contra danos, substâncias e organismos estranhos (Soneshine, 1993).

A larva infestante, quando entra em contato com o hospedeiro, busca fixar-se em regiões de seu corpo as quais beneficiam seu desenvolvimento, tais como: úbere, mamas, regiões do períneo, vulva e entre as pernas. Essas regiões preferenciais de fixação são determinadas em função da espessura da pele, vascularização e temperatura, bem como pela dificuldade de acesso às lambidas do hospedeiro (Wagland, 1978).

Para completar a sua alimentação de sangue o Rhipicephalus (Boophilus) microplus permanece em seu hospedeiro por vários dias. O desafio para o sistema imunológico começa no momento em que os aparelhos bucais do carrapato são inseridos na pele, provocando o rompimento dessa barreira física, causando tanto dano físico como químico. As primeiras células presentes nesse contato são leucócitos residentes na epiderme e derme, como mastócitos, eosinófilos, células dendríticas e macrófagos. Estas células liberam mediadores, além de produzir fatores quimiotáticos para recrutar células inflamatórias, como neutrófilos, para o local de fixação do carrapato (Francischetti et al., 2010).

Os carrapatos utilizam vários estímulos na fase de busca pelo hospedeiro, entre eles os térmicos, sonoros, visuais, olfativos, gustativos e táteis (Wallade, Rice,1977). Diferentemente de outros sinais, os compostos químicos voláteis são facilmente dispersados pelo vento por grandes distâncias, podendo ainda permanecer por maiores períodos de tempo e fornecendo informação segura da direção da fonte emissora de estímulo (Guerrin et al., 2000; Ferreira, 2001; Vilella \& Della Lúcia, 2001). Assim sendo, os carrapatos direcionam seu comportamento principalmente em função de estímulos químicos (Sonenhine, 2004). Para tanto utilizam os órgãos sensoriais que são adaptados para essa função, como o órgão de Haller e palpos maxilares. Estes órgãos são dotados por sensilas, as quais são receptores celulares onde os carrapatos detectam os estímulos ambientais (Sonenshine, 1991; Guerin et al., 2000). A maioria das espécies de carrapato não possuem olhos propriamente ditos, e mesmo para aqueles que 
apresentam olhos existem dúvidas se enxergam formas definidas ou discriminem objetos (Soneshine, 1991).

O órgão de maior importância para a percepção sensorial dos carrapatos é o órgão de Haller, encontrado em todas as espécies de carrapatos e está localizado no dorso do tarso no primeiro par de patas (Soneshine, 1991; Soneshine, 2004; Fabbro \& Nazzi, 2013). A função deste órgão é a olfatação, uma vez que apresenta o maior número de quimiosensilas, mas ainda apresenta mecanossensilas e termohigrossensilas. Quimiossensilas são divididas em olfativas e gustativas. As sensilas olfativas são as responsáveis pela percepção de compostos químicos voláteis com gás carbônico. Já as gustativas são especializadas em perceber compostos químicos encontrados em soluções como cloreto de potássio $(\mathrm{KCl})$ e cloreto de sódio $(\mathrm{NaCl})$ (Wallade \& Rice, 1977; Sonenhine, 1991; Ferreira, 2013; Soares et al., 2013). O número e o tipo de sensilas variam entre as espécies de carrapatos (Soneshine, 1991).

Os compostos químicos orgânicos voláteis (COV) apresentam um papel de grande importância na ecologia de artrópodes, principalmente daqueles cujos hábitos são terrestres, como os carrapatos (Villela \& Della Lúcia, 2001; Sonenshine, 2004).

COV podem ser liberadas pelo hospedeiro, podendo atuar na fase de busca do carrapato até seu hospedeiro, e são considerados bons condutores de sinais liberados no ambiente para carrapatos (Waladde, 1982; Waladde \& Rice, 1982; Steullet \& Guerin, 1994; Carroll, 1998, 1999; Osterkamp et al., 1999). Estes animais não dispõem de uma grande disseminação devido a sua ecologia, exceto durante a fase parasitária quando podem ser carregados por longas distâncias pelos seus hospedeiros (Labruna \& Pereira, 2001; Szabó et al., 2012). Os COV podem desencadear em carrapatos comportamentos como alimentação, oviposição, acasalamento, agregação, interrupção de hábitos alimentares, disseminação entre outros (Villela \& Della Lúcia, 2001; Sonenshine, 2004; Logan \& Birkett, 2007; Pickett et al.2010).

Substâncias químicas são utilizadas por animais como uma forma de comunicação intra e interespecífica. Essas substâncias são conhecidas como semioquímicos e podem atuar dentro de indivíduos de uma mesma espécie como os ferormônios, ou entre indivíduos de espécies diferentes como os alomônios e cairomônios (Vilella, Della Lúcia, 2001). Os cairomônios podem servir como sinalizadores para o carrapato tanto da presença do hospedeiro, como de um local no meio ambiente no qual seja mais provável o encontro do mesmo (Carroll, 1999). 
Componentes da urina, moléculas liberadas pela respiração ou substâncias encontradas na pele dos animais foram demonstradas como sendo atrativas para espécies de carrapatos (Carroll, 1999; Osterkamp et al., 1999); Macmahon, Guerin, 2002). Em geral, o hospedeiro é localizado pelo odor, pelas vibrações, pelo sombreamento, pelo estímulo visual e pela concentração de $\mathrm{CO}^{2}$ (Sonenshine, 1993)

\subsection{Resistência e Susceptibilidade a Carrapatos}

Os bovinos são hospedeiros naturais do carrapato $R$. microplus e constituem o único modelo no qual é possível examinar, numa mesma espécie, os desfechos distintos de resistência e susceptibilidade das infestações com esse parasita. Ainda existem dúvidas sobre quais seriam os mecanismos responsáveis por esses desfechos distintos, mas a composição da saliva dos carrapatos indica que a resposta imune é um deles (Santos et al., 2009). Ainda em relação a bovinos, a maioria dos estudos sobre aquisição de resistência avalia o fenômeno em raças taurinas que, embora desenvolvam imunidade, não controlam as infestações com a mesma eficiência das raças zebuínas (Mattioli \& Cassma, 1995; Wambura et al., 1998; Mattioli et al., 2000).

Entre os bovinos existem raças resistentes (Bos taurus indicus) e suscetíveis (Bos taurus taurus) ao parasita, sendo herdável o fenótipo da infestação (Mattioli, 1998). Apesar de décadas de intensos estudos sobre a resistência dos B. t. indicus e B. $t$. taurus os mecanismos continuam pouco entendidos (Constantinoiu et al., 2010).

As raças indianas são mais resistentes ao carrapato que as raças taurinas, embora se saiba que a expressão de resistência a carrapato pode ser afetada por vários fatores como sexo, idade, nutrição e estação do ano (Wambura et al., 1998).

Vários autores demonstraram a influência dos fatores sazonais no ciclo de vida dos carrapatos e, consequentemente a diferença de infestações nos animais, que variam de acordo com o clima da região em que vivem e com a época do ano (da Rocha, online; Madalena et al., 1985; Oliveira et al., 1989). A fase de vida livre é bastante influenciada, principalmente pela temperatura e umidade (Gonzales, 1975).

A resistência ao carrapato ocorre em duas fases, sendo elas a resistência inata e a resistência adquirida e estão presentes em raças resistentes e suscetíveis, embora com formas e manifestações diferentes. A resistência inata é caracterizada pelo primeiro contato do animal com o carrapato, já a resistência adquirida é formada por meio da 
resposta do sistema imunológico do hospedeiro após sucessivas infestações por carrapatos, envolvendo, então, a imunidade celular e humoral (Wikel, 1996).

A estrutura física da pele é a primeira linha de defesa contra ectoparasitas, pois o pêlo dos bovinos é revestido por uma mistura de suor e sebo que participa da barreira que dificulta a fixação do carrapato no hospedeiro (Kongsuwan et al., 2010).

O nível das infestações causadas pelo carrapato $R$. microplus varia de acordo com as raças de seus hospedeiros, gados de origem europeia são menos resistentes ao carrapato em relação ao gado indiano mesmo após repetitivas infestações (Wambura, et al., 1998).

As fêmeas são mais resistentes ao carrapato que os machos, tanto em infestações artificiais como em infestações naturais; e no final da gestação, e durante a lactação, as vacas podem ficar mais suscetíveis ao carrapato, devido, possivelmente, à interferência de hormônios sexuais sobre a imunidade do animal (Veríssimo, 1993). A suscetibilidade de bovinos europeus e mestiços aumenta durante o outono, devido ao encurtamento do foto período (Sutherst et al., 1983). No período do inverno as infestações tendem a diminuir devido ao clima frio, prejudicando a fase de vida livre do parasita (Veríssimo et al., 1995).

Os bovinos são hospedeiros naturais do carrapato $R$. microplus e constituem o único modelo no qual é possível examinar, numa mesma espécie, os desfechos distintos de resistência e susceptibilidade das infestações com esse parasita. (Mattioli, 1998; Mattioli e Cassma, 1995; Mattioli et al., 2000; Wamdura et al., 1998). Vários autores demonstraram que existe uma maior resistência ao carrapato $R$. microplus em bovinos zebuínos quando comparados com bovinos taurinos (Gonzales, 1975; Utech et al, 1978; Madalena et al, 1985; Oliveira e Alencar, 1989 e 1990; Villares, 1941).

Zebuínos apresentam um maior número de glândulas sebáceas na pele e, conforme predito pela hipótese da fermentação (Albone et al., 1974), poderiam produzir odores os quais afastariam o carrapato. A pele de zebuínos também apresenta maior mobilidade e elasticidade, possivelmente fazendo com que se defenda melhor das infestações (Gonzales, 1975).

A saliva de carrapato contém moléculas que são inoculadas no local de fixação nos seus hospedeiros de modo a modular as respostas imunes locais e facilitar uma refeição de sangue bem sucedida. Saliva de carrapato pode conter moléculas que interferem com a adesão de leucócitos ao endotélio e hospedeiros resistentes podem 
montar um perfil inflamatório que é mais eficiente para dificultar a refeição sanguínea do carrapato. Bovinos das raças resistentes e susceptíveis foram submetidos à baixa e alta infestação por carrapato, estudos histológicos demonstraram que as reações cutâneas de hospedeiros resistentes a mordidas de carrapatos adultos continham significativamente mais basófilos e eosinófilos em comparação com as reações da raça suscetível. A expressão das moléculas de adesão - molécula de adesão intercelular-1 (ICAM-1), molécula de adesão celular vascular 1 (VCAM-1) e P-selectina - foi maior na pele infestada por adultos de hospedeiros suscetíveis submetidos a infestações baixas em comparação com hospedeiros resistentes; Quando o hospedeiro foi exposto a infestações elevadas a expressão destas moléculas de adesão foi regulada para baixo em ambos os fenótipos de infestações. A expressão da glicoproteína-1 de adesão de leucócitos (LFA-1) foi maior na pele de hospedeiros susceptíveis submetidos a infestações baixas ou elevadas em comparação com hospedeiros resistentes. Por outro lado, níveis mais elevados de E-selectina, que promove a adesão de células $\mathrm{T}$ de memória, foram expressos na pele de animais resistentes. Este achado pode explicar a capacidade do hospedeiro resistente de montar respostas secundárias mais rápidas e eficientes que limitam a hematófagos e infestações. Os perfis de expressão observados para moléculas de adesão indicam que há diferenças na cinética das reações inflamatórias montadas por hospedeiros resistentes e suscetíveis e o equilíbrio entre carrapato e hospedeiro é afetado pelo número de picadas de carrapatos recebidas por um hospedeiro. Demonstraram que os fenótipos contrastantes de infestações observados em bovinos infestados com $R$. microplus estão correlacionados com diferenças na composição celular e molecular de infiltrados inflamatórios provocados por mordidas de carrapatos (Carvalho et al., 2010).

Os animais usam sua língua para autolimpeza, um comportamento importante para se livrar de ectoparasitas. No entanto, o papel da morfologia da língua, notadamente as papilas filiformes, neste processo é pouco conhecido. Este estudo comparou características das papilas filiformes de línguas em Nelore, HPB e Brown Swiss e como elas se associam com a carga de carrapato. Os resultados demonstraram que Nelores apresentam papilas mais longas e mais papilas por $\mathrm{cm}^{2}$ que os bovinos europeus. Concluindo que o espaçamento entre papilas é menor em Nelores, portanto, suas línguas podem ser mais ásperas e consequentemente, mais eficazes na remoção de 
larvas de carrapatos durante a autolimpeza, explicando então a maior resistência. (Veríssimo et al., 2015)

Bovinos suscetíveis não apresentam sinais de lesão na pele, enquanto animais resistentes apresentam dermatite caracterizada por alopecia, hemorragia, crostas e fissuras (Contantinoiu, et al., 2010).

Franzin e colegas (2016, noprelo) demonstraram que ao avaliar o perfil gênico de bovinos resistente e susceptíveis a infestação por $R$. microplus nos diferentes estágios de infestação (larva e ninfa), ocorre reações inflamatórias ao redor do cone de cimento permite a ligação em ambas as raças, porém em bovinos geneticamente resistentes os carrapatos desestabilizaram o cone de cimento. Os dados de transcrição forneceram compreensão sobre a ativação de basófilos mediada por carrapatos, os quais anteriormente demonstraram ser uma chave para a resistência do hospedeiro em sistemas de modelos. A pele de bovinos suscetíveis a carrapatos expressou mais transcritos que codificam enzimas que desintoxicam tecidos. Curiosamente, essas enzimas também produzem compostos odoríferos voláteis e, consequentemente, os esfregaços cutâneos de bovinos suscetíveis atraíram significativamente mais larvas de carrapatos do que os esfregaços de hospedeiros resistentes. Além disso, os transcritos que codificam moléculas moduladoras segregadas pelo carrapato foram significativamente mais abundantes nas larvas e nas glândulas salivares da ninfa a partir de carrapatos que se alimentam de bovinos susceptíveis. O que permite concluir que compostos voláteis exibem expressão significativamente menor em hospedeiros resistentes, o que pode torná-los menos atraentes para as larvas.

Ferreira e colegas (2015) demonstraram que carrapatos adultos conseguem distinguir diferença de odor entre bovinos resistentes e susceptíveis. O R. microplus expressa de forma diferente o comportamento de questing (comportamento que o carrapato apresenta a procura de seu hospedeiro) dependendo do odor da raça de bovino percebido. Esse comportamento pode ajudar a evitar que o carrapato parasite bovinos da raça Nelore, o que é biologicamente mais vantajoso para o carrapato, uma vez que o carrapato alimentado em bovinos da raça Nelore apresenta seu desenvolvimento comprometido. Além disso, as larvas respondem com mais movimentos de questing diante de odores de HPB quando comparadas a larvas expostas a odores de Nelores.

Ainda é pouco conhecido como os carrapatos conseguem distinguir odores liberados por seus hospedeiros resistentes e suscetíveis. Já é descrito que existe uma 
família de proteínas chamadas de Lipocalinas, que apresenta diversas funções, dentre elas transportarem pequenas moléculas hidrofóbicas, tais como odorantes. Lipocalinas fornecem uma ligação entre os sinais químicos do ambiente e os receptores de odorantes, que estão localizados na estrutura de um animal, seja invertebrado ou vertebrado. Essas proteínas podem estar envolvidas no transporte de odorantes de seus hospedeiros, tais odorantes podem ser liberados para o ambiente, podendo, então, auxiliar na atração ou repelência do hospedeiro para o carrapato.

\subsection{Lipocalinas}

Lipocalinas sãoproteínas extracelulares de baixo peso molecular, e constituem uma família com um grande número de representantes e que são encontradas em diversos organismos, sendo eles vertebrados, invertebrados, plantas e bactérias. Esse grupamento e o nome, para designá-lo, lipocalinas, foi originalmente proposto por Syed Pervaiz e Keith Brew (Pervaiz e Brew, 1985) para refletir sua capacidade de ligar pequenas moléculas lipofílicas dentro de uma estrutura caliciforme que minimiza o contato dessas com o solvente.

Lipocalinas constituem, portanto, uma família de proteínas onde os membros apresentam estruturas terciárias altamente conservadas, enquanto as suas sequências de aminoácidos são amplamente diversificadas (Akerstrom et al., 2000). Lipocalinas são

proteínas globulares pequenas com peso molecular de aproximadamente 20kDa, e muitas vezes são capazes de incorporar compostos apolares em sua cavidade hidrofóbica dentro de um núcleo folha beta com oito cadeias antiparalelas (Akerstrom et al., 2000; Flower et al., 2000).

As principais propriedades das lipocalinas são: 1) se ligam a moléculas hidrofóbicas de baixo peso molecular; 2) se ligam a receptores de membrana celular e a outras proteínas, podendo formar complexos macromoleculares; 3) apresentam estrutura terciária na forma de um $\beta$-barril, formado por oito folhas $\beta$ antiparalelas mantidas por pontes de hidrogênio e um sítio de ligação na cavidade central, onde se ligam as moléculas a serem transportadas (Flower, 1996; Grzyb et al., 2006).

As Lipocalinas apesar de apresentarem estrutura secundária e terciária altamente conservada, em geral, possuem baixa similaridade na sequência de aminoácidos (10 a $20 \%$ ). Contudo, observa-se a presença de três domínios conservados na sequência 
primária destas proteínas, denominados regiões estruturalmente conservadas (do inglês, structurally conserved regions-SCRs). As regiões estruturalmente conservadas são classificas em domínios SCR1, SCR2 e SCR3. As proteínas que apresentam estes três domínios característicos de lipocalinas são classificadas no grupo kernel, que inclui a maioria das lipocalinas. Em um segundo grupo, denominado outlier, são incluídas as Lipocalinas com maior divergência. Lipocalinas do grupo outlier apresentam apenas um ou dois desses domínios, com mais frequência o SCR1, enquanto o SCR2 é encontrado exclusivamente em lipocalinas do grupo kernel (Flower et al., 1993).

Dentre os membros da família das Lipocalinas estão as proteínas ligantes de odorantes ou, do inglês, Odorant Binding Protein (OBPs) que fornecem uma ligação entre os sinais químicos do ambiente e os receptores de odorantes, que estão localizados na estrutura olfativa no sistema sensorial periférico em animais (Yu et al., 2009).

OBPs foram encontradas em uma variedade de mamíferos na camada da mucosa, onde se ligam a odores e de alguma forma influenciam o estágio inicial do olfato (Pelosi, 2001). OBPs também foram identificadas em fluidos biológicos e mucosa nasal. Em porcos, as OBP foram identificadas como proteínas que ligam especificamente ferormônios maternos em fluidos corpóreos tais como colostro, leite maduro e fluídos amnióticos (Guiraudie-Capraz et al., 2005).

A primeira OBP identificada em mamíferos foi a bovina, isolada a partir da mucosa nasal (Bignetti et al., 1985; Pevsner et al., 1985). A proteína odorante bovina (em inglês Bovine odorant binding proteins, bOBP) primeiramente despertou atenção porque aparentemente tem a função de carregar moléculas hidrofóbicas de odorantes e por iniciar um papel chave no olfato (Pelosi, 2001).

Foi descoberta uma OBP no colostro bovino, chamada de bovine colostral odorant-binding protein (bcOBP). Mais estudos demonstraram a presença da bcOBP em vários fluídos dentre eles a mucosa nasal, saliva, fluido amniótico, corrimento vaginal e plasma sanguíneo a partir de vacas em lactação (Japaridze et al., 2012)

A bcOBP consiste em 172 resíduos de aminoácidos com uma sequência sinal putativa 16-amino-ácido, apresentando peso molecular de aproximadamente 19kDa, e exibindo semelhança com outras proteínas da família da Lipocalina, sendo sua semelhança na sequência de $83 \%$ com a Bos d2 (uma Lipocalina que é alérgeno), considerada uma semelhança elevada. E também apresenta uma semelhança de $52 \%$ com a bOBP, portanto, apresentando uma semelhança moderada. A proteína bOBP é 
encontrada em grande quantidade na mucosa nasal bovina (Fukuda et al., 2009).

A proteína bOBP é capaz de carrear odorantes, como 1-octen-3-ol o qual é uma substância volátil e é um componente natural de respiração bovina e, em geral, é liberado pelo corpo de animais. O composto 1-octen-3-ol é também é um potente atrativo para muitas espécies de insetos, incluindo alguns vetores como Anopheles (vetor dos parasitas do gênero Plasmodium) ou Glossina (vetor de parasitas do gênero Trypanosoma). Visto que esse composto pode auxiliar na atração de insetos, haveria um possível papel de bOBP nas relações ecológicas entre as espécies bovina e artrópodes hematófagos (Ramoni et al., 2001).

McMahon e colegas (2001) foram os primeiros a relatar que o composto 1-octen-3-ol atua como atraente para carrapatos E, como dito acima, é caracteristicamente encontrado em odores bovinos e provoca uma significativa resposta de atração para o carrapato R. microplus (Osterkamp et al., 1999).

Visto que o carrapato utiliza vários estímulos térmicos, sonoros, visuais, olfativos, gustativos e táteis na fase de busca pelo hospedeiro, que a lipocalina fornece uma ligação entre os sinais químicos do ambiente e os receptores de odorantes e que existem diferenças nas cargas de carrapatos que diferentes raças bovinas carregam, a expressão da bcOBP em fluidos corpóreos pode diferir entre essas raças resistentes ou susceptíveis ao $R$. microplus. Essas proteínas poderiam estar envolvidas no transporte de odorantes de seus hospedeiros, tais odorantes seriam liberados para o ambiente e estariam auxiliando na atração ou repelência do carrapato na fase de busca pelo seu hospedeiro. 


\subsection{Hipótese de Trabalho.}

A lipocalina bovina (bcOBP) pode estar em diferentes quantidades em bovinos das raças Nelore e HPB auxiliando na repelência ou atração do carrapato $R$. microplus. 


\section{OBJETIVOS}

\subsection{Objetivos gerais}

- Verificar se os níveis de bcOBP diferem entre bovinos de raças geneticamente resistentes e susceptíveis ao carrapato $R$. microplus.

\subsection{Objetivos específicos:}

- Coletar amostras de soro, secreção nasal, suor, urina, saliva e biópsias de pele de bovinos das raças Nelore e Holandês Preto e Branco, resistentes e susceptíveis a infestações com $R$. microplus, respectivamente.

- $\quad$ Detectar a presença da bcOBP nessas amostras desses bovinos.

- $\quad$ Por meio de ensaios imuno-enzimáticos quantificar a bcOBP nessas amostras desses hospedeiros. 


\section{Metodologia}

\subsection{Comitê de Ética}

O projeto seguiu as normas da Comissão de Ética do Instituto de Zootecnia - IZ de Nova Odessa e a Comissão de Ética da Universidade do Estado de São PauloCampus Pirassununga, tendo sido devidamente aprovado para o uso de touros e vacas em lactação das raças Nelore e Holandês (HPB) (certificado 201500001). Um fluxograma do delineamento experimental do projeto está representado na Figura 1.

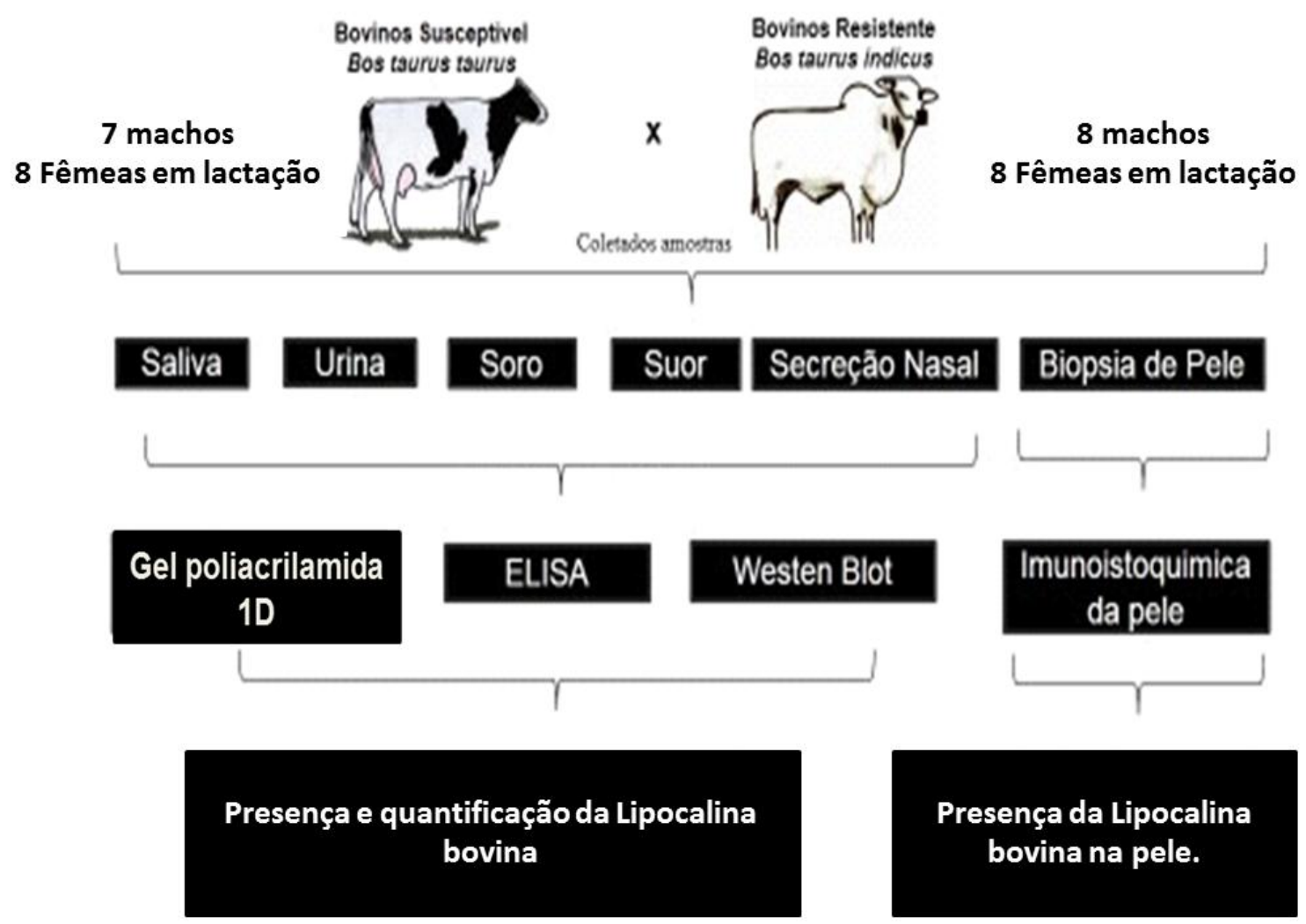

Figura 02: Fluxograma do delineamento experimental experimental conduzido neste trabalho, vacas em lactação e touros das raças HPB e Nelore. Materiais e métodos utilizados para coleta de fluídos biológicos de 8 machos, 8 fêmeas da raça Holandês (Bos taurus taurus) e 8 machos, 8 fêmeas da raça Nelore ( Bos taurus indicus ). 


\subsection{Obtenção das amostras}

Todas as amostras utilizadas nos experimentos desse projeto foram coletadas de bovinos que apresentam fenótipos contrastantes à infestação do carrapato $R$. microplus, a saber: 8 bovinos machos (touros) resistentes pertencentes à raça Bos taurus indicus (Nelore) e 8 bovinos machos (touros) suscetíveis pertencentes à raça Bos taurus taurus (Holandês Preto e Branco), 8 vacas em lactação pertencentes à Bos taurus indicus (Nelore) e 8 vacas em lactação suscetíveis pertencentes à raça Bos taurus taurus (Holandês Preto e Branco). As amostras coletadas foram: soro, saliva, secreção nasal, urina, suor e biópsia de pele.

\subsubsection{Obtenção das amostras de soro}

Soros dos bovinos foram obtidos a partir de sangue periférico de bovinos macho e fêmea resistente e suscetível. O sangue periférico foi coletado por punção da veia jugular empregando tubos vacutainer sem anticoagulante (BD). Os tubos contendo o sangue dos bovinos foram mantidos em repouso para retração do coágulo e em seguida os mesmos foram centrifugados a $3220 \mathrm{~g}$ por $15 \mathrm{~min}$ a $4^{\circ} \mathrm{C}$. Soros obtidos foram armazenados em freezer a $-20^{\circ} \mathrm{C}$ até a utilização.

\subsubsection{Obtenção de amostras de saliva}

Saliva de bovinos resistentes e suscetíveis macho e fêmea foi coletada de acordo com protocolo descrito por Japaridze e colaboradores 2012 com algumas alterações (JAPARIDZE et al., 2012). Resumidamente, saliva dos bovinos foi coletada manualmente com auxílio de uma gaze auto clavada umedecida com tampão fosfato salina (PBS). A gaze umedecida foi passada no interior da boca de cada bovino com auxilio de uma pinça, retirando assim a saliva presente, e armazenada em tubos Nalgene. Após as amostras foram centrifugadas a $41000 \mathrm{xg}$ por 30 minutos, a $4^{\circ} \mathrm{C}$. Foram armazenados a $-20{ }^{\circ} \mathrm{C}$ até a utilização das mesmas. 


\subsubsection{Obtenção das amostras de secreção nasal}

Secreção nasal de bovinos resistentes e suscetíveis macho e fêmea foi coletada de acordo com protocolo descrito por Japaridze e colaboradores 2012 com algumas alterações (JAPARIDZE et al., 2012). A secreção nasal dos bovinos foi coletada manualmente com auxílio de uma gaze auto clavada umedecida com PBS. Está gaze umedecida foi passada no interior da foca nasal de cada bovino com auxilio de uma pinça, retirando assim toda a secreção nasal presente nas focas nasais, após foram armazenada em tubos Nalgene mantidos em gelo, e levadas ao laboratório, às amostras coletadas foram centrifugadas a $41000 \mathrm{xg}$ por 30 minutos, a $4^{\circ} \mathrm{C}$. Posteriormente foram armazenados a $-20{ }^{\circ} \mathrm{C}$ até a utilização das mesmas.

\subsubsection{Obtenção das amostras de Urina}

Amostras de urina foram obtidas dos bovinos no momento em que o animal urinava, todas as amostras foram coletadas em potes estéreis próprios para de urina. As amostras foram mantidas em gelo durante o transporte e em seguida estocadas a $-20{ }^{\circ} \mathrm{C}$ até a utilização das mesmas.

\subsubsection{Obtenção das amostras de suor}

Foram coletadas amostras de suor bovino através de câmara, onde foram adicionados $5 \mathrm{ml}$ de PBS, utilizando uma luz infravermelha sobre a câmara por 10 minutos a qual auxilia no processo de eliminação do suor, como demostrado na figura 02. Após 10 minutos o liquido presente dentro da câmara foi coletado com a pipeta paster descartável e armazenado em tubo nalgene. Armazenados a $-20{ }^{\circ} \mathrm{C}$ até a utilização das mesmas.

\subsubsection{Obtenção das amostras de biópsia de Pele}

Amostras de biópsia foram coletas dos bovinos utilizando punch de $6 \mathrm{~mm}$ (tamanho mínimo) individual novo e descartável, portanto ultra afiado, os animais não foram anestesiados porque afeta canais de cálcio e, portanto, a expressão de genes. 
Todas as biópsias de pele coletadas foram lavadas com PBS diluído 1/1000 e secadas em papel de filtro, após as biópsias foram preservadas em meio de criopreservação (Tissue-Tek $\left(\right.$ O.C.T, Sakura Finetek), mantidas a $-80^{\circ} \mathrm{C}$ até o uso.

\subsection{Quantificação das proteínas totais em todos os fluídos corpóreos coletados.}

Para realização da dosagem proteica (proteínas totais) das amostras saliva, suor, secreção nasal, urina e soro coletadas de bovinos machos e fêmea das raças resistente e suscetíveis, foi feito a quantificação por meio da técnica de Bradford (Coomassie Plus $^{\mathrm{TM}}$, Thermo Scientific, Rockford, IL- USA) conforme instruções do fabricante.

\subsection{Gel de poliacrilamida (SDS-Page)}

A fim de evidenciar a possível presença da Lipocalina Bovina nas amostras de soro, saliva, secreção nasal, urina e suor obtidas como descritas anteriormente, foram feitos géis de poliacrilamida (SDS-PAGE), técnica a qual separa as proteínas pelo seu peso molecular, e posteriormente para confirmar a presença da Lipocalina Bovina foi realizado Western Blot.

\subsubsection{Gel poliacrilamida 1D}

As amostras coletadas anteriormente dos bovinos macho e fêmea das raças resistente e susceptível foram separadas em gel de poliacrilamida como descrito a seguir: os soros foram separados por SDS- Page a 12,5\% e aplicados em cada canaleta 10ug de proteína total, saliva e secreção nasal foram separadas por SDS- Page a $15 \%$ cada canaleta contendo 30ug de proteína total, amostras de suor e urina também foram separadas por SDS-Page a 15\% porém em cada canaleta foi aplicado 15ug de proteína total em todos os géis foram usado peso molecular (Precision Plus Protein ${ }^{\mathrm{TM}}$ Standards, Bio Rad, catalog \#161-0373). Para aplicação das amostras em cada canaleta as amostras foram misturadas e fervidas com tampão da amostra (Tris/HCl pH 6,8 100mM SDS $4,0 \%$ Azul de bromofenol $0,2 \%$ Glicerol $20,0 \%$ ) por cinco minutos a $100^{\circ} \mathrm{C}$, deixando correr por 2 horas a $100 \mathrm{~V}$, após os géis foram corados com Coomassie Blue por 30 
minutos a temperatura ambiente e seguido de tratamento com o descorante.

\subsection{Western blot}

Amostras descritas no item 5.2, juntamente com a Lipocalina bovina recombinante (Recombinante bovine colostral odorant-binding protein - rbcOBP, cedida pelo Dr. Kenji Fukuda) utilizada como controle positivo (2mg). Para todos os fluídos coletados foi feito gel SDS-Page a 15\%, os fluídos soro, saliva e secreção nasal em cada canaleta do gel foi aplicado 30ug de proteína total, e para as amostras de suor e urina foi aplicado 15 ug de proteínas totais. Foi feito uma curva de 200ng, 100ng, 50ng, 25ng, Ong de rbcOBP, utilizada para analise semi-quantitativa da Lipocalina Bovina.

Os géis obtidos foram transferidos para membrana de nitrocelulose Hybond (Ge Healthcare) por 45 minutos, a $25 \mathrm{~V}$, a $300 \mathrm{~mA}$, usando cuba de transferência semi-seca

(Ge Healthcare). As membranas foram bloqueadas com soro albumina bovina (BSA) a $2 \%$ por uma hora, após as membranas foram lavadas com solução salina tamponada com tris (TBS) por 3 vezes, em seguida foram incubadas com anticorpo primário monoclonal lipocalin anti mouse $\operatorname{IgM}$ (1:1000, cedido pelo Dr. Kenji Fukuda) over night a $4^{\circ} \mathrm{C}$.

Posteriormente as membranas foram lavadas $3 \mathrm{x}$ por $5 \mathrm{~min}$, em seguida as membrans receberam anticorpo secundário anti mouse $\operatorname{IgM}(1: 1000$, Thermo Scientific, prod \#31440) conjugados com HRP, após as membranas foram lavadas 3x por $5 \mathrm{~min}$. A presença da proteína foi evidenciada com adição do substrato ECL Western Blotting Substrate (Thermo Scientific Pierce) pelo método de quimiluminescência usando sistema de detecção ImageQuant 350 detection system (Ge Healthcare). As amostras coletadas foram quantificadas pelo software image $\mathrm{J}$.

\subsection{Imuno-histoquímica}

As amostras de biópsia de pele foram cortada no criostato com espessura de $5 \mathrm{~mm}$, após as amostras ficaram descansando em temperatura ambiente por 30 minutos, em seguida foram embebecidas em acetona gelada (Sigma) por 10 minutos, após foram lavadas $3 \mathrm{X}$ em solução de lavagem contendo PBS1X $0,1 \%$ Tween $0,4 \%$ BSA aspirado a cada lavagem. Em seguida foi adicionado o Bloqueio da peroxidase endógena (solução 
Bloxall, Vector Laboratories) incubado a temperatura ambiente por 10min, em seguida foi feito a lavagem, após foi adicionado o Bloqueio Avidina (50ul de avidina block-Kit, Vector Laboratories) incubado a temperatura ambiente por 10min, em seguida as lâminas foram lavadas, adicionado o bloqueio Biotina (50ul de avidina block- Kit, Vector Laboratories) incubado a temperatura ambiente por $10 \mathrm{~min}$, em seguida foi feito bloqueio com BSA 2\% incubado a temperatura ambiente por $30 \mathrm{~min}$, após foi feito a lavagem, em seguida adiciona-se o anticorpo primário monoclonal lipocalin anti mouse $\operatorname{IgM}(1: 50)$ deixando incubado over night a $4^{\circ} \mathrm{C}$. Em seguida foi realizada a lavagem e incubada com anticorpo secundário anti mouse $\operatorname{IgM} \operatorname{HRP}(1: 50$, Thermo Scientific, prod \#31440). As lâminas foram lavadas em seguida incubadas com o Kit ABC (Vector Laboratories) conforme instruções do fabricante por $30 \mathrm{~min}$ em temperatura ambiente, após foi feito a lavagem das lâminas. Em seguida foi adicionado DAB (Vector Laboratories) no escuro conforme instruções do fabricante, após as amostras foram contra corada com hematoxilina. Para controle negativo foi utilizado amostra de biópsia de pele contendo apenas o anticorpo secundário.

\subsection{Escolha de peptídeo para produção de anticorpo policlonal em galinha (IgY).}

Para produção do anticorpo policlonal em galinha, foi feito uma busca na base de dado do site Uni prot (http://www.uniprot.org) de todas as proteínas que são encontradas e descritas em bovinos pertencentes à família da Lipocalina. As proteínas escolhidas para o alinhamento foram Q0IIA2 , G3X701, G3X701, G3X700, G3X799, E1BIJ6, G5E5W2, P07435, E1BJP1, E188Q2 e G3MZU3. A partir desta busca fez-se o alinhamento destas proteínas, e em seguida escolhemos o peptídeo (QETPAEIDPSKVVGEWRTIYAAADNKEKIVEGGPLRCYNR) que apresenta maior similaridade entre as proteínas da família da Lipocalina, posteriormente o peptídeo foi sintetizado pela empresa Biomatik (http://www.biomatik.com), apresentando 95\% de pureza, posteriormente foi utilizado para imunização.

\subsection{Produção de anticorpo policlonal em galinha}

Foram utilizadas duas galinhas, as quais foram imunizadas com o peptídeo 
oriundo do alinhamento das proteínas da família da Lipocalina presente em bovinos. As galinhas receberam 3 doses de imunizações com intervalos de 15 dias, a primeira imunização contendo $200 \mathrm{ug}$ peptídeo juntamente com o adjuvante completo de freund sendo a dose intramuscular, segunda imunização com 100ug de peptídeo mais adjuvante incompleto de Freund via subcutânea, e já a terceira imunização intramuscular com 50ug de peptídeo mais adjuvante completo de Freund. As galinhas foram alojadas em gaiolas dentro de espaço com ventilação e iluminação naturais. Os animais estavam saudáveis e com cerca de 110 dias e 1,3 kg. Cada animal recebeu diariamente água filtrada à vontade e ração específica para galinhas à vontade contendo proteína bruta, serviço fornecido pela empresa AGRARIAS - SERVICE.

\subsubsection{Purificação do anticorpo policlonal anti- Lipocalina Bovina (IgY anti - Lipocalina).}

Para purificação de $\operatorname{IgY}$ anti Lipocalina foram utilizados ovos coletados após a terceira imunização, primeiramente fez-se o processo de delipidação que consiste em um volume da gema para um volume de água mili Q apresentando pH entre 5.0 a 5.5, em seguida adicionou-se o volume da água sobre a gema incubando por seis horas sobre agitação lenta a $4^{\circ} \mathrm{C}$, posteriormente fez-se uma centrifugação a $10000 \mathrm{~g}$ por $25 \mathrm{~min}$ a $4^{\circ} \mathrm{C}$, separando então a fase liquida (onde contém as proteínas) da camada lipídica (precipitado em amarelo).

Posteriormente utiliza-se a fase líquida (medimos o volume), este volume foi precipitado com sulfato de amônio saturado a 45\% (pH 7.8), deixando over night sobre agitação lenta a $4^{\circ} \mathrm{C}$. No dia seguinte centrifuga-se o líquido deixado precipitando a 10000rpm por 10 minutos, em seguida fazem-se mais duas precipitações (a cada precipitação o pellet foi ressuspendido em PBS, deixando sempre no mesmo volume inicial). Após as repetidas precipitações, o precipitado foi ressuspendido em um volume de menor $(50 \mathrm{ml})$.

O próximo passo foi concentrar volume de $50 \mathrm{ml}$ para $10 \mathrm{ml}$, e em seguida foi realizado o processo de diálise através do sistema Amicon, utilizando uma membrana de YM100 (já que o peso molecular da IgY 160.00 a 180.00) e PBS (adicionou-se no Amicon o máximo de volume possível), o processo de diálise terminou quando a amostras não apresentava mais sulfato de amônio saturado, teste feito com Cloreto de 
Bário (1\%). Após foi feito uma concentração deste volume deixando de $5 \mathrm{ml}$.

\subsubsection{Dosagem proteica do anticorpo policlonal anti- Lipocalina Bovina (IgY anti - Lipocalina) pelo método de Bradford.}

Para realização da dosagem proteica (proteínas totais) do anticorpo produzido em galinha anti- Lipocalina bovina, foi feito a quantificação por meio da técnica de Bradford (Coomassie Plus ${ }^{\mathrm{TM}}$, Thermo Scientific, Rockford, IL- USA) conforme instruções do fabricante.

\subsubsection{Avaliação da pureza do anticorpo policlonal anti- lipocalina Bovina (IgY anti - lipocalina)}

A avalição foi feita através do gel de poliacrilamida na presença de Dodecil Sulfato de Sodio (SDS- Page). A amostra de anticorpo ( $\operatorname{IgY}$ ) foi misturada e fervida com tampão da amostra (Tris/HCl pH 6,8 100mM SDS 4,0\% Azul de bromofenol 0,2\% Glicerol $20,0 \%$ ) por cinco minutos a $100^{\circ} \mathrm{C}$, deixando correr por 2 horas a $100 \mathrm{~V}$, após os géis foram corados com Coomassie Blue por 30 minutos a temperatura ambiente e seguido de tratamento com o descorante.

\subsubsection{Avaliação da atividade do anticorpo policlonal anti- Lipocalina Bovina (IgY anti - Lipocalin)}

A atividade do anticorpo foi avaliada por meio da técnica de Western Blot, onde foi avaliada sua atividade reconhecendo o peptídeo imunizado, recombinante e amostras coletadas.

O peptídeo (30ug), recombinante rbcOBP (4mg), saliva (30ug) e secreção nasal (30ug) foram misturada e fervida com tampão da amostra (Tris/ $\mathrm{HCl} \mathrm{pH} \mathrm{6,8} \mathrm{100mM}$ SDS 4,0\% Azul de bromofenol 0,2\% Glicerol 20,0\%) por cinco minutos a $100^{\circ} \mathrm{C}$, deixando correr por 2 horas a 100V. Os géis obtidos foram transferidos para membrana de nitrocelulose Hybond (Ge Healthcare) por 45 minutos, a $25 \mathrm{~V}$, a 300mA, usando cuba de transferência semi-seca (Ge Healthcare). As membranas foram bloqueadas com soro albumina bovina (BSA) a $2 \%$ por uma hora, após as membranas foram lavadas com solução salina tamponada com tris (TBS) por 3 vezes, em seguida foram incubadas 
com anticorpo primario policlonal IgY anti- Lipocalina Bovina (1:1000) over night a $4^{\circ} \mathrm{C}$. Posteriormente as membranas foram lavadas $3 \mathrm{x}$ por $5 \mathrm{~min}$, em seguida as membranas receberam anticorpo secundário anti mouse IgY (1:1000, Bethyl A30-106P) conjugados com HRP, após as membranas foram lavadas 3x por $5 \mathrm{~min}$. A presença da proteína foi evidenciada com adição do substrato ECL Western Blotting Substrate (Thermo Scientific Pierce) pelo método de quimiluminescência usando sistema de detecção ImageQuant 350 detection system (Ge Healthcare).

\subsection{ELISA}

\subsubsection{ELISA usando IgM anti lipocalin como anticorpo primário, IgY como anticorpo secundário e Anti-IgY}

Foram feitos vários testes em resumo foi utilizado placas de 96 poços (Costar ), foi feito o coating da placa como anticorpo de captura IgM anti lipocalin em diferentes concentrações ( Ex: 1:100; 1:500; 1:1000, entre outras ) deixando overninght a $4^{\circ} \mathrm{C}$. No dia seguinte as placas foram lavadas 5 vezes com 300 ul por poço de PBS-T 0,05\%, em seguida adicionou-se, a curva com a recombinante da lipocalina bovina (rbcOBP), a curva apresentava as sequintes concentração 400ng, 200ng, 100ng, 50ng, 25 ng, 12,5ng, deixando em temperatura ambiente por duas horas, em seguinda foi utilizado dieferentes bloqueios como soro de cabra (5\%), albumina do soro bovino (BSA 2\%, 5\%, e 10\%), gelatina $(3 \%, 5 \%)$, bloqueio comercial $(5 \%, 2 \%)$, todos ficaram em temperatura ambiente por 1 hora, as placas foram lavadas 5 vezes com 300ul por poço de PBS-T 0,05\%, posteriormente incubadas com anticorpo de detecção IgY anti lipocalin em diferentes concentrações (Ex: 1:100; 1:500; 1:1000; 1:2000 entre outras) por duas horas a temperatura ambiente, em seguida placas foram lavadas 5 vezes com 300ul de PBS-T $0,05 \%$, depois as placas foram incubadas com anticorpo secundário anti-IgY (Bethyl) em diferentes concentrações $(1: 500 ; 1: 1000 ; 1: 2000$ entre outras logo depois as placas foram lavadas 5 vezes com 300ul de PBS-T 0,05\%, a seguir as placas foram incubadas no escuro com TMB (Sigma) por 30 minutos. 


\subsubsection{ELISA usando IgY anti lipocalin como anticorpo primário, IgM como anticorpo secundário e Anti-IgM.}

Foram feitos vários testes em resumo foi utilizado placas de 96 poços (Costar), foi feito o coating da placa como anticorpo de captura $\operatorname{IgY}$ anti lipocalin em diferentes concentrações ( Ex: 1:100; 1:500; 1:1000, entre outras ) deixando overninght a $4^{\circ} \mathrm{C}$. No dia seguinte as placas foram lavadas 5 vezes com $300 \mathrm{ul}$ por poço de PBS-T 0,05\%, em seguida adicionou-se, a curva com a recombinante da lipocalina bovina (rbcOBP), a curva apresentava as seguintes concentração 400ng, 200ng, 100ng, 50ng, 25 ng, 12,5ng, deixando em temperatura ambiente por duas horas, em seguida foi utilizado diferentes bloqueios como soro de cabra (5\%), albumina do soro bovino (BSA 2\%, 5\%, e 10\%), gelatina $(3 \%, 5 \%)$, bloqueio comercial $(5 \%, 2 \%)$, todos ficaram em temperatura ambiente por 1 hora, as placas foram lavadas 5 vezes com 300ul por poço de PBS-T 0,05\%, posteriormente incubadas com anticorpo de detecção $\operatorname{IgM}$ anti lipocalin em diferentes concentrações (Ex: 1:100; 1:500;1:1000; 1:2000 entre outras) por duas horas a temperatura ambiente, em seguida placas foram lavadas 5 vezes com 300ul de PBS-T $0,05 \%$, depois as placas foram incubadas com anticorpo secundário anti-IgM (Thermo Scientific) em diferentes concentrações (1:500; 1:1000; 1:2000 entre outras logo depois as placas foram lavadas 5 vezes com 300ul de PBS-T 0,05\%, a seguir as placas foram incubadas no escuro com TMB (Sigma) por 30 minutos.

\subsection{Análise estatística}

Os resultados estão representados como média \pm desvio padrão (DP). As diferenças estatísticas foram determinadas utilizando-se o teste t de Student. A análise de variância (ANOVA) seguida pelo pós-teste de Tukey foi aplicado para amostras com distribuições normais. As análises foram realizadas através do programa Sigma Plot e foram consideradas estatisticamente significativas quando os valores de $\mathrm{P}$ eram iguais ou menores a 0,05 . 


\section{RESULTADOS}

\subsection{Presença da Lipocalina bovina nos diferentes fluídos.}

Verifiquei primeiramente se a bcOBP estaria presente em soro, saliva, suor, secreção nasal e urina de touros e vacas em lactação das raças resistentes (Bos taurus indicus - Nelore) e suscetíveis (Bos taurus taurus - Holandês Preto e Branco, HPB) a infestações com o $R$. microplus. Para isso separamos as proteínas contidas nesses fluidos por meio de SDS-PAGE, coramos os géis obtidos com azul de Coomassie e verificamos se havia presença de banda proteica correspondente ao peso molecular da bcOBP, de aproximadamente de $20 \mathrm{kDa}$.

Os resultados relativos a amostras de soros bovinos separados por SDS-PAGE podem ser vistos na Figura 3, mostram que todas continham uma banda aproximadamente $20 \mathrm{kDa}$, correspondente ao peso molecular da bcOBP (demarcado nas Figuras 3A-D por retângulos vermelhos), não havendo diferença de acordo com sexo ou raça do animal quanto à presença da banda. 

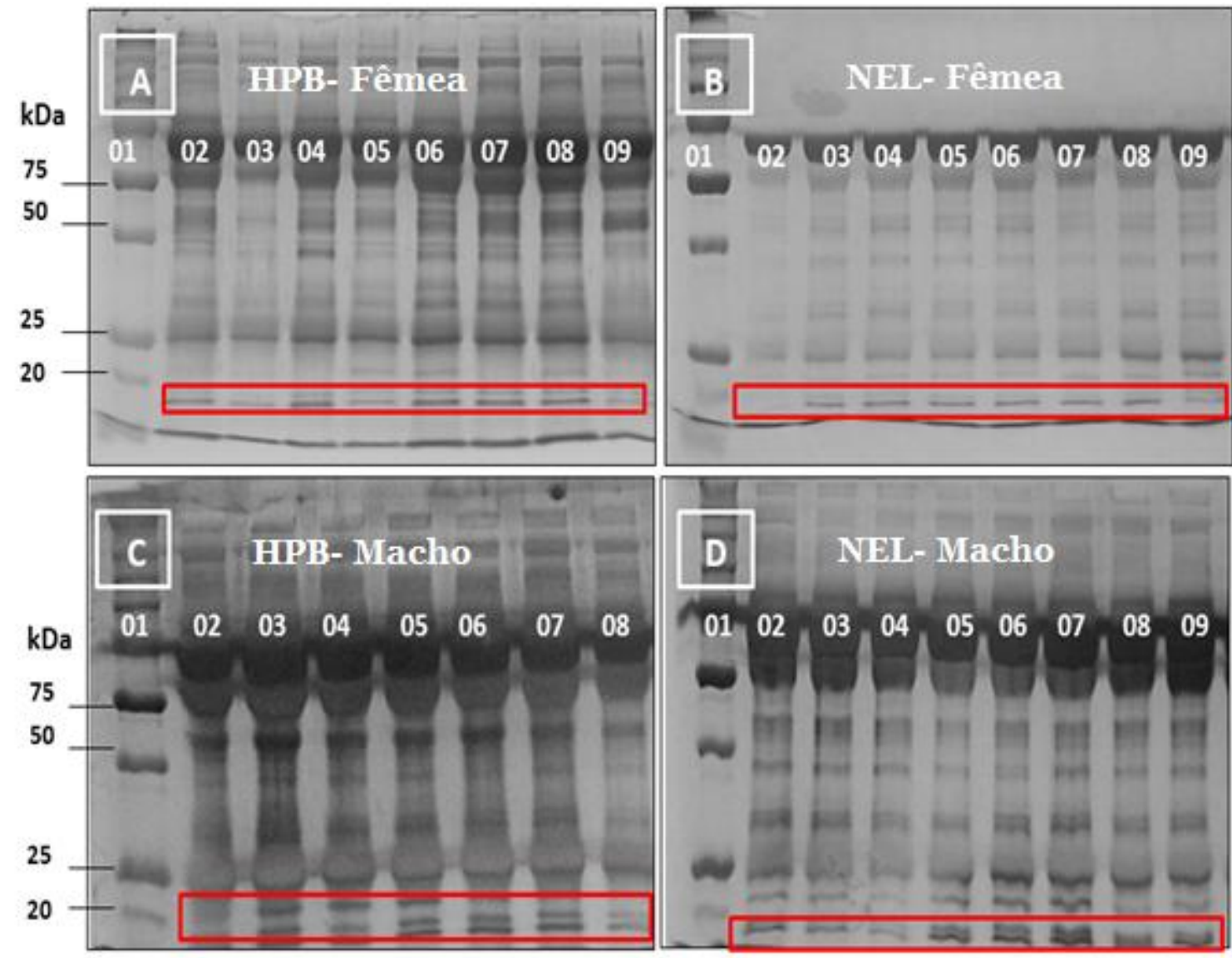

Figura 03: Perfil proteico das amostras de soro total de touros e vacas em lactação das raças HPB e Nelore (SDS-PAGE 12,5\%). Os géis foram corados por azul de Coomassie. O retângulo em vermelho demarca a banda cujo peso molecular corresponde ao da bcOBP. A) Soro total de vacas em lactação da raça HPB; canaleta 01: MPM, 6ul; canaletas de 02-09: 10ug de proteínas de soro total dos animais de números 24, 38, 64, 67, 75, 98, 100 e 107, respectivamente. B) Soro total de vacas em lactação da raça Nelore (NEL); canaleta 01: MPMs, 6ul; canaletas de 02-09: 10ug de proteínas de soro total dos animais de números 813, 1441, 1813, 1937, 1973, 3030, 3443 e 3983, respectivamente. C) Soro total de touros da raça HPB; canaleta 01: MPMs, 6ul; canaletas de 02-09: 10ug de proteínas de soro total dos animais de números1518, 1522, 1523, 1532, 1536,1537,1539, respectivamente. D) Soro total de touros da raça Nelore (NEL); canaleta 01: MPMs, 6ul; canaletas de 02-09: 10ug de proteínas de soro total dos animais de números 440, 442, 443, 444, 447, 456, 468 e 470, respectivamente.

Em seguida, verifiquei se bcOBP está presente em amostras de saliva de bovinos de ambos os sexos e raças. De acordo com as imagens das proteínas salivares bovinas separadas por meio de SDS-PAGE, apresentadas na Figura 4, pude concluir que a bcOBP possivelmente está presente em salivas de ambos os sexos e raças devido à presença da banda de aproximadamente $20 \mathrm{kDa}$ correspondente ao peso molecular da bcOBP (demarcadas nos retângulos em vermelhos). Além disso, os resultados sugerem que fêmeas em lactação de bovinos Nelore possuem níveis menores de bcOBP que os demais grupos de bovinos estudados. 


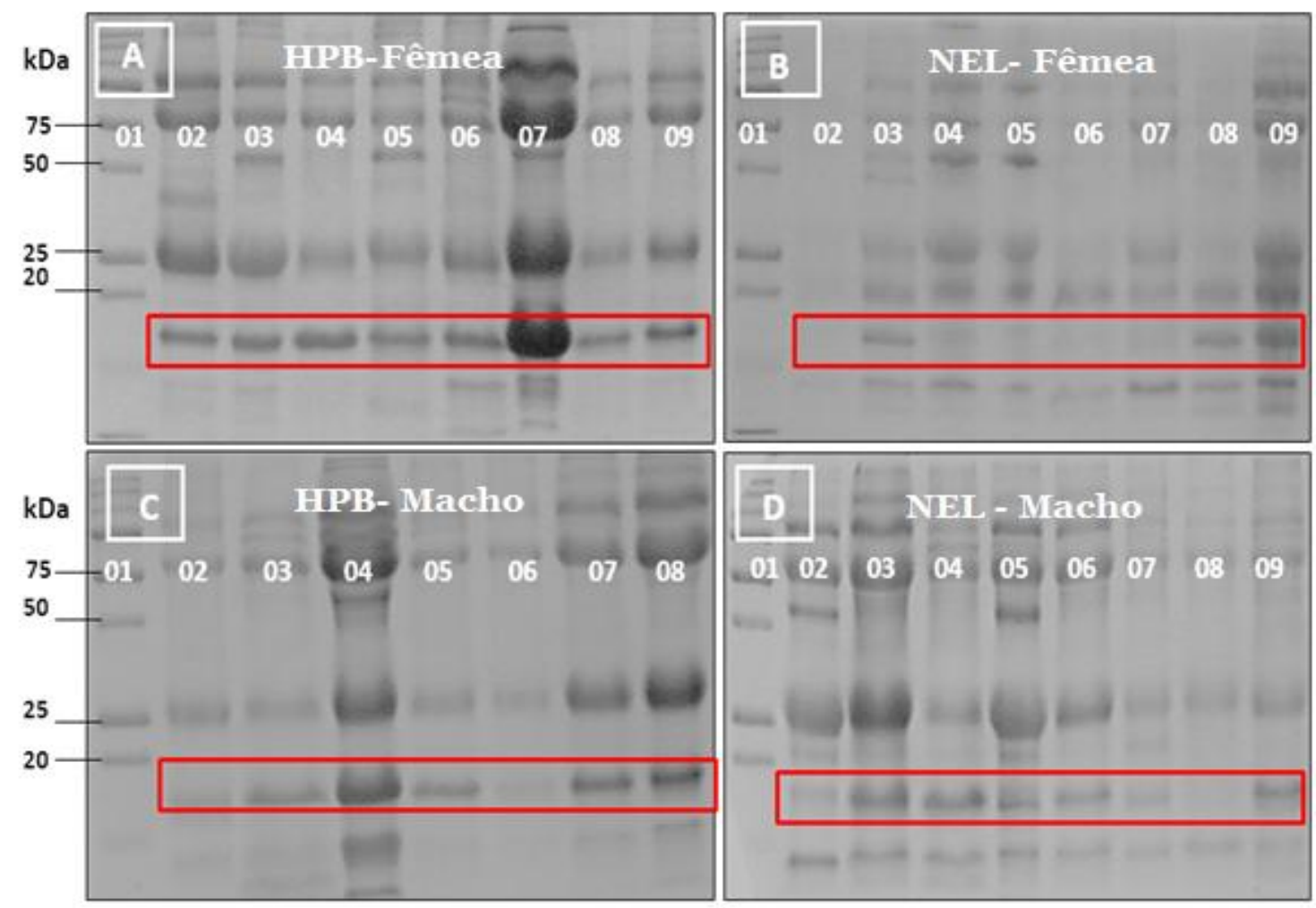

Figura 04: Perfil proteico das amostras de saliva de vacas em lactação e touros das raças HPB e Nelore (SDS-PAGE 15\%). Os géis foram corados por azul de Coomassie. O retângulo em vermelho demarca a banda cujo peso molecular corresponde ao da bcOBP. A) Saliva de vacas em lactação da raça HPB; canaleta 01: MPM, 6ul; canaletas de 02-09: 30ug de proteínas de saliva dos animais de números $24,38,64,67,75,98,100$ e 107, respectivamente. B) Saliva de vacas em lactação da raça Nelore (NEL); canaleta 01: MPMs, 6ul; canaletas de 02-09: 30ug de proteínas de saliva dos animais de números 813, 1441, 1813, 1937, 1973, 3030, 3443 e 3983, respectivamente. C) Saliva de touros da raça HPB; canaleta 01: MPMs, 6ul; canaletas de 02-09: 30ug de proteínas de saliva dos animais de números1518, 1522, 1523, 1532, 1536,1537,1539, respectivamente. D) Saliva de touros da raça Nelore (NEL); canaleta 01: MPMs, 6ul; canaletas de 02-09: 30ug de proteínas de saliva dos animais de números 440, 442, $443,444,447,456,468$ e 470, respectivamente.

Também verifiquei se bcOBP está presente em amostras de suor de bovinos de ambos os sexos e raças. De acordo com as imagens das proteínas salivares bovinas separadas por meio de SDS-PAGE, apresentadas na Figura 5, pude concluir que a bcOBP possivelmente está presente em suores de ambos os sexos e raças devido à presença da banda de aproximadamente $20 \mathrm{kDa}$ correspondente ao peso molecular da bcOBP (demarcadas nos retângulos em vermelhos). Além disso, como verificado em relação à saliva desses animais, os resultados também sugerem que fêmeas em lactação de bovinos Nelore possuem níveis menores de bcOBP que os demais grupos de bovinos estudados. 

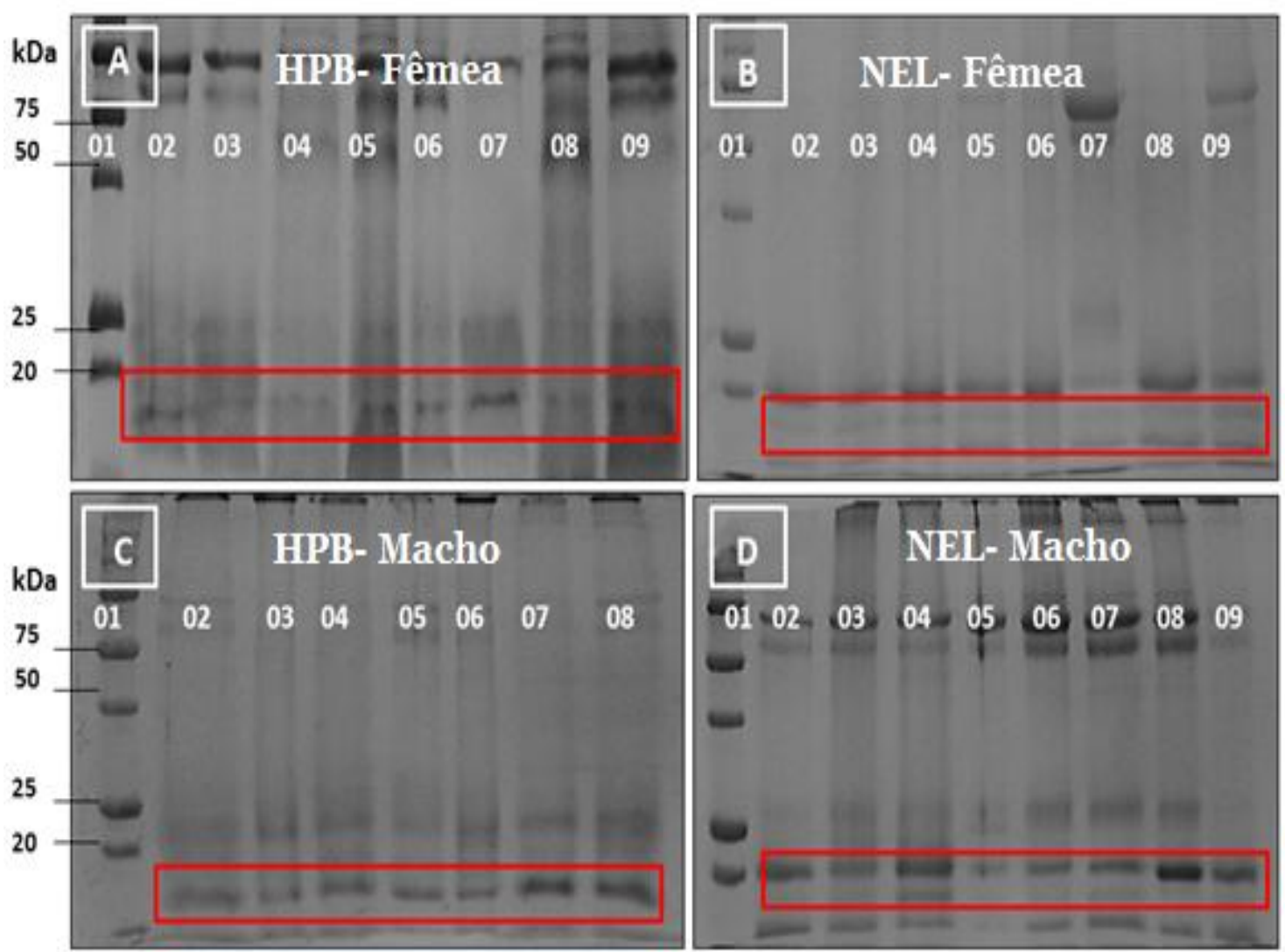

Figura 05: Perfil proteico das amostras de suor de vacas em lactação e touros das raças HPB e Nelore (SDS-PAGE 15\%). Os géis foram corados por azul de Coomassie. O retângulo em vermelho demarca a banda cujo peso molecular corresponde ao da bcOBP. A) Suor de vacas em lactação da raça HPB; canaleta 01: MPM, 6ul; canaletas de 02-09: 15ug de proteínas de suor dos animais de números 24, 38, 64, 67, 75, 98, 100 e 107, respectivamente. B) Saliva de vacas em lactação da raça Nelore (NEL); canaleta 01: MPMs, 6ul; canaletas de 0209: 30ug de proteínas de saliva dos animais de números 813, 1441, 1813, 1937, 1973, 3030, 3443 e 3983, respectivamente. C) Suor de touros da raça HPB; canaleta 01: MPMs, 6ul; canaletas de 02-09: 15ug de proteínas de saliva dos animais de números1518, 1522, 1523, 1532, 1536,1537,1539, respectivamente. D) Suor de touros da raça Nelore (NEL); canaleta 01: MPMs, 6ul; canaletas de 02-09: 15ug de proteínas de saliva dos animais de números 440, 442, 443, 444, 447, 456, 468 e 470, respectivamente.

A análise dos SDS-Page das amostras de secreção nasal dos grupos de bovinos estudados permitiu verificar que a bcOBP está também possivelmente presente nesse tipo de fluido (Figura 6). 

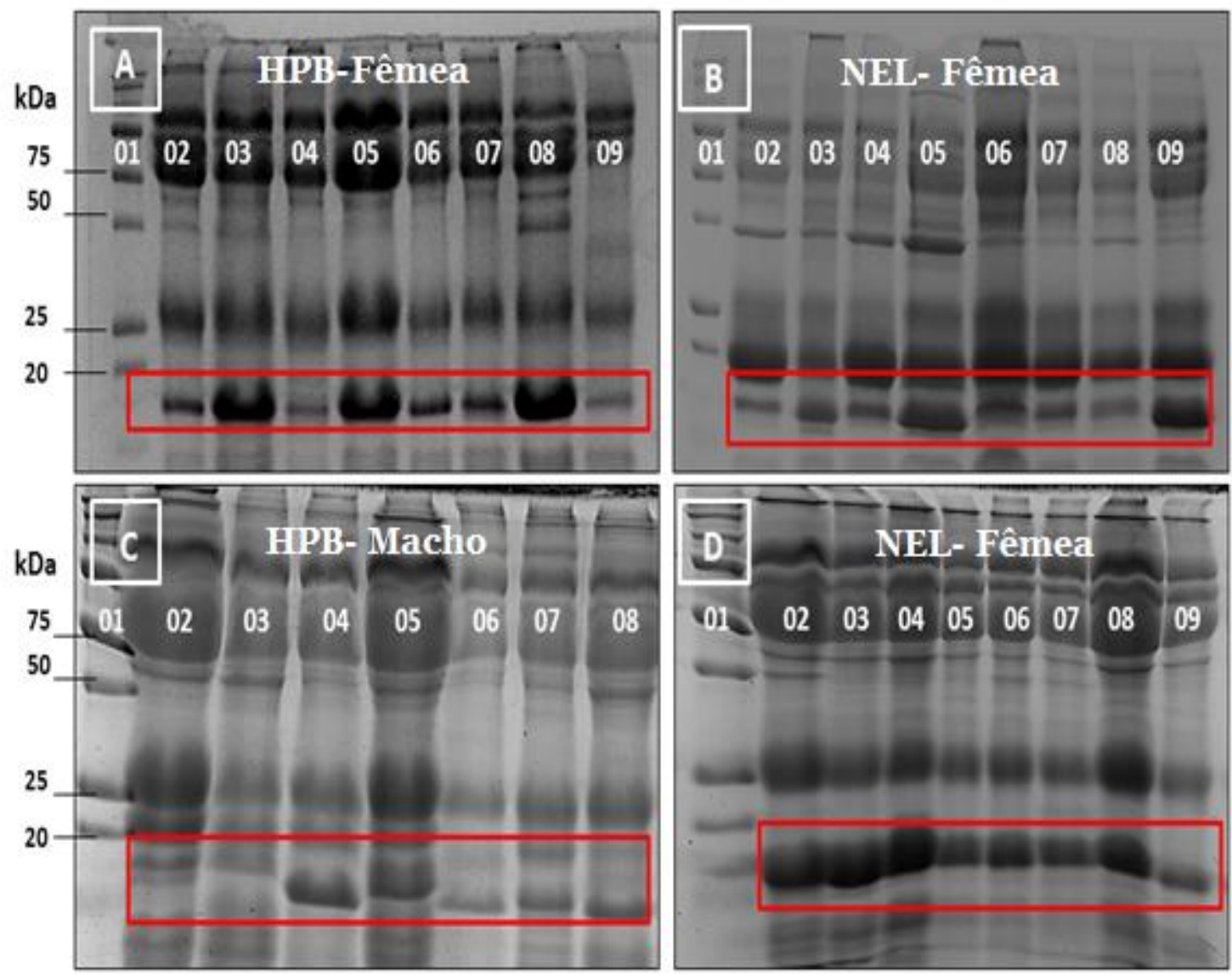

Figura 06: Perfil proteico das amostras de secreção nasal de vacas em lactação e touros das raças HPB e Nelore (SDS-PAGE 15\%). Os géis foram corados por azul de Coomassie. O retângulo em vermelho demarca a banda cujo peso molecular corresponde ao da bcOBP. A) Secreção nasal de vacas em lactação da raça HPB; canaleta 01: MPM, 6ul; canaletas de 0209: 30ug de proteínas de secreção nasal dos animais de números $24,38,64,67,75,98,100$ e 107, respectivamente. B) Secreção nasal de vacas em lactação da raça Nelore (NEL); canaleta 01: MPMs, 6ul; canaletas de 02-09: 30ug de proteínas de secreção nasal dos animais de números 813, 1441, 1813, 1937, 1973, 3030, 3443 e 3983, respectivamente. C) Secreção nasal de touros da raça HPB; canaleta 01: MPMs, 6ul; canaletas de 02-09: 30ug de proteínas de secreção nasal dos animais de números1518, 1522, 1523, 1532, 1536,1537,1539, respectivamente. D) Secreção nasal de touros da raça Nelore (NEL); canaleta 01: MPMs, 6ul; canaletas de 02-09: 30ug de proteínas de secreção nasal dos animais de números 440, 442, $443,444,447,456,468$ e 470 , respectivamente.

Por fim, analisei o perfil proteico das amostras de urina dos bovinos estudados. Os perfis estão apresentados na Figura 7 onde se pode verificar que a urina de todos os animais apresentam banda de aproximadamente $20 \mathrm{kDa}$ correspondente ao peso molecular da bcOBP (demarcadas nos retângulos em vermelhos). 

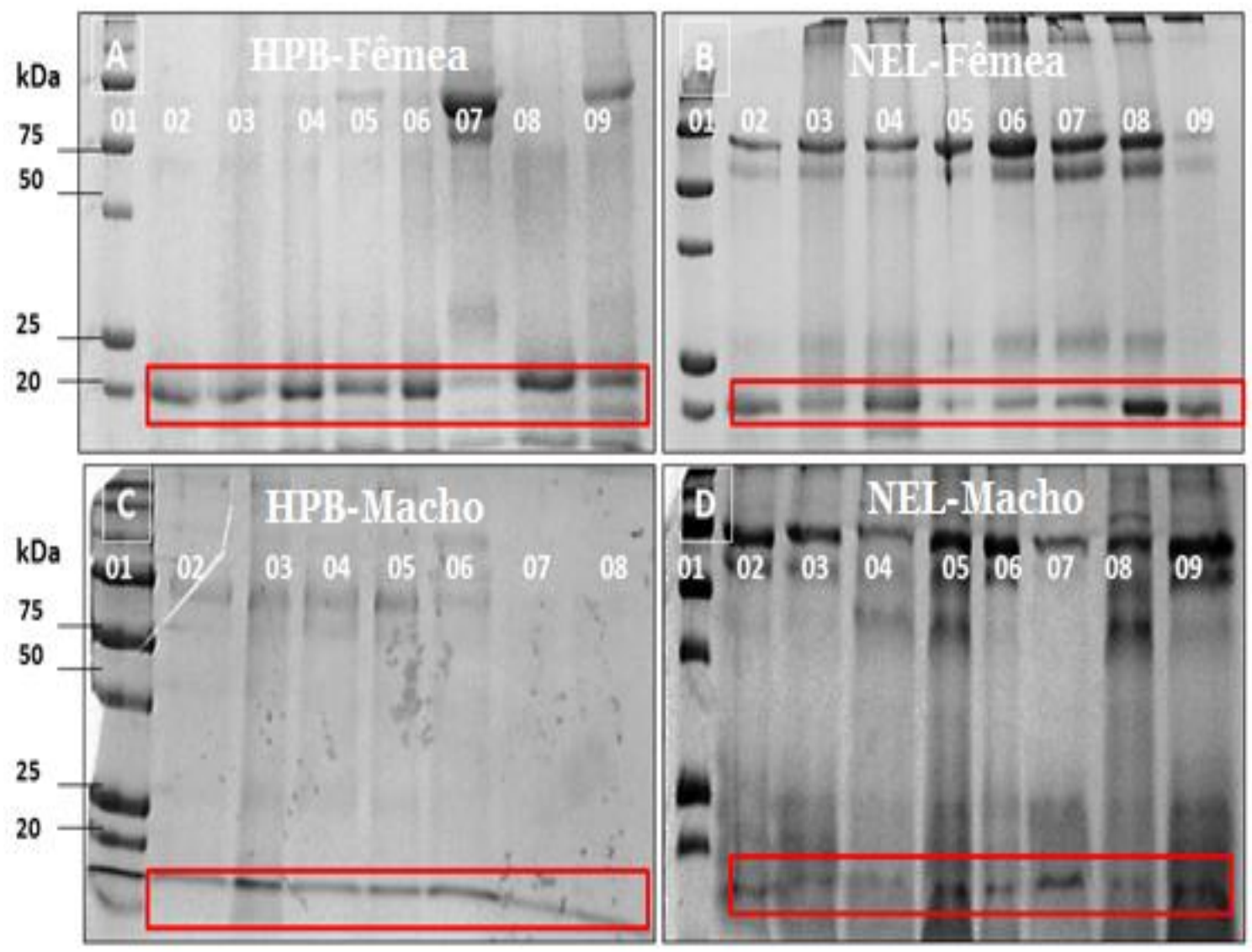

Figura 07: Perfil proteico das amostras de urina de vacas em lactação e touros das raças HPB e Nelore (SDS-PAGE 15\%). Os géis foram corados por azul de Coomassie. O retângulo em vermelho demarca a banda cujo peso molecular corresponde ao da bcOBP. A) Urina de vacas em lactação da raça HPB; canaleta 01: MPM, 6ul; canaletas de 02-09: 30ug de proteínas de secreção nasal dos animais de números $24,38,64,67,75,98,100$ e 107, respectivamente. B) Urina de vacas em lactação da raça Nelore (NEL); canaleta 01: MPMs, 6ul; canaletas de 02-09: 30ug de proteínas de secreção nasal dos animais de números 813, 1441 , 1813, 1937, 1973, 3030, 3443 e 3983, respectivamente. C) Urina de touros da raça HPB; canaleta 01: MPMs, 6ul; canaletas de 02-09: 30ug de proteínas de secreção nasal dos animais de números1518, 1522, 1523, 1532, 1536,1537,1539, respectivamente. D) Urina de touros da raça Nelore (NEL); canaleta 01: MPMs, 6ul; canaletas de 02-09: 30ug de proteínas de secreção nasal dos animais de números 440, 442, 443, 444, 447, 456, 468 e 470, respectivamente.

Em resumo, conforme visto nas figuras 03 a 07 todos os fluidos coletados de bovinos machos e fêmeas das raças Nelore e HPB (soro, saliva, suor, secreção nasal e urina) possivelmente apresentam a bcOBP, embora os perfis sugiram que existem diferenças nas quantidades dessa proteína conforme a raça ou sexo do animal. 


\subsection{Confirmação da presença e análise semi-quantitativa da bcOBP nos diferentes}

fluidos corpóreos de touros e vacas em lactação das raças HPB e Nelore.

Conforme observado nos géis de SDS-PAGE descritos anteriormente (item 4.1), todos os fluidos analisados (soro, saliva, suor, secreção nasal e urina) possivelmente apresentam a bcOBP porque contêm uma banda de aproximadamente $20 \mathrm{kDa}$ que corresponde ao peso molecuar da proteína de interesse. Portanto, com o intuito de confirmar se realmente a bcOBP está presente nos fluidos coletados e se poderia existir diferença nas quantidades presentes no animais das diferentes raças e diferentes sexos, foram feitas análises de Western Blot de amostras de soro, saliva, suor, secreção nasal, e urina, bem como a quantificação das bandas correspondentes à bcOBP. Essa quantificação foi realizada em função de uma curva estabelecida com a bcOBP recombinante por meio de densitometria como programa image J (Figura 8). Abaixo estão descritos os dados obtidos para cada fluido corpóreo.

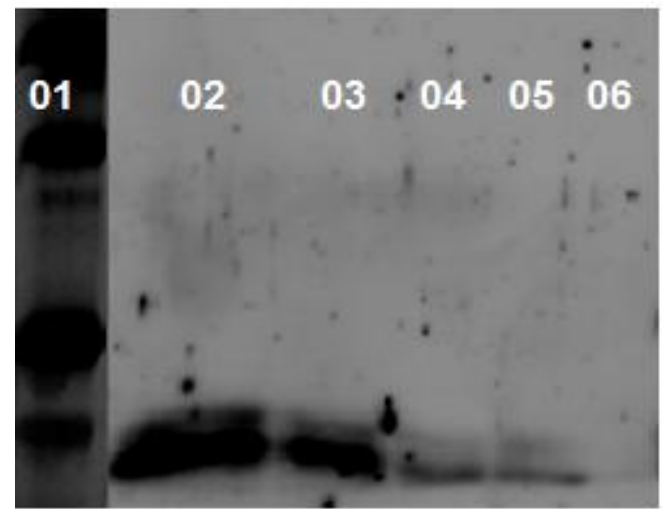

Figura 08: Curva padrão da recombinante de bcOBP (rbcOBP) usada para quantificação da bcOBP nos diferentes fluídos por meio de densitometria. Western blot da rbcOBP reagidas com anticorpo monoclonal específico para bcOBP; canaleta 01: MPM, 6ul; as canaletas de 02 a 06 contém diferentes concentrações de rbcOBP, 02: 200ug, 03: 100ug, 04: 50ug, 05: 25ug, 06: Oug. O anticorpo primário usado foi IgM de camundongo anti-bcOBP diluído a 1:1000 e secundário foi o anticorpo IgM anti-IgM de camundongo diluído a 1:1000, revelados com ECL conforme instruções do fabricante. A curva padrão foi preparada de acordo com o descrito na seção 3.5 e a intensidade das bandas foi aferida por meio do programa Image $\mathrm{J}$. 


\subsubsection{Presença e analise semi-quantitativa de Western Blot da bcOBP em amostras de soro total coletado de touros e vacas em lactação das raças Holandês e Nelore.}

Como podemos observar na Figura 9A, a reatividade de proteínas do soro das vacas em lactação das raças HPB e Nelore com o anticorpo monoclonal específico para a bcOBP confirma que esta proteína está presente em nesses fluidos. A quantificação das bandas da bcOBP por imagem $\mathbf{J}$ permitiu concluir que não existiam diferenças significativas entre as vacas dessas duas raças (Figura 9B).

A

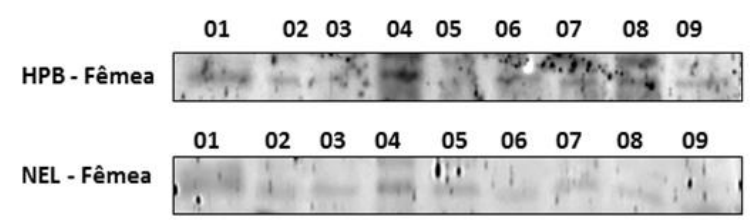

B
Quantificação da Lipocalina Bovina (bcOBP) em amostras de soro total de bovinos fêmea das raça Holandês (Bos taurus taurus) e Nelore (Bos taurus indicus)

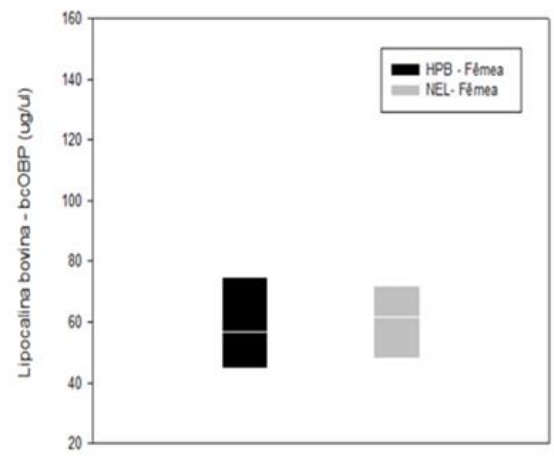

Figura 09: Detecção e quantificação de bcOBP por meio de Western Blot e de densitometria de Western blot de amostras de soro total de vacas em lactação das raças HPB e Nelore. A) Western blot de soros de vacas reagidas com anticorpo monoclonal específico para bcOBP; canaleta 01 dos blots superior e inferior: rbcOBP ( $2 \mathrm{mg})$; canaletas de 02 a 09 do blot superior: 30 ug de proteínas de soro total dos animais de números 24, 38, 64, 67, 75, 98, 100 e 107 (amostras de vacas HPB); canaletas de 02 a 09 do blot inferior: 30 ug de proteínas de soro total dos animais de números 813, 1441, 1813, 1937, 1973, 3030, 3443 e 3983 (amostras de vacas Nelore). B) Quantificação de bandas obtidas em Western blot das amostras de soro total das amsotras avaliadas na Figura 9A. O anticorpo primário usado foi IgM de camundongo anti-bcOBP diluído a 1:1000 e secundário foi o anticorpo IgM anti-IgM de camundongo diluído a 1:1000, revelados com ECL conforme instruções do fabricante. A curva padrão foi preparada de acordo com o descrito na seção 3.5 e a intensidade das bandas foi aferida por meio do programa Image $J$.

Considerando o resultado da Figura 10, podemos concluir que touros nelore e HPB apresentam bcOBP (figura 10.A), e que existe um aumento significativa para touro HPB ( $\mathrm{P}=0,014$, ver fig. 10. B). 
A

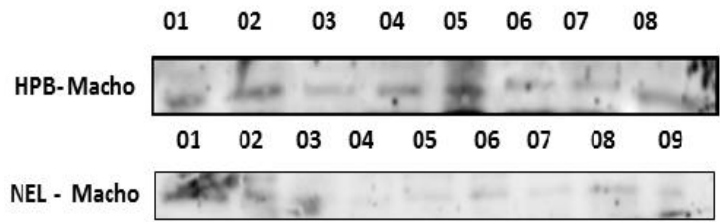

B

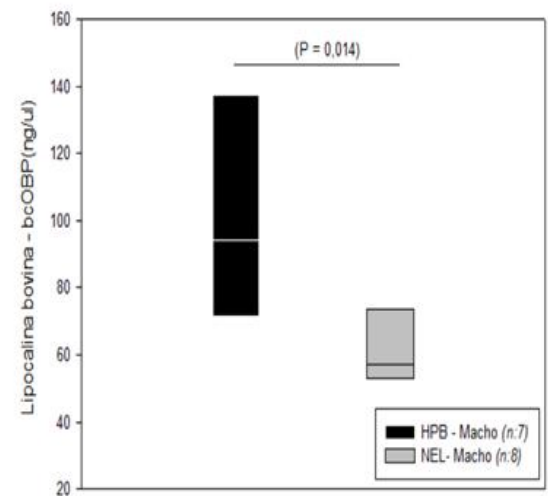

Figura 10: Detecção e quantificação de bcOBP por meio de Western Blot e de densitometria de Western blot de amostras soro total de touros raças HPB e Nelore. A) Western blot de soros de touros reagidas com anticorpo monoclonal específico para bcOBP; canaleta 01 dos blots superior e inferior: rbcOBP $(2 \mathrm{mg})$; canaletas de 02 a 09 do blot superior: 30 ug de proteínas de soro total dos animais de números 1518, 1522, 1523, 1532, 1536, 1537, 1539 (amostras de touros HPB); canaletas de 02 a 09 do blot inferior: 30 ug de proteínas de soro total dos animais de números 440, 442, 443, 444, 447, 456, 468, 470 (amostras de touros Nelore). B) Quantificação de bandas obtidas em Western blot das amostras de soro total das amostras avaliadas na Figura 10A. O anticorpo primário usado foi IgM de camundongo antibcOBP diluído a 1:1000 e secundário foi o anticorpo IgM anti-IgM de camundongo diluído a 1:1000, revelados com ECL conforme instruções do fabricante. A curva padrão foi preparada de acordo com o descrito na seção 3.5 e a intensidade das bandas foi aferida por meio do programa Image $\mathrm{J}(\mathrm{P}=0,014)$.

Ao analisar o Western blot de amostras de soro total na figura 10, o resultado nos permite concluir que touros e vacas em lactação HPB apresentam a banda da bcOBP (fig.11. A), e existe uma maior diferença significativa para touros HPB $(\mathrm{P}=0,040$, fig.11.B).

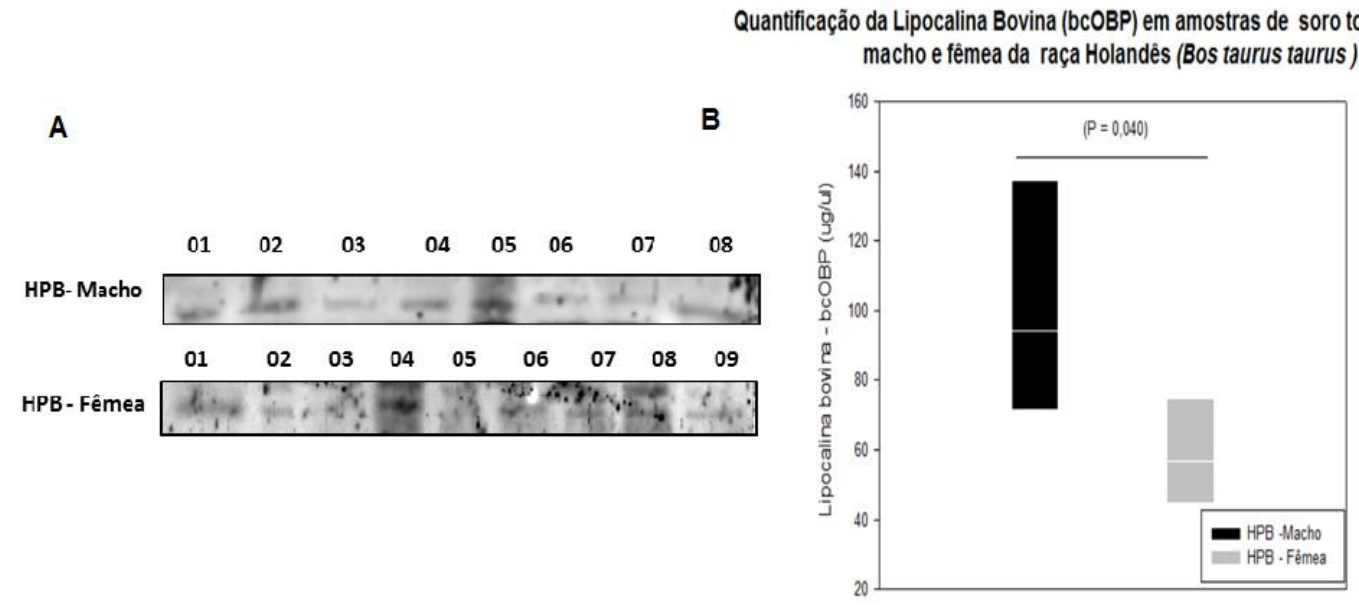

Figura 11: Detecção e quantificação de bcOBP por meio de Western Blot e de densitometria de Western blot de amostras soro total de touros e vacas da raça HPB. A) 
Western blot de soros de touros e vacas em lactação reagidas com anticorpo monoclonal específico para bcOBP; canaleta 01 dos blots superior e superior: rbcOBP $(2 \mathrm{mg})$; canaletas de 02 a 09 do blot superior: 30 ug de proteínas de soro total dos animais de números 1518, 1522, 1523, 1532, 1536, 1537, 1539 (amostras de touros HPB); canaletas de 02 a 09 do blot inferior: 30 ug de proteínas de soro total dos animais de números 24, 38, 64, 67, 75, 98, 100 e 107 (amostras de vacas HPB); B) Quantificação de bandas obtidas em Western blot das amostras de soro total das amostras avaliadas na Figura 11A. O anticorpo primário usado foi IgM de camundongo anti-bcOBP diluído a 1:1000 e secundário foi o anticorpo IgM anti-IgM de camundongo diluído a 1:1000, revelados com ECL conforme instruções do fabricante. A curva padrão foi preparada de acordo com o descrito na seção 3.5 e a intensidade das bandas foi aferida por meio do programa Image $\mathrm{J}(\mathrm{P}=0,014)$.

De acordo com a análise de Western Blot na Figura 12, concluímos que touros e vacas em lactação Nelore apresentam bcOBP no soro ( fig. 12. A), e que não apresentam diferença significativa entre os sexos (fig. 12. B).

Quantificação da Lipocalina Bovina (bcOBP) em amostras de soro total de bovinos macho e fêmea das raça Nelore (Bos taurus indicus)

A

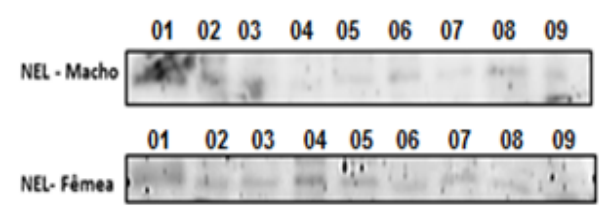

B

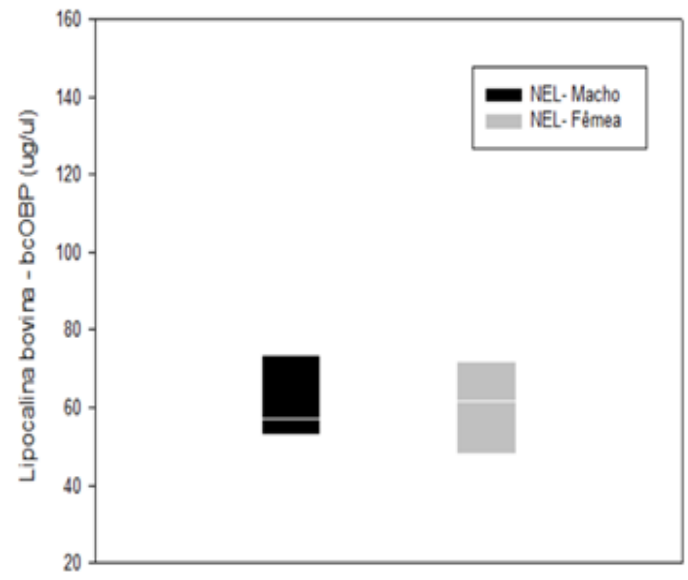

Figura 12: Detecção e quantificação de bcOBP por meio de Western Blot e de densitometria de Western blot de amostras soro total de touros e vacas em lactação da raça Nelore. A) Western blot de soros de touros e vacas em lactação reagidas com anticorpo monoclonal específico para bcOBP; canaleta 01 dos blots superior e inferior: rbcOBP $(2 \mathrm{mg})$; canaletas de 02 a 09 do blot superior: 30 ug de proteínas de soro total dos animais de números 440, 442, 443, 444, 447, 456, 468, 470 (amostras de touros Nelore); canaletas de 02 a 09 do blot inferior: 30 ug de proteínas de soro total dos animais de números 813, 1441, 1813, 1937, 1973, 3030, 3443 e 3983 (amostras de vacas Nelore). B) Quantificação de bandas obtidas em Western blot das amostras de soro total das amostras avaliadas na Figura 12A. O anticorpo primário usado foi IgM de camundongo anti-bcOBP diluído a 1:1000 e secundário foi o anticorpo IgM anti-IgM de camundongo diluído a 1:1000, revelados com ECL conforme instruções do fabricante. A curva padrão foi preparada de acordo com o descrito na seção 3.5 e a intensidade das bandas foi aferida por meio do programa Image $\mathbf{J}$. 
Com os resultados das figuras acima de 09 a 12, é possível concluir que touros e vacas em lactação de ambas as raças apresentam bcOBP. E que touros HPB apresentaram um aumento significativo quando comparados com touros Nelores (fig. 10. B), e com vacas em lactação HPB (fig. 11. B).

\subsubsection{Presença e analise semi-quantitativa de Western Blot da bcOBP em amostras} de saliva coletado de touros e vacas em lactação das raças Holandês e Nelore.

Ao realizar Western blot de amostras de saliva de vacas em lactação Nelore e HPB (fig. 13) podemos concluir que apenas vacas em lactação HPB apresentam bcOBP (fig. 13. A), e também apresentam um aumento significativo ( $\mathrm{P}=<0,001$, ver fig. 13. B).

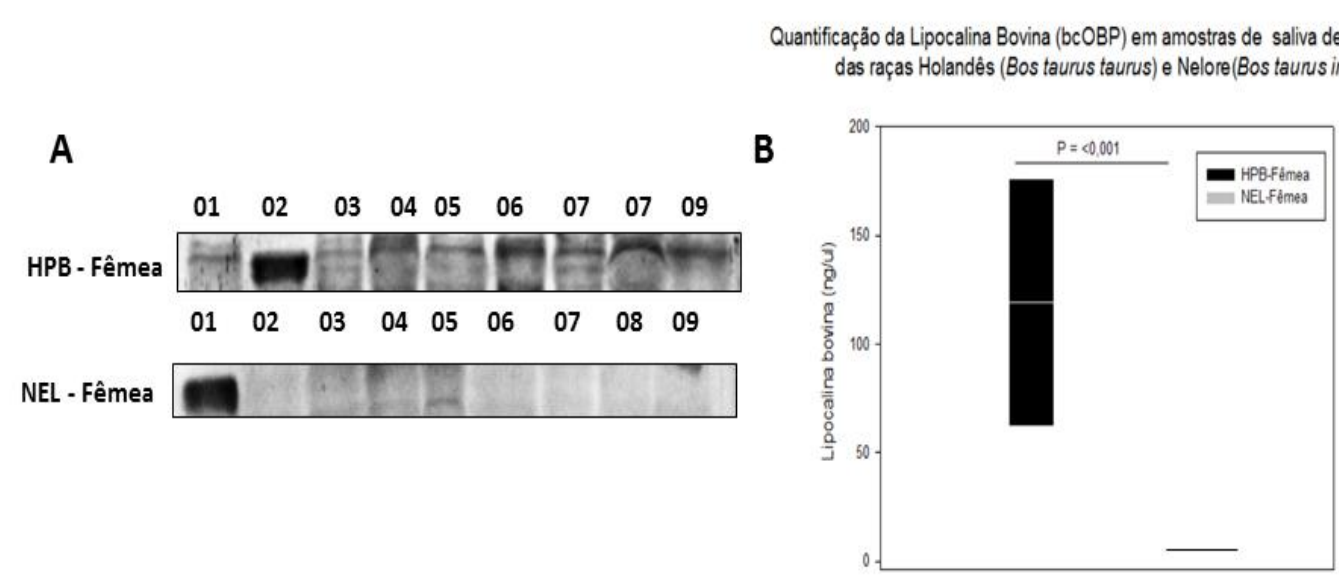

Figura 13: Detecção e quantificação de bcOBP por meio de Western Blot e de densitometria de Western blot de amostras de saliva de vacas em lactação das raças HPB e Nelore. A) Western blot de saliva de vacas reagidas com anticorpo monoclonal específico para bcOBP; canaleta 02 e 01 dos blots superior e inferior respectivamente: rbcOBP (2mg); canaletas de 01,03 a 09 do blot superior: 30 ug de proteínas de saliva dos animais de números 24, 38, 64, 67, 75, 98, 100 e 107 (amostras de vacas HPB); canaletas de 02 a 09 do blot inferior: 30 ug de proteínas de saliva dos animais de números 813, 1441, 1813, 1937, 1973, 3030, 3443 e 3983 (amostras de vacas Nelore). B) Quantificação de bandas obtidas em Western blot das amostras de saliva das amostras avaliadas na Figura 13A. O anticorpo primário usado foi IgM de camundongo anti-bcOBP diluído a 1:1000 e secundário foi o anticorpo IgM anti-IgM de camundongo diluído a 1:1000, revelados com ECL conforme instruções do fabricante. A curva padrão foi preparada de acordo com o descrito na seção 3.5 e a intensidade das bandas foi aferida por meio do programa Image $\mathrm{J}(\mathrm{P}=<001)$. 
De acordo com os resultados de Western blot de saliva entre touros Nelore e HPB na figura 14, podemos concluir que apenas touros HPB apresentam bcOBP (fig. 14.A) e demonstraram um aumento significativo ( $\mathrm{P}=0,021$, Fig. 14. B).

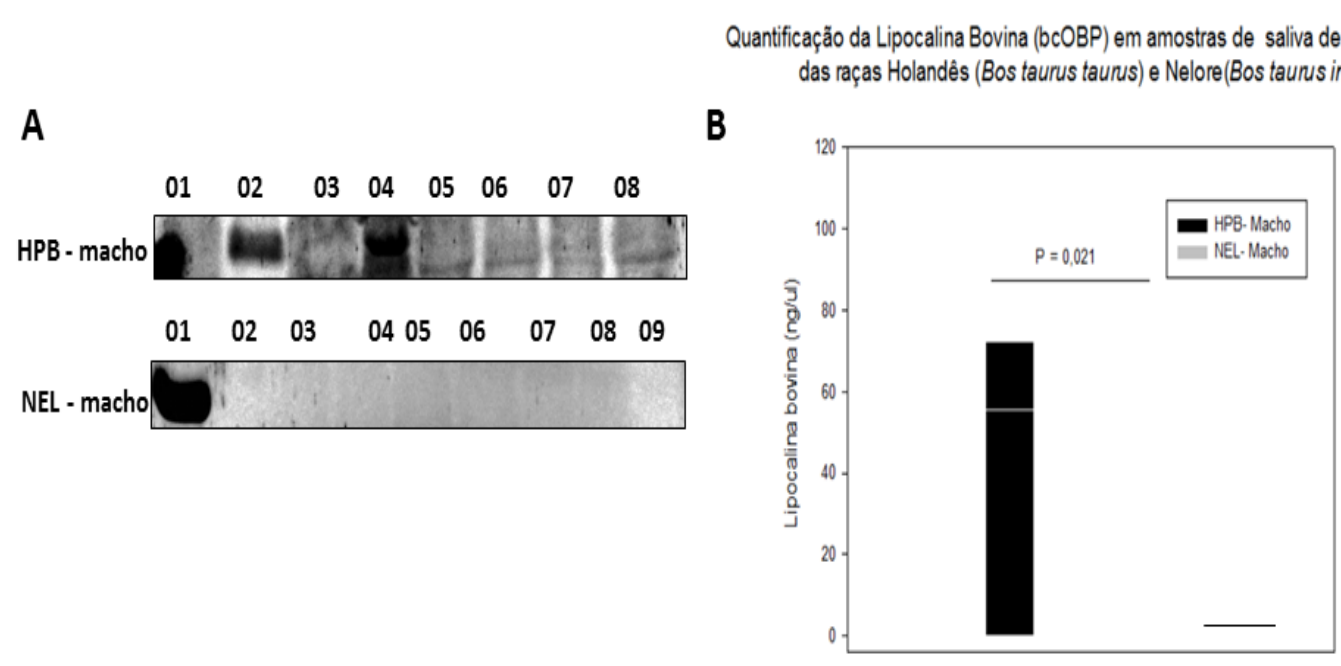

Figura 14: Detecção e quantificação de bcOBP por meio de Western Blot e de densitometria de Western blot de amostras saliva de touros raças HPB e Nelore. A) Western blot de saliva de touros reagidas com anticorpo monoclonal específico para bcOBP; canaleta 02 e 01 dos blots superior e inferior, respcetivamente: rbcOBP $(2 \mathrm{mg})$; canaletas de 01 , 03 a 09 do blot superior: 30 ug de proteínas de saliva dos animais de números 1518, 1522, 1523, 1532, 1536, 1537, 1539 (amostras de touros HPB); canaletas de 02 a 09 do blot inferior: 30 ug de proteínas de saliva dos animais de números 440, 442, 443, 444, 447, 456, 468, 470 (amostras de touros Nelore). B) Quantificação de bandas obtidas em Western blot das amostras de saliva das amostras avaliadas na Figura 14. A. O anticorpo primário usado foi IgM de camundongo anti-bcOBP diluído a 1:1000 e secundário foi o anticorpo IgM anti-IgM de camundongo diluído a 1:1000, revelados com ECL conforme instruções do fabricante. A curva padrão foi preparada de acordo com o descrito na seção 3.5 e a intensidade das bandas foi aferida por meio do programa Image $\mathbf{J}(\mathrm{P}=0,021)$.

Podemos concluir através da Figura 15, que touros e vacas em lactação apresentam bcOBP (fig. 15.A), que ocorreu um aumento significativo para vacas em lactação HPB em amostras de saliva (fig. 15.B, $\mathrm{P}=0,029$ ). 
A

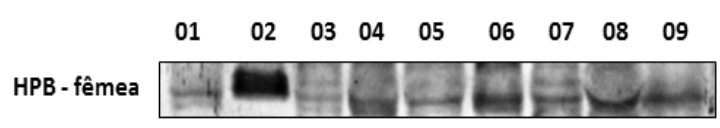

$\begin{array}{llllllll}01 & 02 & 03 & 04 & 05 & 06 & 07 & 08\end{array}$

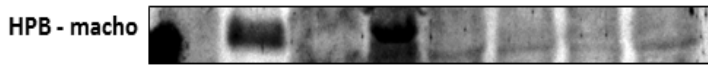

B

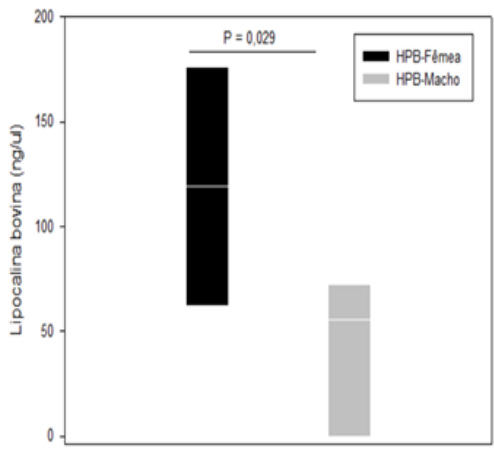

Figura 15: Detecção e quantificação de bcOBP por meio de Western Blot e de densitometria de Western blot de amostras saliva de touros e vacas da raça HPB. A) Western blot de saliva touros e vacas em lactação reagidas com anticorpo monoclonal específico para bcOBP; canaleta 02 dos blots superior e superior: rbcOBP $(2 \mathrm{mg})$; canaletas de 01, 03 a 09 do blot superior: 30 ug de proteínas de saliva dos animais de números 24, 38, 64, 67, 75, 98, 100 e 107 (amostras de vacas HPB); canaletas de 02 a 09 do blot inferior: 30 ug de proteínas de saliva dos animais de números 1518, 1522, 1523, 1532, 1536, 1537, 1539 (amostras de touros HPB); B) Quantificação de bandas obtidas em Western blot das amostras de saliva das amostras avaliadas na Figura 15. A. O anticorpo primário usado foi IgM de camundongo anti-bcOBP diluído a 1:1000 e secundário foi o anticorpo IgM anti-IgM de camundongo diluído a 1:1000, revelados com ECL conforme instruções do fabricante. A curva padrão foi preparada de acordo com o descrito na seção 3.5 e a intensidade das bandas foi aferida por meio do programa Image $\mathrm{J}(\mathrm{P}=0,029)$.

Considerando os resultados obtidos nas Figuras 13, 14 e 15 podem concluir que em amostras de saliva de touros (fig. 14. A) e vacas em lactação (fig. 15. A) da raça Nelore não apresentam bcOBP, e que existe um aumento significativo de bcOBP para touros (fig. 14. B) e vacas lactação (fig. 15.B) da raça HPB. E que entre amostras de saliva de touros e vacas em lactação da raça HPB ocorreu um aumento significativo para as vacas em lactação HPB (fig. 15). 


\subsubsection{Presença e analise semi-quantitativa de Western Blot da bcOBP em amostras de suor coletado de touros e vacas em lactação das raças Holandês e Nelore.}

Como podemos observar na Figura 16. A, a reatividade de proteínas do suor das vacas em lactação das raças HPB e Nelore com o anticorpo monoclonal específico para a bcOBP confirma que esta proteína está presente em nesse fluido. A quantificação das bandas da bcOBP por imagem $\mathrm{J}$ permitiu concluir que não existiam diferenças significativas entre as vacas dessas duas raças (fig. 16.B).

Quantificação da Lipocalina Bovina (bcOBP) em amostras de suor de bovinos fêmea das raça Holandês (Bos taurus taurus) e Nelore (Bos taurus indicus).
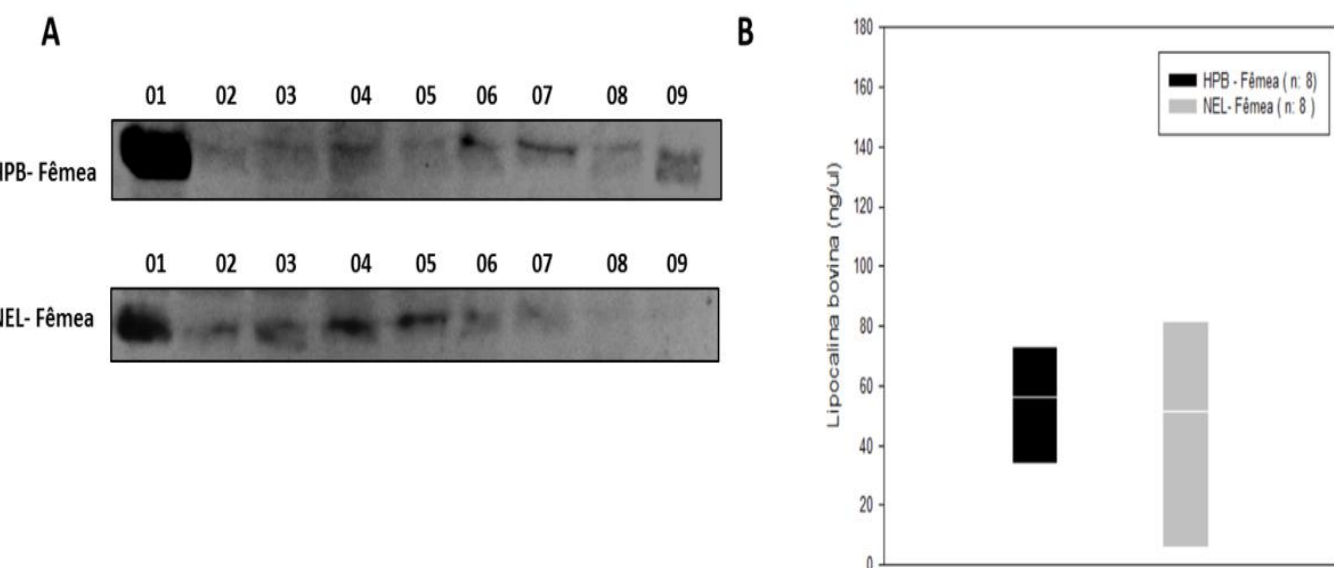

Figura 16: Detecção e quantificação de bcOBP por meio de Western Blot e de densitometria de Western blot de amostras de suor de vacas em lactação das raças HPB e Nelore. A) Western blot de suor de vacas reagidas com anticorpo monoclonal específico para bcOBP; canaleta 01 dos blots superior e inferior: rbcOBP $(2 \mathrm{mg})$; canaletas de 02 a 09 do blot superior: 15 ug de proteínas de suor dos animais de números 24, 38, 64, 67, 75, 98, 100 e 107 (amostras de vacas HPB); canaletas de 02 a 09 do blot inferior: 15 ug de proteínas de suor dos animais de números 813, 1441, 1813, 1937, 1973, 3030, 3443 e 3983 (amostras de vacas Nelore). B) Quantificação de bandas obtidas em Western blot das amostras de soro total das amsotras avaliadas na Figura 16A. O anticorpo primário usado foi IgM de camundongo antibcOBP diluído a 1:1000 e secundário foi o anticorpo $\operatorname{IgM}$ anti-IgM de camundongo diluído a 1:1000, revelados com ECL conforme instruções do fabricante. A curva padrão foi preparada de acordo com o descrito na seção 3.5 e a intensidade das bandas foi aferida por meio do programa Image J.

Por meio da Figura 16, podemos concluir que amostras de suor de touros Nelore e HPB apresentam bcOBP ( fig. 17. A), e ao quantificar as bandas positivas para bcOBP por image $\mathbf{J}$ podemos concluir que não ocorre diferença significativa entre os touros de ambas as raças (ver fig. 17. B). 
A

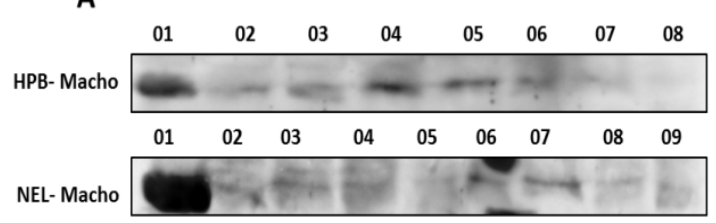

B

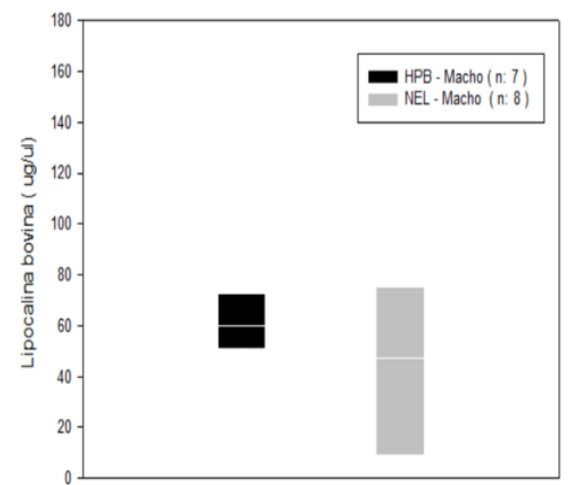

Figura 17: Detecção e quantificação de bcOBP por meio de Western Blot e de densitometria de Western blot de amostras suor de touros raças HPB e Nelore. A) Western blot de suor de touros reagidas com anticorpo monoclonal específico para bcOBP; canaleta 01 dos blots superior e inferior: rbcOBP (2mg); canaletas de 02 a 09 do blot superior: 15 ug de proteínas de suor dos animais de números 1518, 1522, 1523, 1532, 1536, 1537, 1539 (amostras de touros HPB); canaletas de 02 a 09 do blot inferior: 15 ug de proteínas de suor dos animais de números 440, 442, 443, 444, 447, 456, 468, 470 (amostras de touros Nelore). B) Quantificação de bandas obtidas em Western blot das amostras de suor das amostras avaliadas na Figura 17. A. O anticorpo primário usado foi IgM de camundongo anti-bcOBP diluído a 1:1000 e secundário foi o anticorpo IgM anti-IgM de camundongo diluído a 1:1000, revelados com ECL conforme instruções do fabricante. A curva padrão foi preparada de acordo com o descrito na seção 3.5 e a intensidade das bandas foi aferida por meio do programa Image J.

De acordo com a análise de Western blot na Figura 18 de amostras de suor de entre touros e vacas em lactação da raça HPB, é possível concluir que ambos apresentam bcOBP (fig. 18.A), e que não ocorre diferença significativa entre touros e vacas da raça HPB ao quantificar as bandas positivas para bcOBP por image $\mathrm{J}$ (fig. 18.B).

A

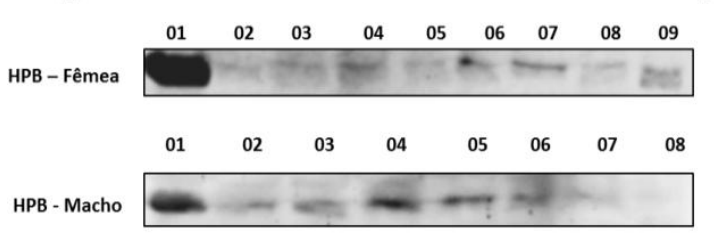

B

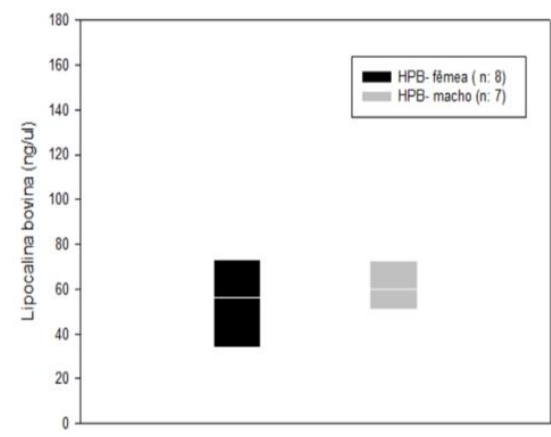

Figura 18: Detecção e quantificação de bcOBP por meio de Western blot e de densitometria de Western blot de amostras suor de touros e vacas da raça HPB. A) Western blot de suor de touros e vacas em lactação reagidas com anticorpo monoclonal específico para bcOBP; canaleta 01 dos blots superior e superior: rbcOBP (2mg); canaletas de 
02 a 09 do blot superior: 15 ug de proteínas de suor dos animais de números 24, 38, 64, 67, 75 , 98, 100 e 107 (amostras de vacas HPB); canaletas de 02 a 09 do blot inferior: 15ug de proteínas de suor dos animais de números 1518, 1522, 1523, 1532, 1536, 1537, 1539 (amostras de touros HPB); B) Quantificação de bandas obtidas em Western blot das amostras de suor das amostras avaliadas na Figura 18A. O anticorpo primário usado foi IgM de camundongo antibcOBP diluído a 1:1000 e secundário foi o anticorpo $\operatorname{IgM}$ anti-IgM de camundongo diluído a 1:1000, revelados com ECL conforme instruções do fabricante. A curva padrão foi preparada de acordo com o descrito na seção 3.5 e a intensidade das bandas foi aferida por meio do programa Image $\mathbf{J}$.

Considerando a comparação entre amostras de suor de touros e vacas em lactação da raça Nelore na Figura 19, conclui que ambos apresentam bcOBBP no suor (fig. 19.A), e ao quantificar as bandas positivas para bcOBP por meio do programa image J não foi encontrada diferença significativa (fig. 19.B).

Quantificação da Lipocalina Bovina (bcOBP) em amostras de suor de bovinos fêmea e macho das raça Nelore (Bos taurus indicus).

A

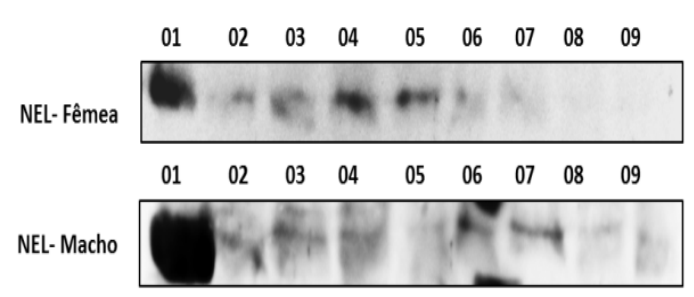

$B$

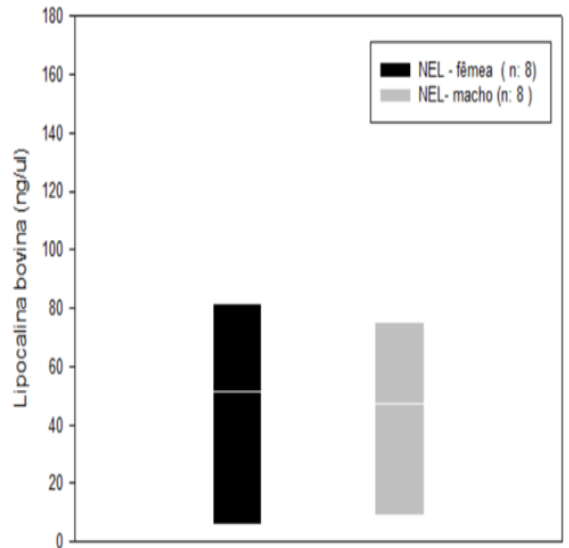

Figura 19: Detecção e quantificação de bcOBP por meio de Western Blot e de densitometria de Western blot de amostras suor de touros e vacas em lactação da raça Nelore. A) Western blot de suor touros reagidas com anticorpo monoclonal específico para bcOBP; canaleta 01 dos blots superior e inferior: rbcOBP (2mg); canaletas de 02 a 09 do blot superior: 15 ug de proteínas de soro total dos animais de números 813, 1441, 1813, 1937, 1973, 3030, 3443 e 3983 (amostras de vacas Nelore); canaletas de 02 a 09 do blot inferior: 15ug de proteínas de soro total dos animais de números 440, 442, 443, 444, 447, 456, 468, 470 (amostras de touros Nelore). B) Quantificação de bandas obtidas em Western blot das amostras de suor das amostras avaliadas na Figura 19. A. O anticorpo primário usado foi IgM de camundongo anti-bcOBP diluído a 1:1000 e secundário foi o anticorpo $\operatorname{IgM}$ anti-IgM de camundongo diluído a 1:1000, revelados com ECL conforme instruções do fabricante. A curva padrão foi preparada de acordo com o descrito na seção 3.5 e a intensidade das bandas foi aferida por meio do programa Image $\mathrm{J}$.

Em resumo com os resultados das Figuras acima de 16, 17, 18 e 19 é possível concluir que touros e vacas em lactação de ambas as raças apresentam bcOBP. E que ao 
quantificar as bandas positivas para bcOBP através do Image $\mathrm{J}$, não ocorre diferença significativa entre touros e vacas das raças Nelore e HPB (fig 16. B e 17.B), e também entre touros e vacas da mesma raça (fig.18.B e 19.B).

\subsubsection{Presença e analise semi-quantitativa de Western Blot da bcOBP em amostras} de secreção nasal coletado de touros e vacas em lactação das raças Holandês e Nelore.

Como podemos observar na Figura 20, ao avaliar os resultados de Western Blot de secreção nasal de vacas em lactação das raças Nelore e HPB, concluímos que apenas vacas HPB apresentam bcOBP (fig.20. A). E ao quantificar as bandas positivas para bcOBP por image $\mathrm{J}$ o resultado demonstrou um aumento significativo para vacas em lactação da raça HPB (P=0,002, fig. 20. B).

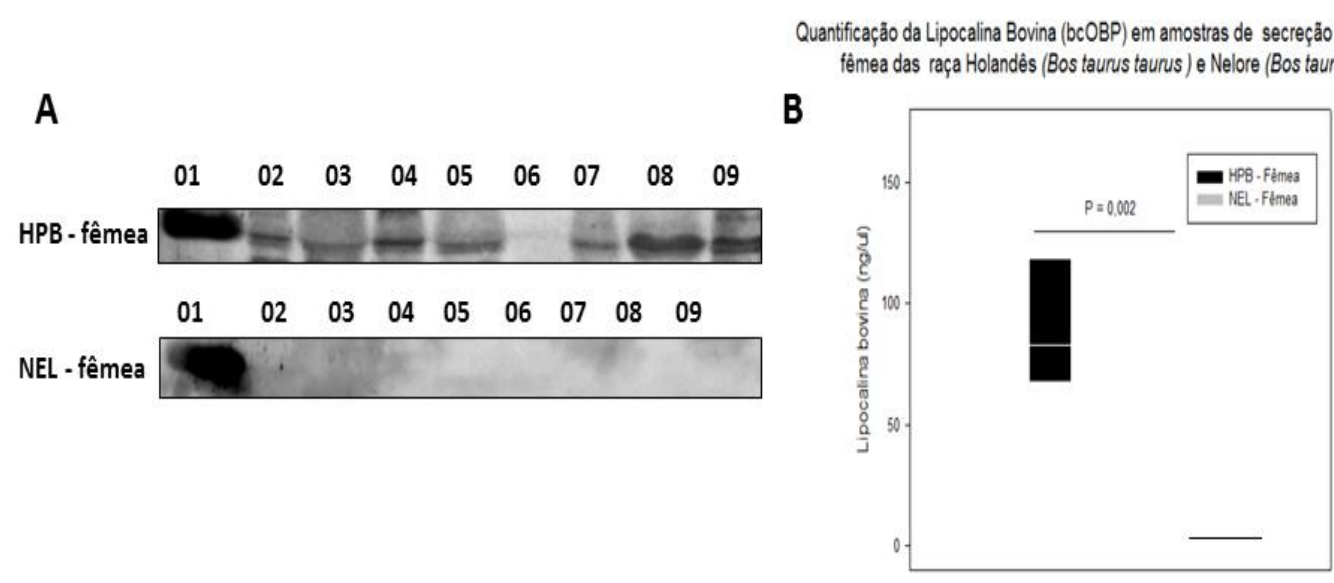

Figura 20: Detecção e quantificação de bcOBP por meio de Western Blot e de densitometria de Western blot de amostras de secreção nasal de vacas em lactação das raças HPB e Nelore. A) Western blot de secreção nasal de vacas reagidas com anticorpo monoclonal específico para bcOBP; canaleta 01 dos blots superior e inferior: rbcOBP $(2 \mathrm{mg})$; canaletas de 02 a 09 do blot superior: 30 ug de proteínas de secreção nasal dos animais de números 24, 38, 64, 67, 75, 98, 100 e 107 (amostras de vacas HPB); canaletas de 02 a 09 do blot inferior: 30 ug de proteínas de secreção nasal dos animais de números 813, 1441, 1813, 1937, 1973, 3030, 3443 e 3983 (amostras de vacas Nelore). B) Quantificação de bandas obtidas em Western blot das amostras de secreção nasal das amsotras avaliadas na Figura 20. A. O anticorpo primário usado foi $\operatorname{IgM}$ de camundongo anti-bcOBP diluído a 1:1000 e secundário foi o anticorpo IgM anti-IgM de camundongo diluído a 1:1000, revelados com ECL conforme instruções do fabricante. A curva padrão foi preparada de acordo com o descrito na seção 3.5 e a intensidade das bandas foi aferida por meio do programa Image $\mathrm{J}$. 
Com os resultados de amostras de secreção nasal entre touros das raças Nelore e HPB na Figura 21, podemos concluir que existe uma maior presença de bcOBP (fig. 21. A) e um aumento significativos de bcOBP para touros da raça HPB ( $\mathrm{P}=0,009$, fig. 21.B).

Quantificação da Lipocalina Bovina (bcOBP) em amostras de secreção nasal de bovinos machos das raça Holandês (Bos taurus taurus) e Nelore (Bos taurus indicus).

A

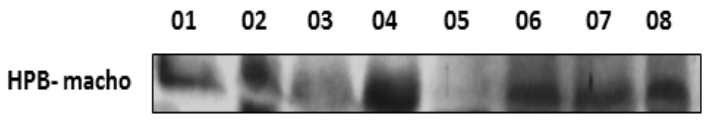

$\begin{array}{lllllllll}01 & 02 & 03 & 04 & 05 & 06 & 07 & 08 & 09\end{array}$

NEL macho

B

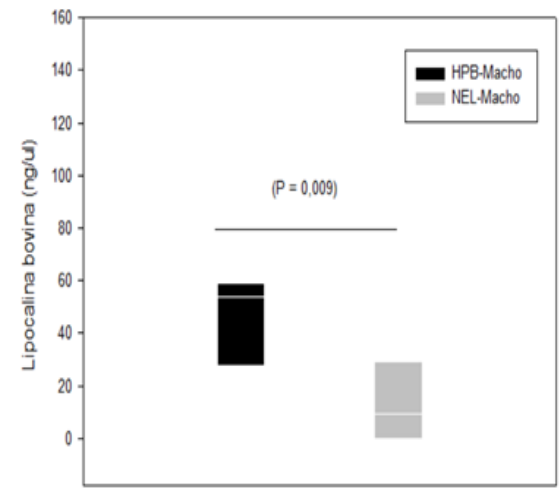

Figura 21: Detecção e quantificação de bcOBP por meio de Western Blot e de densitometria de Western Blot de amostras secreção nasal de touros raças HPB e Nelore. A) Western blot de secreção nasal de touros reagidas com anticorpo monoclonal específico para bcOBP; canaleta 01 dos blots superior e inferior: rbcOBP (2mg); canaletas de 02 a 09 do blot superior: 30 ug de proteínas de secreção nasal dos animais de números 1518, 1522, 1523, 1532 , 1536, 1537, 1539 (amostras de touros HPB); canaletas de 02 a 09 do blot inferior: 30ug de proteínas de secreção nasal dos animais de números 440, 442, 443, 444, 447, 456, 468, 470 (amostras de touros Nelore). B) Quantificação de bandas obtidas em Western Blot das amostras de secreção nasal das amostras avaliadas na Figura 21. A. O anticorpo primário usado foi IgM de camundongo anti-bcOBP diluído a 1:1000 e secundário foi o anticorpo IgM anti-IgM de camundongo diluído a 1:1000, revelados com ECL conforme instruções do fabricante. A curva padrão foi preparada de acordo com o descrito na seção 3.5 e a intensidade das bandas foi aferida por meio do programa Image $\mathrm{J}(\mathrm{P}=0,009)$.

Conforme podemos ver na Figura 22, os resultados permite concluir que touros e vacas em lactação da raça HPB apresentam bcOBP (fig. 22.A), e que entre as bandas positivas para bcOBP quantificadas por image $\mathrm{J}$ não existe diferença significativa ( fig. 22. B). 
A

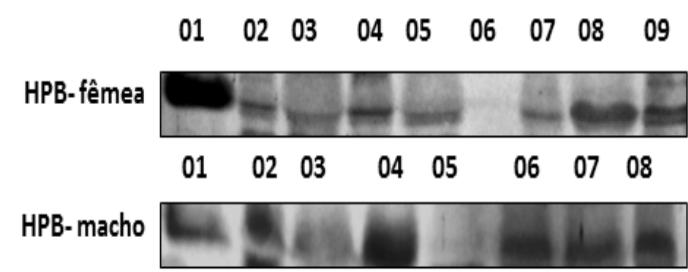

B

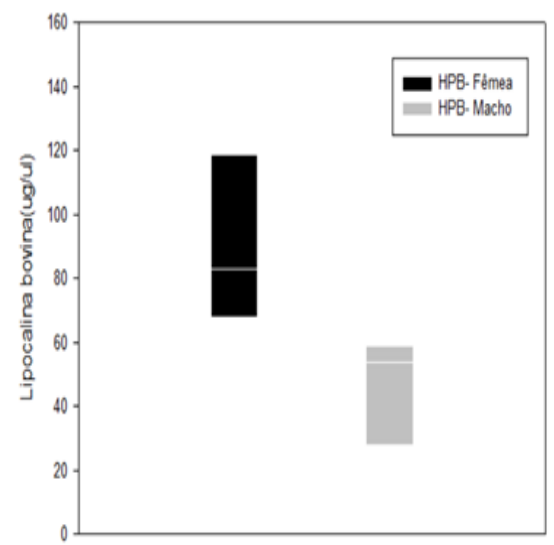

Figura 22: Detecção e quantificação de bcOBP por meio de Western Blot e de densitometria de Western blot de amostras secreção nasal de touros e vacas da raça HPB. A) Western blot de secreção nasal de touros e vacas em lactação reagidas com anticorpo monoclonal específico para bcOBP; canaleta 01 dos blots superior e superior: rbcOBP $(2 \mathrm{mg})$; canaletas de 02 a 09 do blot superior: 30 ug de proteínas de suor dos animais de números 24, 38, 64, 67, 75, 98, 100 e 107 (amostras de vacas HPB); canaletas de 02 a 09 do blot inferior: 30ug de proteínas de suor dos animais de números 1518, 1522, 1523, 1532, 1536, 1537, 1539 (amostras de touros HPB); B) Quantificação de bandas obtidas em Western Blot das amostras de secreção nasal das amostras avaliadas na Figura 22A. O anticorpo primário usado foi IgM de camundongo anti-bcOBP diluído a 1:1000 e secundário foi o anticorpo IgM anti-IgM de camundongo diluído a 1:1000, revelados com ECL conforme instruções do fabricante. A curva padrão foi preparada de acordo com o descrito na seção 3.5 e a intensidade das bandas foi aferida por meio do programa Image $\mathrm{J}$.

De acordo com a análise de Western blot de secreção nasal na Figura 23, concluímos que alguns touros da raça Nelore apresentam bcOBP ( fig. 23. A), e que não apresentam diferença significativa entre os sexos (fig. 23. B).

Quantificação da Lipocalina Bovina (bcOBP) em amostras de secreção nasal de bovinos fêmea e macho das raça Nelore (Bos taurus indicus).

A

$\begin{array}{lllllllll}01 & 02 & 03 & 04 & 05 & 06 & 07 & 08 & 09\end{array}$

NEL - fêmea

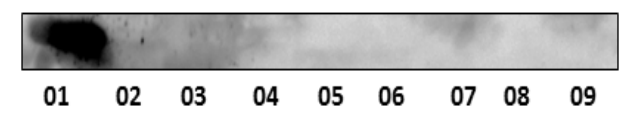

NEL - macho
B

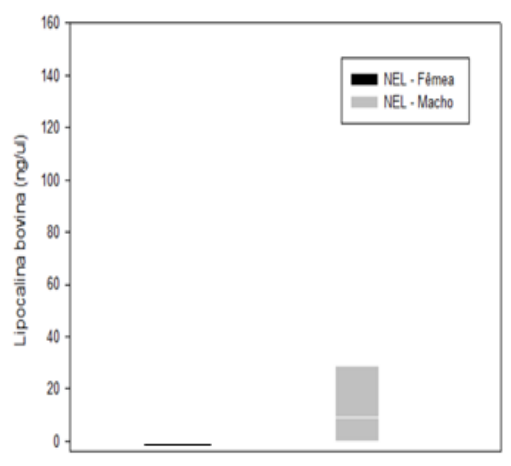

Figura 23: Deteç̧ão e quantificação de bcOBP por meio de Western Blot e de densitometria de Western Blot de amostras secreção nasal de touros e vacas em lactação 
da raça Nelore. A) Western blot de secreção nasal de touros reagidas com anticorpo monoclonal específico para bcOBP; canaleta 01 dos blots superior e inferior: rbcOBP $(2 \mathrm{mg})$; canaletas de 02 a 09 do blot superior: $30 \mathrm{ug}$ de proteínas de soro total dos animais de números 813, 1441, 1813, 1937, 1973, 3030, 3443 e 3983 (amostras de vacas Nelore); canaletas de 02 a 09 do blot inferior: 30ug de proteínas de soro total dos animais de números 440, 442, 443, 444, 447, 456, 468, 470 (amostras de touros Nelore). B) Quantificação de bandas obtidas em Western Blot das amostras de secreção nasal das amostras avaliadas na Figura 23A. O anticorpo primário usado foi $\operatorname{IgM}$ de camundongo anti-bcOBP diluído a 1:1000 e secundário foi o anticorpo IgM anti-IgM de camundongo diluído a 1:1000, revelados com ECL conforme instruções do fabricante. A curva padrão foi preparada de acordo com o descrito na seção 3.5 e a intensidade das bandas foi aferida por meio do programa Image $\mathrm{J}$.

Com os resultados das figuras acima 20 a 23 em amostras de secreção nasal, é possível concluir que vacas da raça Nelore não apresentam bcOBP (fig.20.A), e as vacas em lactação (fig. 20.A) e os touros (fig. 21.A) da raça HPB apresentam bcOBP. Com os resultados de quantificação das bandas positivas para bcOBP por meio do image J, podemos concluir que vacas em lactação (fig. 20.B) e touros (fig. 21.B) da raça HPB tiveram um aumento significativo. E entre indivíduos da mesma raça, porém de sexo diferente não ocorre diferença significativa (fig. 22.B e 23.B).

\subsubsection{Presença e analise semi-quantitativa de Western Blot da bcOBP em amostras de urina coletado de touros e vacas em lactação das raças Holandês e Nelore.}

Considerando o resultado da Figura 24, podemos concluir que touros e vacas em lactação de ambas as raças não apresentam bcOBP na urina.

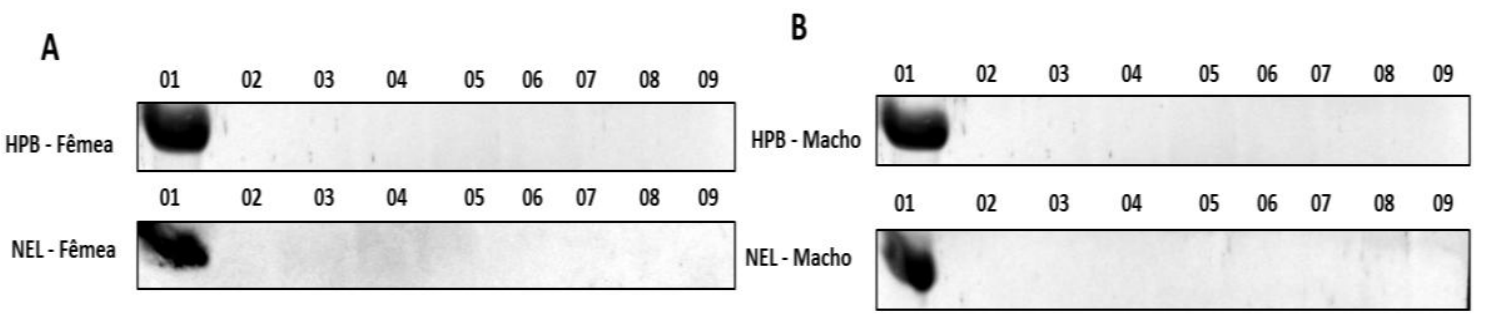

Figura 24: Deteç̧ão e quantificação de bcOBP por meio de Western Blot e de densitometria de Western Blot de amostras de urina de vacas em lactação e touros das raças HPB e Nelore. A) Western blot de urina de vacas reagidas com anticorpo monoclonal específico para bcOBP; canaleta 01 dos blots superior e inferior: rbcOBP (2mg); canaletas de 02 a 09 do blot superior: 15 ug de proteínas de urina dos animais de números $24,38,64,67,75,98$, 100 e 107 (amostras de vacas HPB); canaletas de 02 a 09 do blot inferior: 15 ug de proteínas de 
urina dos animais de números 813, 1441, 1813, 1937, 1973, 3030, 3443 e 3983 (amostras de vacas Nelore). B) Western blot de urina de touros reagidas com anticorpo monoclonal específico para bcOBP; canaleta 01 dos blots superior e inferior: rbcOBP (2mg); canaletas de 02 a 09 do blot superior: 15 ug de proteínas de secreção nasal dos animais de números 1518, 1522, 1523, 1532, 1536, 1537, 1539 (amostras de touros HPB); canaletas de 02 a 09 do blot inferior: 15 ug de proteínas de urina dos animais de números 440, 442, 443, 444, 447, 456, 468, 470 (amostras de touros Nelore). O anticorpo primário usado foi IgM de camundongo anti-bcOBP diluído a 1:1000 e secundário foi o anticorpo IgM anti-IgM de camundongo diluído a 1:1000, revelados com ECL conforme instruções do fabricante.

\subsection{Presença da lipocalina bovina (bcOBP) em pele de bovinos por meio de imuno- histoquímica touros e vacas em lactação das raças Holandês e Nelore.}

Com os resultados de imuno-histoquímica na figura $25 \mathrm{~A}-\mathrm{B}$, podemos concluir que vacas em lactação da raça HPB tem uma maior presença de bcOBP na pele (marcação em marrom, indicada por setas), quando comparados com vacas em lactação da raça Nelore.

De acordo com a imuno-histoquímica na figura 26, concluímos que touros HPB apresentam uma maior marcação para bcOBP (fig. 26.A) que os touros da raça Nelore (fig. 26. B). 
A
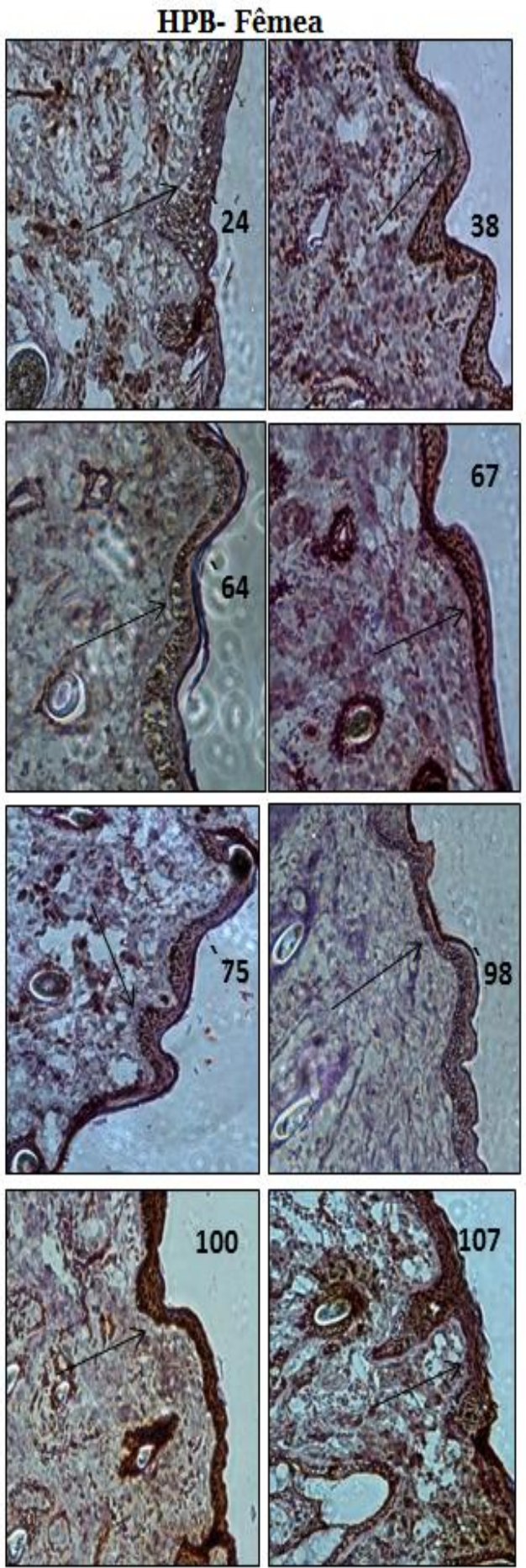

B
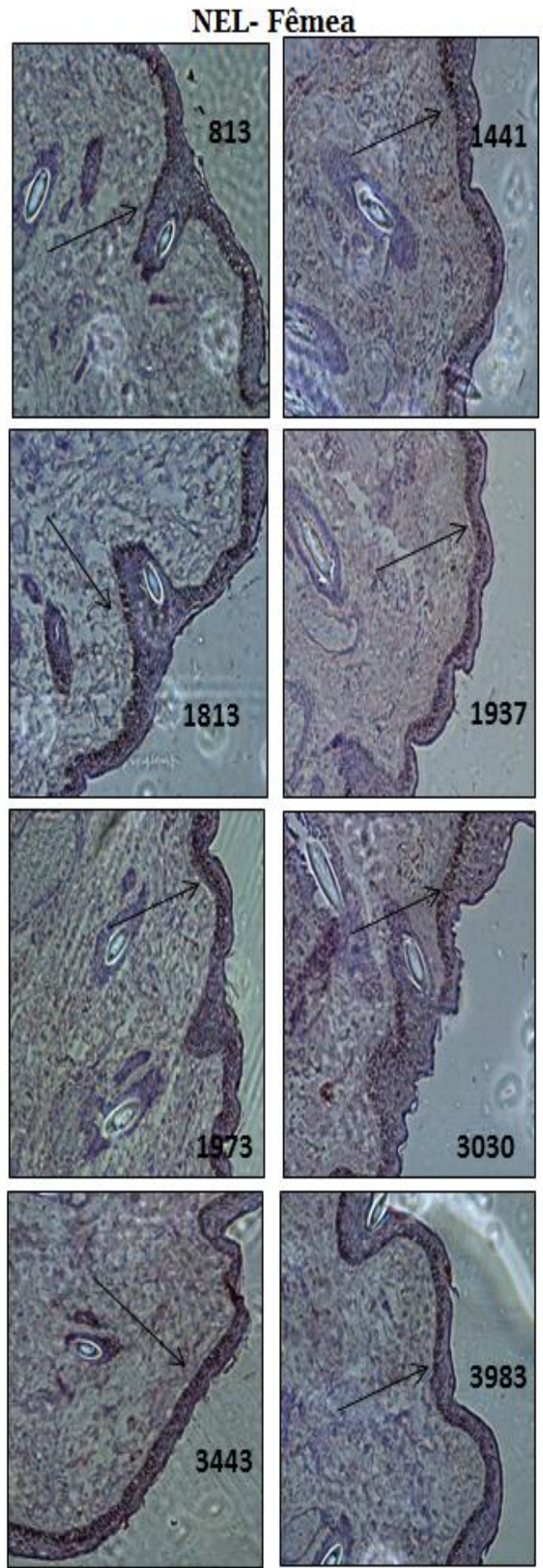

Figura 25: Presença da Lipocalina em biópsia de pele de vacas em lactação das raças HPB e Nelore. Cortes de imuno-histoquímica de Pele, lente 20X. A) Vacas em lactação da raça HPB, número dos animais utilizados no experimento: $24,38,64,67,75,98,100,107$. B) vacas em lactação da raça Nelore, número dos animais utilizados no experimento: 813, 1441, 1813, 1937, 1973, 3030,3443 e 3983. Para realização da imuno-histoquímica o anticorpo primário usado foi IgM de camundongo anti-bcOBP diluído a 1:50 e secundário foi o anticorpo IgM anti-IgM de camundongo diluído a 1:50, revelados com DAD conforme instruções do fabricante, contra corado com hematoxilina. As setas contidas na imagem indicam o local marcado. 
A
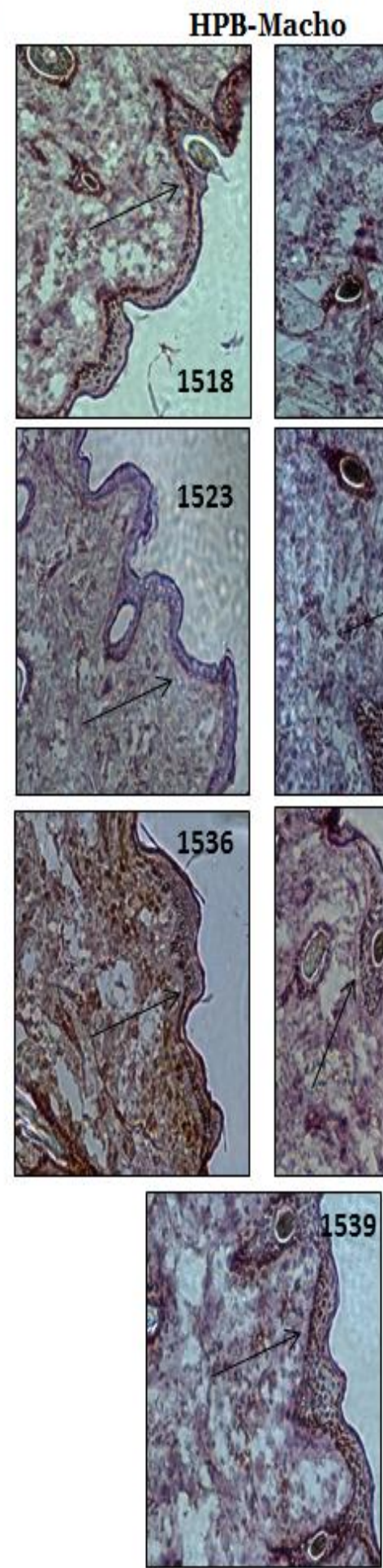

B
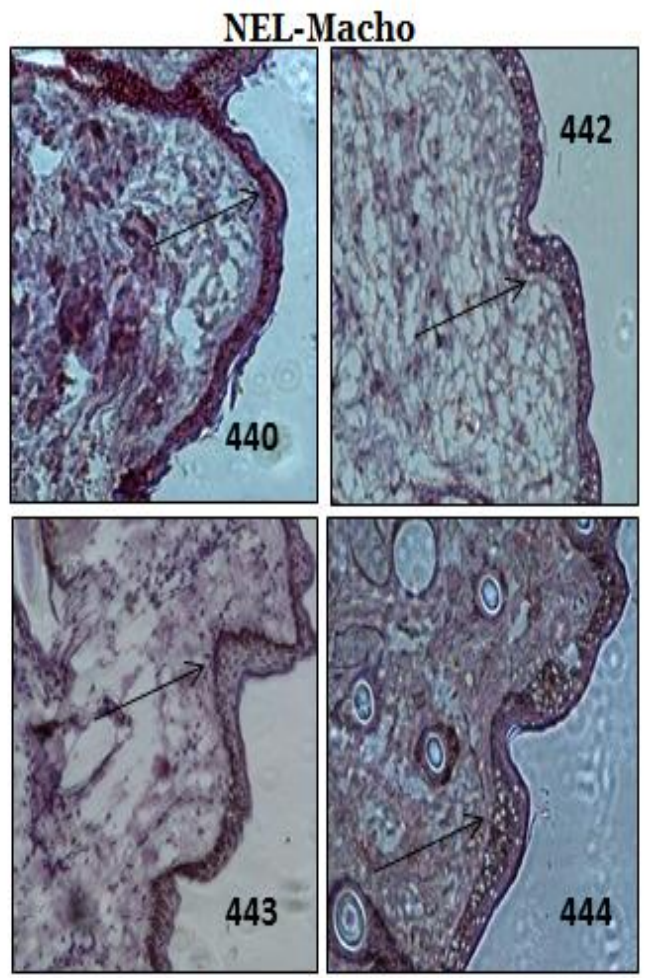

1532
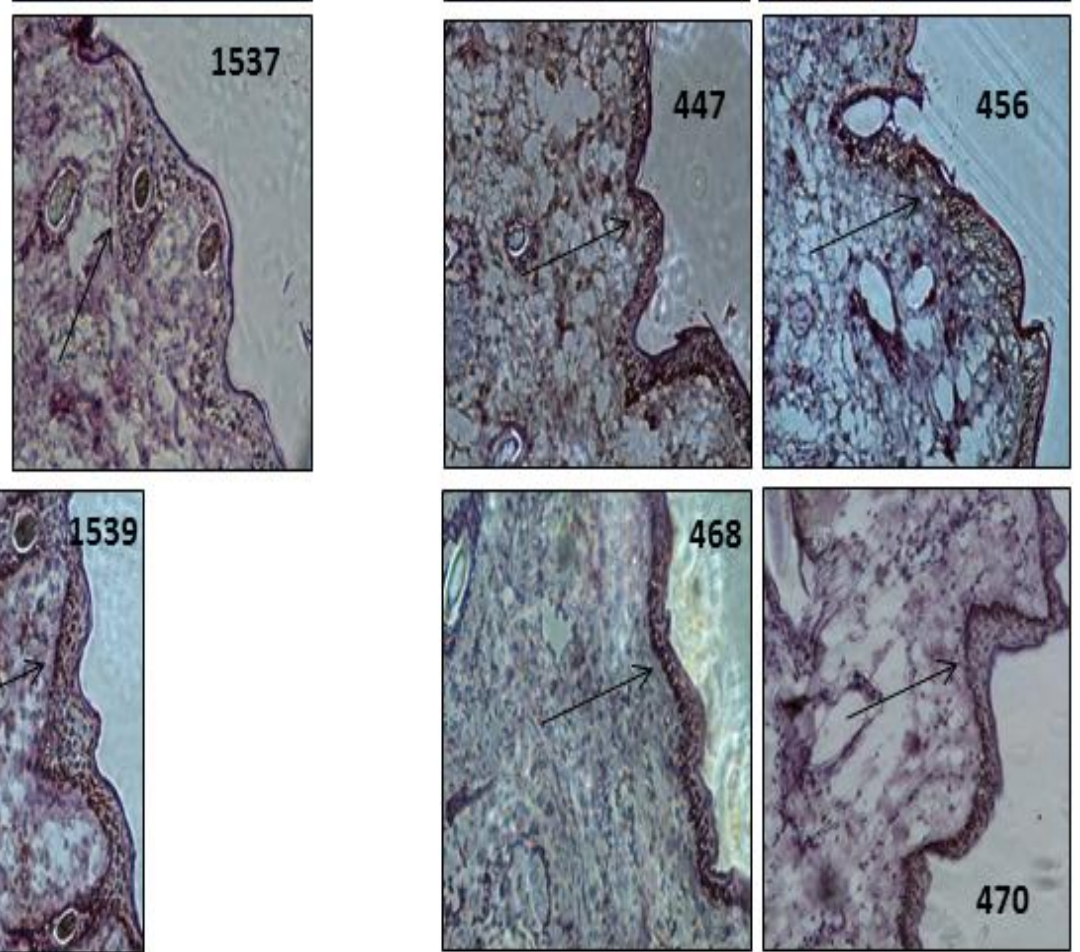

Figura 26: Presença da Lipocalina em biópsia de pele de touros das raças HPB e Nelore. Cortes de imuno-histoquímica de Pele, lente 20X. A) Touros da raça HPB, número dos animais utilizados no experimento: 1518; 1522; 1523; 1532; 1536; 1537 e 1539 . B) Touros da raça Nelore, número dos animais utilizados no experimento: 440; 442; 443; 444; 447; 456; 468 e 470. Para realização da imuno-histoquímica o anticorpo primário usado foi IgM de camundongo anti-bcOBP diluído a 1:50 e secundário foi o anticorpo IgM anti-IgM de camundongo diluído a 1:50, revelados com DAD conforme instruções do fabricante, contra corado com hematoxilina. As setas contidas na imagem indicam o local marcado. 
A Figura 27 (A-B) nos permite concluir que biópsias de pele de touros e vacas em lactação da raça HPB apresentam bcOBP, porém ocorre uma maior presença de bcOBP (marcação em marrom, indicada por setas) em vacas em lactação HPB quando comparadas com touros HPB.

Os resultados da figura 28 (A-B) demonstraram que ambos os sexos da raça Nelore apresentam bcOBP, e que possivelmente não ocorre diferença na presença da bcOBP na pele de touros e vacas da raça Nelore. 
A
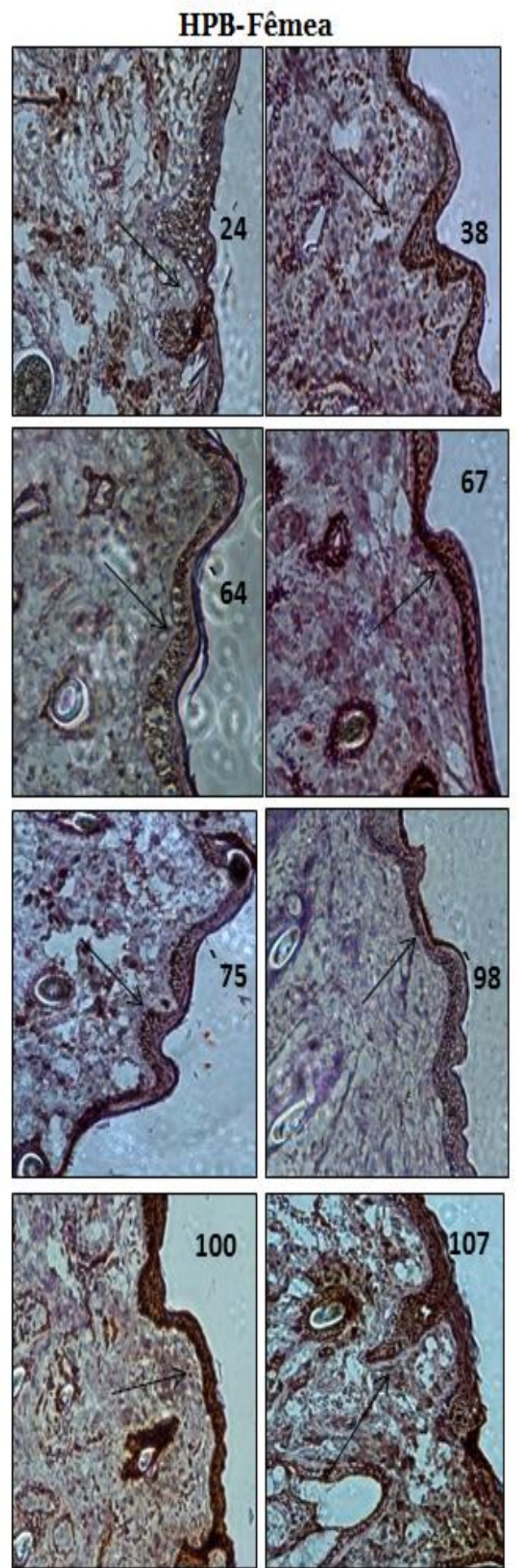

B
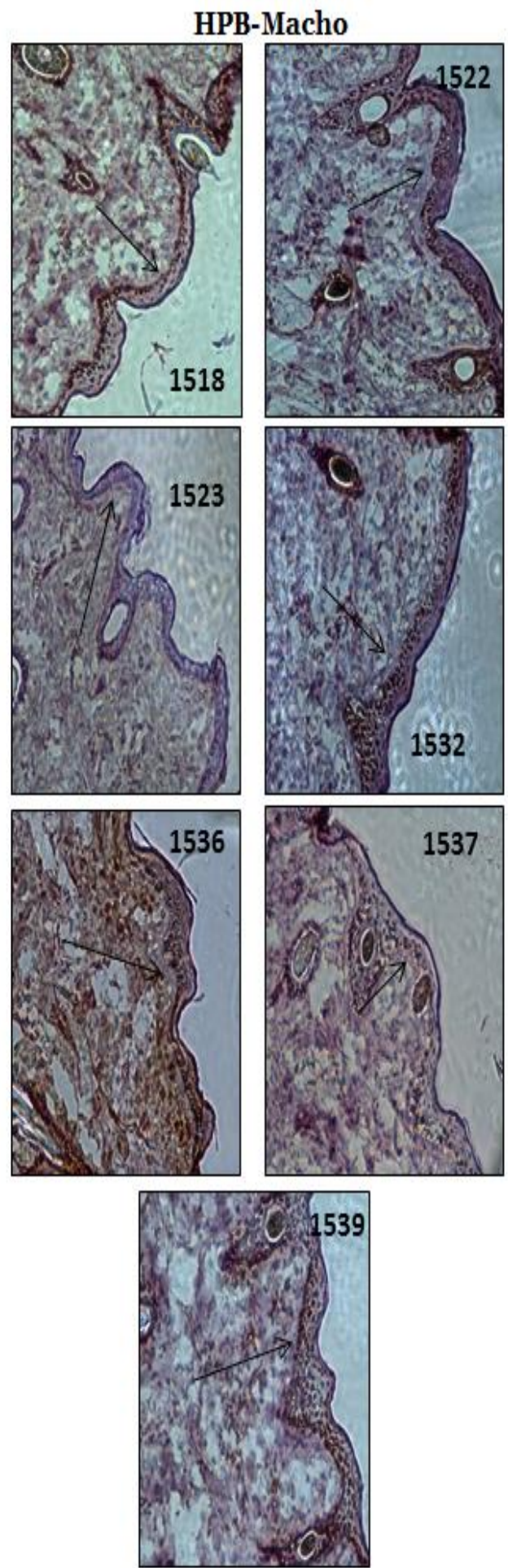

Figura 27: Presença da Lipocalina em biópsia de pele de vacas em lactação e touros da raça HPB. Cortes de imuno-histoquímica de Pele, lente 20X. A) Vacas em lactação HPB números dos animais utilizados no experimento: 24; 38; 64; 67; 75; 98; 100 e 107). B) Touros da raça $\mathrm{HPB}$, número dos animais utilizados no experimento: 1518; 1522; 1523; 1532; 1536;1537 e 1539. Para realização da imuno-histoquímica o anticorpo primário usado foi IgM de camundongo anti-bcOBP diluído a 1:50 e secundário foi o anticorpo $\operatorname{IgM}$ anti-IgM de camundongo diluído a 1:50, revelados com DAD conforme instruções do fabricante, contra corado com hematoxilina. As setas contidas na imagem indicam o local marcado. 
A
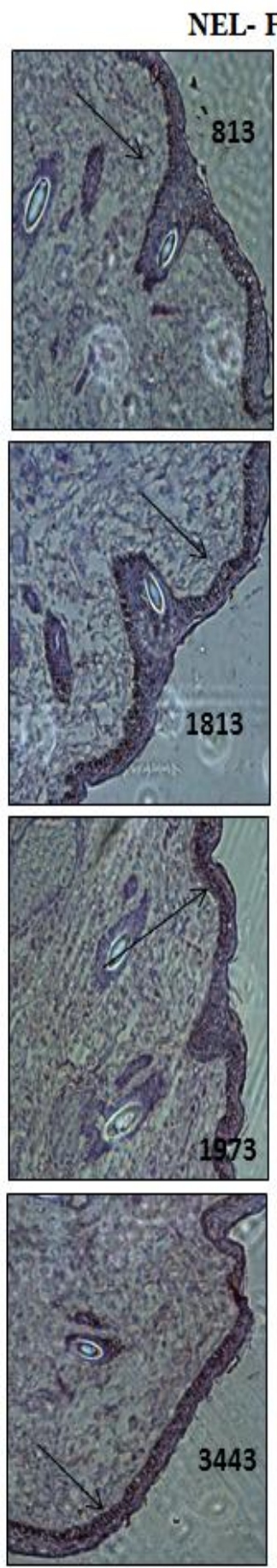
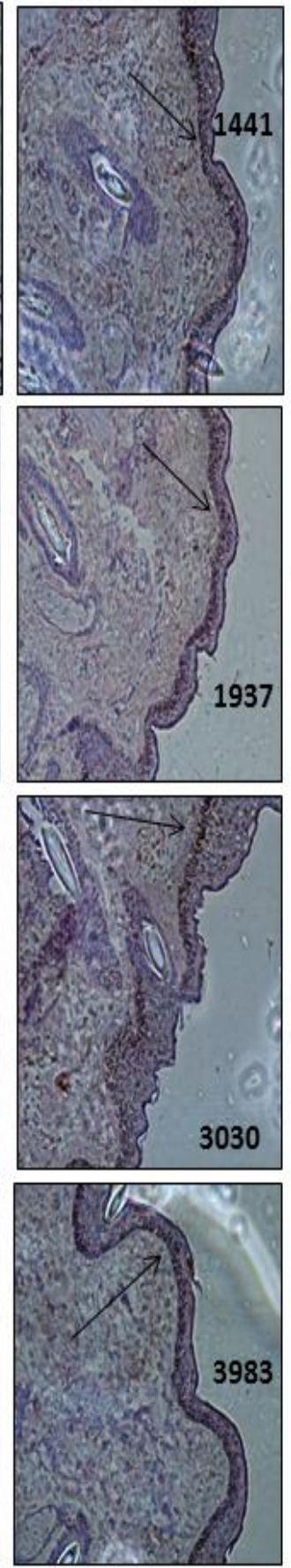

B
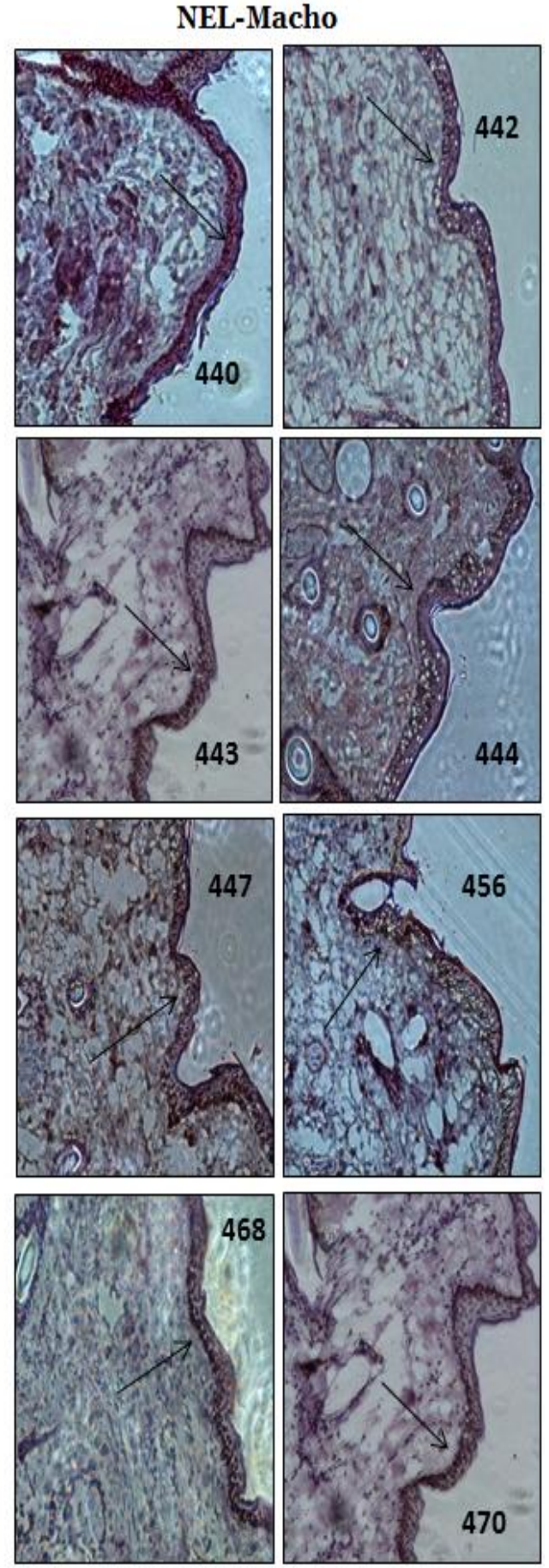

Figura 28: Presença da Lipocalina em biópsia de pele de vacas em lactação e touros da raça Nelore. Cortes de imuno-histoquímica de Pele, lente 20X. A) Vacas em lactação HPB da raca Nelore, número dos mais utilizados no experimento: $813 ; 1441 ; 1813 ; 1937 ; 1973$; 3030; 3443 e 3983. B) Touros da raça Nelore, número dos animais utilizados no experimento: 440;442; 443; 444; 447; 456; 468 e 470. . Para realização da imuno-histoquímica o anticorpo primário usado foi IgM de camundongo anti-bcOBP diluído a 1:50 e secundário foi o anticorpo IgM anti-IgM de camundongo diluído a 1:50, revelados com DAD conforme instruções do fabricante, contra corado com hematoxilina. As setas contidas na imagem indicam o local marcado. 
Em resumo, com os resultados de imuno-histoquímica das figuras 25 a 28, podemos concluir que touros e vacas em lactação das raças Nelore e Holandês apresentam bcOBP, porém existe uma maior presença de bcOBP na pele de touros e vacas em lactação da raça HPB(fig. 25 e 26). E quando avaliados os diferentes sexos da mesma raça é possível concluir que vacas em lactação HPB apresentam mais bcOBP na pele que touros HPB (fig. 27).

\subsection{Produção do anticorpo policlonal anti-lipocalina (IgY anti-lipocalin).}

Para quantificar a bcOBP por ELISA foi escolhido um peptídeo de proteínas presente em bovinos da família da lipocalina (Tabela 01).

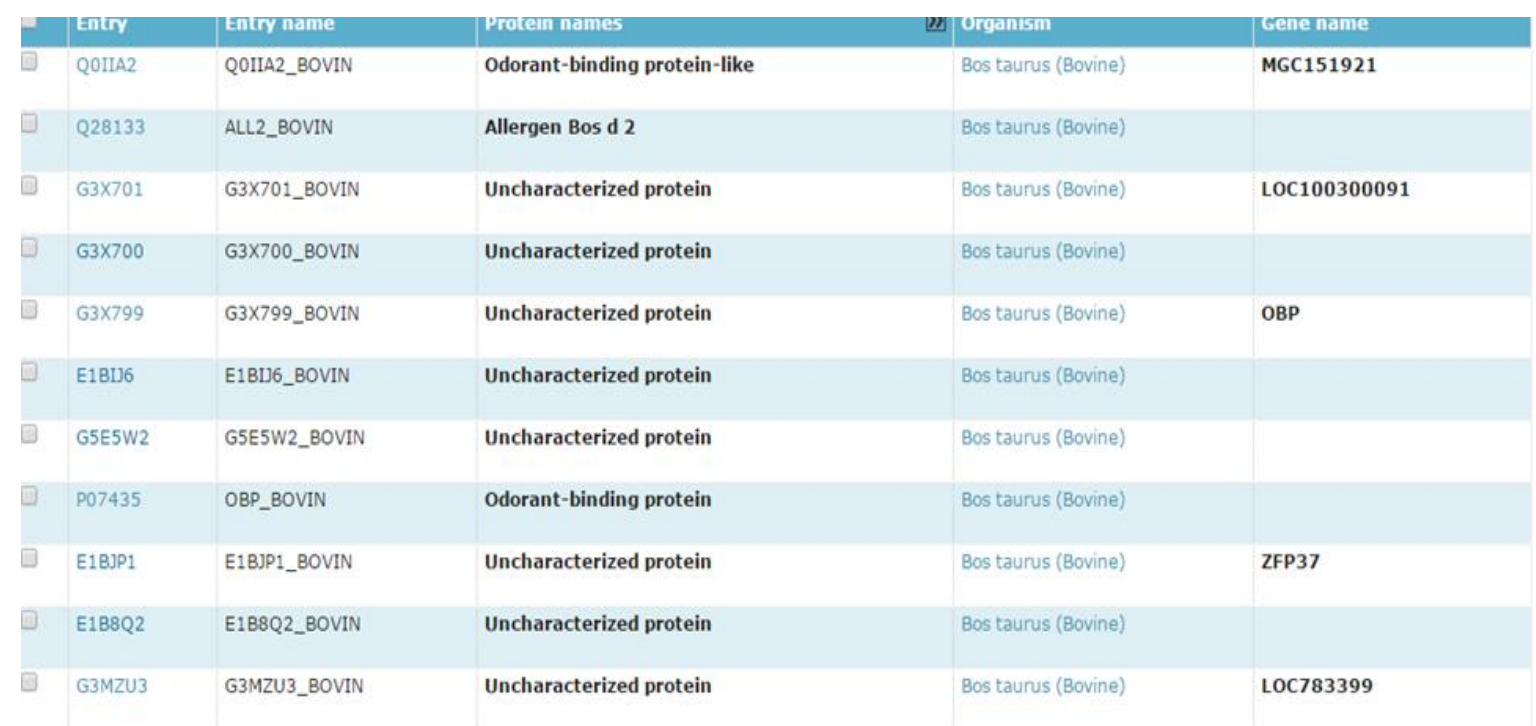

Tabela 01: Lipocalina presente em bovinos utilizadas para o alinhamento através do site uniprot para escolha do peptídeo.

Abaixo segue os passos utilizados para confirmar a produção do anticorpo IgY anti- Lipocalin (peptídeo escolhido).

\subsubsection{Peptídeo escolhido para imunização da galinha.}

Para produção do anticorpo policlonal específico para bcOBP, foi feito uma busca na base de dados do site Uni prot (http://www.uniprot.org) de todas a proteínas pertencentes a família da lipocalina (conforme descrito na secao 3.7). Posteriormente, foi feito um alinhamento, e a partir desse alinhamento foram escolhidas três sequências 
e destas três sequências, foi escolhido apenas a sequência 01 (QETPAEIDPSKVVGEWRTIYAAADNKEKIVEGGPLRCYNR), pois acreditamos que esta sequência é a que apresenta maior similaridade entre estas proteínas. (Tabela 02).
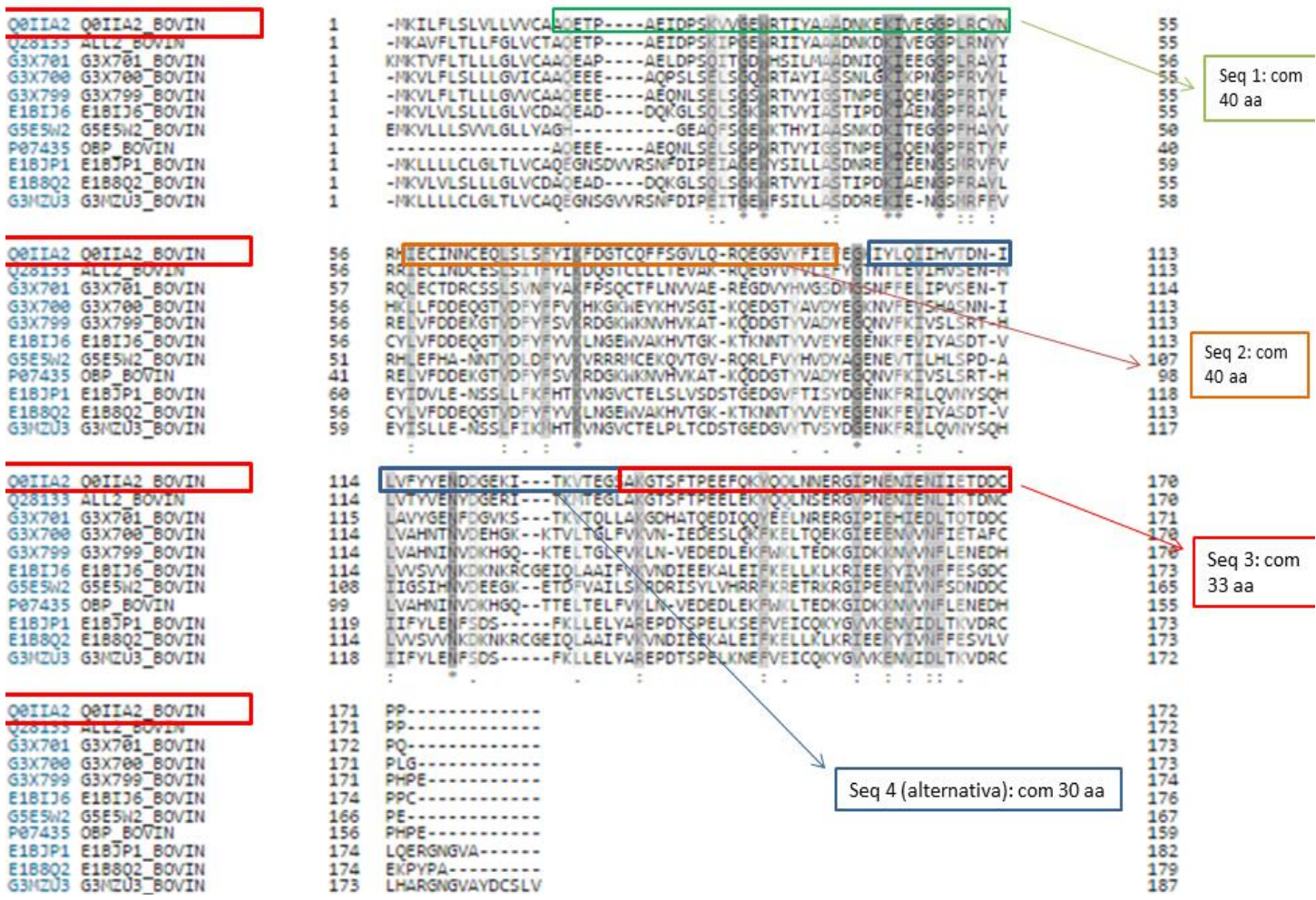

Tabela 02: Alinhamento de todas as sequências das lipocalinas presente em bovinos, deste alinhamento foi escolhido 3 sequências e destas 3 sequências escolhemos apenas a Seq 01, pois acreditamos que é a sequência que apresentava maior similaridade entre as proteínas e a que abrange a maior sequencia.

\subsubsection{Confirmação da produção do anticorpo e o reconhecimento do peptídeo} imunizado e o reconhecimento da lipocalina bovina em amostras coletadas.

A figura 29.A mostra que o SDS-Page apresentou bandas correspondentes ao peso molecular da cadeia leve (26 kDa) e pesada (69 kDa) da IgY, confirmando assim que o anticorpo foi produzido. Na figura 29.B quando avaliamos a atividade do anticorpo produzido (IgY anti- lipocalin) com o peptídeo imunizados podemos concluir que o anticorpo produzido esta reagindo com o peptídeo.

$\mathrm{Na}$ figura 29. C podemos confirmar que o anticorpo IgY realmente reconhece a bcOBP nas amostras coletadas de saliva e secreção nasal bem como a recombinante da lipocalina bovina (rbcOBP) . No mesmo western Blot foi utilizado duas canaletas com o 
anticorpo $\operatorname{IgM}$ anti- lipocalina bovina, para verificar se ao utilizar os dois anticorpos no ELISA poderia ocorrer uma interação entre eles, e como podemos concluir não ocorreu bandas positivas nas canaletas em que apresentavam o anticorpo IgM anti-lipocalina.

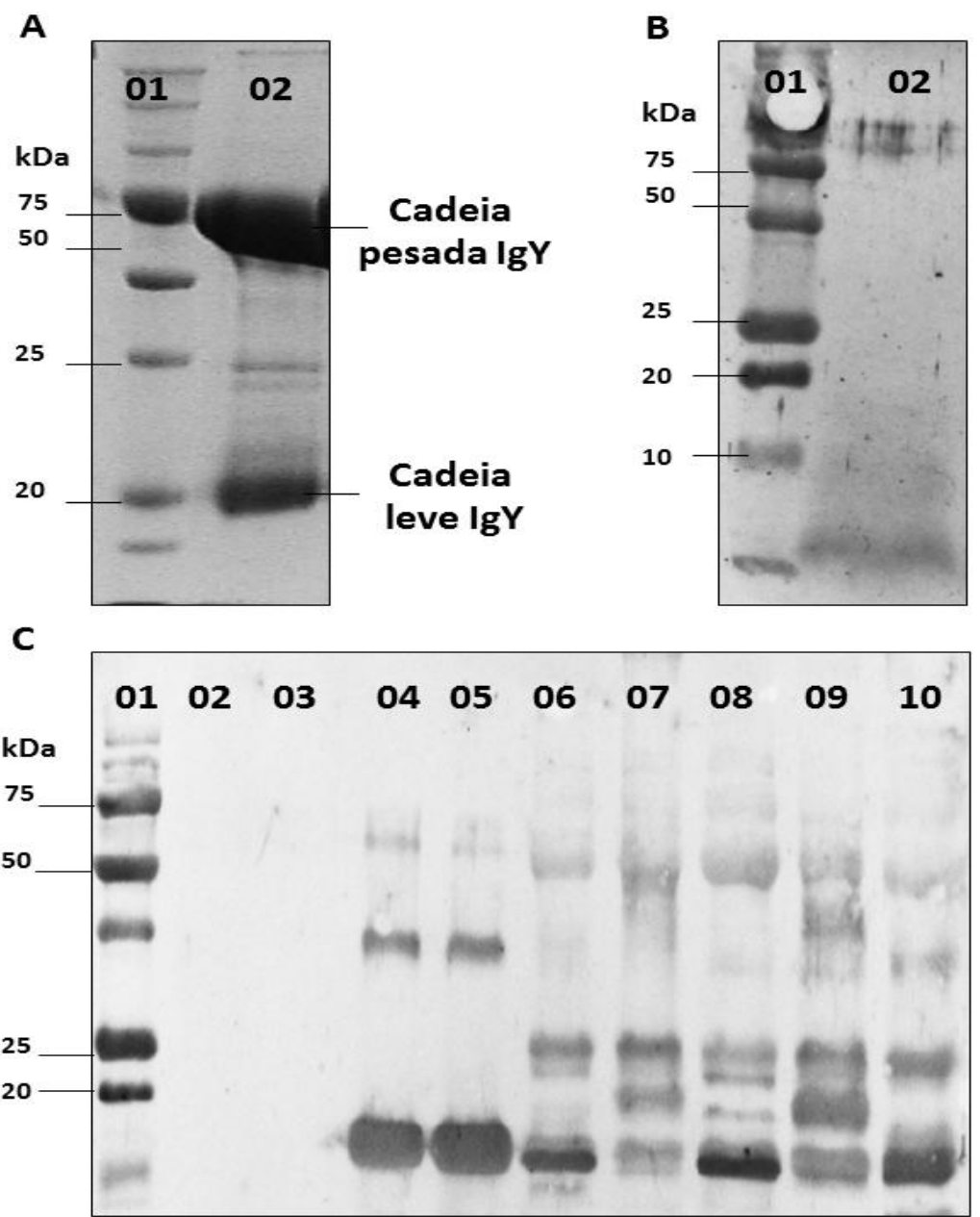

Figura 29: A) Confirmação da purificação do anticorpo IgY anti lipocalin (peptídeo). Gel SDS Page 12,5\%, canaleta 01: Peso molecular (6ul) e 02: Anticorpo IgY anti lipocalin (peptídeo, 5ul). Corado com coomassie. B) Confirmação do reconhecimento do peptídeo utilizado na imunização. Western Blot feito com o peptídeo, canaleta 01:peso molecular (10ul); 02: Peptideo usado para imunização da galinha (15ug). Revelado com ECL conforme instruções do fabricante. C) Confirmaçãa de que não ocorre interação entre os anticorpos IgM, reconhecimento da recombinante da lipocalina bovina (bcOBP) e amostras de secreção nasal e saliva. Canaleta 01: peso molecular; 02 e 03: IgM anti-lipocalin; 04 e 05: recombinante lipocalina bovina, 06: secreção nasal Holandês macho (30ug), 07: secreção nasal Holandês Fêmea (30ug), 08: saliva Holandês fêmea (30ug); 09: saliva Holandês Macho (30ug) e 10: saliva Nelore macho (30ug). 


\subsection{ELISA sandwich}

Foram utilizados dois designs para quantificar as amostras coletadas. No primeiro design foram adicionados o anticorpo de captura IgM anti-lipocalina, anticorpo de detecção IgY anti-lipocalin (peptídeo), e anti- IgY. No segundo design foram adicionados o anticorpo de captura IgY anti-lipocalina (peptídeo), anticorpo de detecção IgM anti lipocalin e anti- IgM.

Porém ao realizar os testes para padronização dos ELISAs com os dois designs verificamos que não foi possível fazer a quantificação das amostras por ELISA, pois foram feitas várias mudanças como: alterações na concentração do anticorpo de captura (por ex: 1:10;1:100; 1:500;1:1000; 1:2000), alterações nos bloqueios usando diferentes concentrações de albumina bovina $(2 \%, 5 \%$ e $10 \%)$, gelatina $(2 \%, 5 \%$ e $10 \%)$, bloqueio comercial $(2 \%, 5 \%$ e $10 \%)$, troca dos tampões de ligação carbonato pelo fosfato, troca das concentrações do anticorpo de detecção (por ex: 1:100; 1:1000; 1:2000; 1:4000).

Em todos os teste foi utilizado uma curva padrão com a proteína recombinante da lipocalina bovina. Entretanto, como os resultados podemos concluir que está ocorrendo alguma interação na reação que é revelada pelo branco. Além disso, verificamos que não há mudança na D.O (densidade ótica) que normalmente deveria cair pela metade do valor inicial, e que nem sempre ocorre um padrão entre as duplicatas. Tais resultados demonstram que não foi possível fazer a quantificação da lipocalina bovina (bcOBP), devido a alguma interação que está ocorrendo. 


\section{DISCUSSÃO}

A lipocalina bovina está dentro de uma classe de proteínas da família da Lipocalina chamada de Odorant Binding Protein (OBPs), que são responsáveis pela comunicação química entre os odorantes liberados no ambiente e os receptores de odorantes (Yu et al., 2009). Carrapatos conseguem localizar seus hospedeiros por diversos fatores, dentre estes fatores estão os compostos voláteis que são facilmente dispersados pelo vento por grandes distâncias, podendo então ficar por um bom tempo no ambiente, fornecendo assim uma informação segura da direção da fonte de liberação do composto volátil (Akerstrom et al., 2000; Flower et al., 2000; Guerin et al., 2000; Villela \& Dela Lúcia, 2001). Odores liberados por bovinos da raça Holandês (susceptíveis) e Nelore (resistentes) são distinguidos pelo carrapato R. microplus, e os carrapatos são mais atraídos por bovinos da raça Holandês (Borges et al., 2015).

Com base nos resultados de SDS-Page obtidos neste trabalho, possivelmente a bcOBP estaria presente nos fluidos coletadas como soro total (fig. 03), saliva (fig.04), suor (fig.05), secreção nasal (fig.06) e urina (fig.07) de touros e vacas em lactação da raca Nelore e HPB, pois ocorreu o aparecimento da banda de $20 \mathrm{kDa}$ em todos os fluidos. E conforme descrito as proteínas da família da lipocalina apresentam peso molecular de aproximadamente 20 kDa (Akerstrom et al., 2000; Flower et al., 2000).

Um grupo de pesquisadores desenvolveu um anticorpo monoclonal especifico para a bcOBP (IgM anti- lipocalina), este mesmo grupo demonstrou através de Western blot a presença da bcOBP nos seguintes fluidos: plasma sanguíneo, saliva, mucosa nasal, corrimento vaginal em vacas no período de lactação (Japaridze et al., 2012). E como é sabido existe diferença no grau de infestação por carrapatos entre as raças Nelore e HPB, e que também ocorre diferença na infestação por carrapatos de bovinos machos e fêmeas no período de lactação da mesma raça. Quando as fêmeas de bovinos estão no período de lactação são mais susceptíveis as infestações por carrapatos, possivelmente devido à interferência que hormônios sexuais estariam exercendo sobre o animal (Veríssimo, 1993).

Nossos resultados de Western blots de amostras de soro total (Figura 09.A, 10.A, 11.A e 12.A) nos permite concluir que touros e vacas em lactação de ambas as raças apresentam bcOBP no soro. E que existe uma diferença significativa de bcOBP para touros HPB quando comparados a touros Nelore (Figura 09.B), indicando que 
possivelmente a bcOBP pode auxiliar no carreamento de odorantes os quais tornam tais bovinos da raça HPB mais atrativos para o carrapato. $\mathrm{E}$ o mesmo ocorre quando avaliados touros e vacas da raça HPB (fig.10.B), uma possível justificativa para este dado é que as fêmeas estão no período de lactação, e conforme descrito por Japaridze e colaboradores, existe uma menor presença de bcOBP no plasma sanguíneo das vacas no período de lactação, pois acredita-se que a maior produção de bcOBP está presente no colostro. No entanto, não exclui a possibilidade de que a bcOBP é secretada no leite a partir do sangue, já que existem poucos trabalhos com bcOBP e ainda não é sabido seu local de origem e sua real função.

Os resultados de Western blot de saliva (Figura 13 e 14) de touros e vacas em lactação de ambas as raças, nos permite concluir que apenas touros e vacas da raça HPB apresentam bcOBP. Sugerindo que possivelmente a presença de bcOBP na saliva de HPB está auxiliando na liberação de odores que tornam essa raça mais susceptível ao carrapato, já que a raça Nelore não apresenta bcOBP na saliva. Nelores apresentam uma autolimpeza mais eficiente que HPB, porque sua língua contém papilas filiformes mais longas e um maior número de papilas por $\mathrm{cm}^{2}$ quando comparados ao HPB, tornando sua língua mais ásperas e mais eficaz na remoção de carrapatos durante a autolimpeza, conferindo assim uma maior resistência a Nelores (Veríssimo et al., 2015), então possivelmente a saliva que fica no couro dos bovinos HPB no processo de autolimpeza, esta auxiliando na liberando odores para o ambiente que tornam a raça HPB mais atrativa para o carrapato, conferindo assim uma maior susceptibilidade. Com os resultados na figura 15, podemos concluir que existe um aumento significativo de bcOBP na saliva de vacas em lactação quando comparados aos touros da raça HPB, este aumento pode auxiliar na atração de um maior número de carrapatos, tornando as vacas em lactação mais susceptíveis. Já que as vacas no período de lactação são mais susceptíveis a infestação por carrapatos devido à interferência de hormônios sexuais (Veríssimo, 1993).

Existe uma proteína da família da lipocalina conhecida por Bovine Odorant Binding protein (bOBP), que apresenta uma similaridade de $53 \%$ com a bcOBP, tal similaridade é considerada moderada (Fukuda et al. 2012). É produzida nas glândulas de suor e são transportadas para a pele (Rautiainen et al., 1998). Nas figuras 16, 17, 18 e 19 foi encontrada a presença de bcOBP no suor de touros e vacas em lactação da raça Nelore e HPB, porém não ocorreu diferença significativa entre os indivíduos analisados. 
Com estes resultados concluímos que a presença de bcOBP no suor possivelmente não está interferindo na resistência e susceptibilidade ao carrapato.

A proteína bOBP está descrita por ser abundante na mucosa nasal e por desempenhar um papel importante no transporte de odorante, como o 1-octen-3-ol que é uma substância volátil, encontrada de forma natural na respiração bovina. O composto 1-octen-3-ol é um potente atrativo para muitas espécies de insetos. Este composto pode auxiliar na atração de insetos, o que poderia ser um das funções da bOBP de auxiliar nas relações ecológicas entre as espécies bovina e de inseto (Ramoni et al., 2001).

Conforme descrito na literatura este mesmo composto (1-octen-3-ol) atua como atraente para carrapatos (McMahon et al., 2001). Os carrapatos reconhecem e diferenciam os odores liberados por seus hospedeiros, entre os semioquímicos descritos o odorante 1-octen-3-ol é característico de bovinos e provocou uma resposta significativa de atração do R. Micorplus. (Osterkamp et al., 1999).

Considerando que carrapato é um artrópode assim como os insetos, e que a proteína bOBP pertence a família da lipocalina apresentando uma similaridade moderada (53\%) com a bcOBP, e por ser encontrada em grande quantidade na mucosa nasal, quando avaliamos a presença de bcOBP na secreção nasal de touros e vacas em lactação das raças Nelore e HPB é possível sugerir com os resultados nas Figuras 20 e 21, que a bcOBP está auxiliando na liberação de um maior número de odorantes fazendo com que touros e vacas em lactação da raça HPB sejam mais atrativos para o carrapato que Nelores. Sabendo que bovinos da mesma raça apresentam diferenças no nível de susceptibilidade ao carrapato, e que as fêmeas quando estão no período de lactação são mais susceptíveis a infestações por carrapato que os machos, podemos então inferir que o aumento significativo de bcOBP (fig. 22) nas vacas em lactação da raça HPB quando comparados com os touros, também pode auxiliar na sua maior susceptibilidade a carrapatos.

Como é sabido na fase de busca pelo hospedeiro o carrapato pode perceber substâncias voláteis ou não voláteis liberadas pelo seu hospedeiro, ou também perceber subprodutos do desenvolvimento deste com as fezes e urina (Walladde, Rice, 1982 Caroll, 1998). Trabalhos demonstraram que existem proteínas na família da lipocalina que estão presente na urina de diversos mamíferos como, por exemplo, na urina de roedores (major urinary proteins -MUPs), o que inicialmente sugere um papel na comunicação química (Finlayson et al., 1965). Então, buscou-se avaliar a possível 
presença da bcOBP na urina de touros e vacas em lactação da raça Nelore e HPB (fig. 24), os resultados demonstraram que a bcOBP não está presente na urina dos animais estudados, o que nos permite concluir que a ausência da bcOBP na urina possivelmente não está influenciando na resistência e susceptibilidade ao carrapato.

Proteínas da família da lipocalina consideradas alérgenas, estão presentes na pele e glândulas sebáceas. Dentre elas estão as lipocalinas encontradas em felinos (Fel d1) (Charpin et al 1991), e Bos d 2 que são encontradas principalmente na camada baso lateral de biópsia de pele de bovino (MacKenzie and Casey, 1975). É sabido que bovinos zebuínos apresentam um maior número de glândulas sebáceas na pele, podendo então produzir odores os quais afastariam o carrapato (Gonzales, 1975). Com base nesses dados da literatura, e dados de nosso grupo de pesquisa ainda não publicados, existe uma maior expressão de gene odorant binding protein (pertencente a família da lipocalina) na pele de bovinos HPB em diferentes estágios das infestações (larva e ninfa) causado por $R$. microplus, o que possivelmente faz com que bovinos da raça HPB sejam mais atrativos para o carrapato. Com os dados de imuno-histoquímica na figura 25 e 26, é possível concluir que existe uma maior presença de bcOBP na pele de touros e vacas em lactação da raça HPB quando comparados a Nelore. Entretanto a maior presença da bcOBP na pele de bovinos da raça HPB pode auxiliar na liberação de odores mais atrativos ao carrapato, já que zebuínos liberam odores em sua pele que afastariam o carrapato e apresentam uma menor quantidade de bcOBP na pele e uma menor expressão do gene odorant binding protein. $\mathrm{O}$ mesmo trabalho não publicado do nosso grupo demonstra que em esfregaços de bovinos de ambas as raças as larvas e ninfas tiveram uma maior atração para bovinos da raça HPB. E entre bovinos das mesmas raças, porém de sexo diferentes os resultados demonstraram (fig. 27) que vacas em lactação da raça HPB apresentam mais bcOBP na pele quando comparados ao touros. Então, podemos sugerir que a bcOBP está tornando as fêmeas da raça Holandês mais susceptíveis a infestação por carrapato, devido a quantidade de odor liberado e por estarem no período de lactação.

Na Figura 29. A confirmou-se a purificação do anticorpo por sulfato de amônia através de gel SDS-Page, onde apresentou o peso molecular da cadeia pesada semelhante à maioria dos estudos descritos na literatura (Contreras et al., 2005, Garcia et al., 2005, Malekshahi et al., 2011, Mulvey et al., 2011, Ferella et al. Al., 2012 e Vega et al., 2012). Existem divergências na literatura quanto ao peso da cadeia leve. No 
entanto, nossos dados estão de acordo com os achados relatados por Garcia et al. (2005), Bernardo (2009), Mulvey et al. (2011), Cai et al. (2012), Ferella et al. (2012) e Vega et al. (2012). Na Figura 29.B-C confirmou-se o reconhecimento do anticorpo produzido para recombinante bcOBP em amostras de saliva e secreção nasal coletadas dos bovinos, e também foi confirmado que o anticorpo não está interagindo com a IgM utilizadas nos experimentos anteriores de Western blot que posteriormente foi usado no ELISA. Ao iniciar os testes de ELISA vimos que não foi possível fazer a quantificação das amostras por esta técnica, devido a problemas de interação na reação o qual não foi possível identificar.

Em síntese, podemos concluir que a bcOBP apresenta diferença significativa nos fluidos de saliva e secreção nasal de touros e vacas em lactação da raça HPB quando comparados com touros e vacas em lactação da raça Nelore. Em amostras de biópsia de pele também ocorreu uma maior marcação da bcOBP na raça susceptível (HPB), podendo então auxiliar na susceptibilidade destes bovinos ao carrapato, através do transporte de um maior número de odorantes que estariam atraindo um maior número de carrapatos. Ao analisar os fluidos entre bovinos da mesma raça, porém de sexo diferente, observou-se uma maior quantidade de bcOBP em vacas no período de lactação HPB nos fluidos de saliva e secreção nasal, visto que as vacas estão no período de lactação e são mais susceptíveis a infestações. Consequentemente, a bcOBP possivelmente está colaborando para a sua maior susceptibilidade quando comparadas com touros HPB, e o mesmo ocorreu para biopsia de pele. 


\section{CONCLUSÃO}

Os resultados obtidos neste trabalho permitem sugerir que a lipocalina bovina (bcOBP) presente em maior quantidade na saliva, secreção nasal, soro e biópsias de pele está auxiliando na susceptibilidade de touros e vacas em lactação da raça HPB quando comparados com touros e vacas em lactação da raça Nelore.

E mesmo nas análises entre bovinos da mesma raça, porém de sexo diferente, ocorreu uma diferença significativa para vacas em lactação HPB nos fluidos de saliva e secreção nasal, visto que as vacas estão no período de lactação e são mais susceptíveis a infestações. Portanto, a bcOBP pode colaborar para a sua maior susceptibilidade quando comparadas com touros HPB, e o mesmo ocorreu na biopsia de pele.

A bcOBP pode influenciar na atração de um maior número de carrapatos para bovinos da raça HPB, liberando odores para o ambiente que fariam com que bovinos da raça HPB sejam mais atrativos para o carrapato que os Nelore, visto que o carrapato consegue distinguir a diferença dos seus odores liberados no ambiente e ser mais atraído para bovinos da raça HPB. Então, a bcOBP estaria induzindo uma maior susceptibilidade desses bovinos Holandeses à infestação por R. microplus. 


\section{REFERÊNCIAS BIBLIOGRÁFICAS}

FRANZIN, A.M ., MARUYAMA, S.R., GARCIA, G. R., OLIVEIRA, R.P., RIBEIRO, J.M.C., BISHOP, R., MAIA, A. A. M., MORÉ, D.D., FERREIRA, B.R., SANTOS, I.K.F.M., Immune and biochemical responses in skin differ between bovine hosts genetically susceptible and resistant to the cattle tick, Rhipicephalus microplus. Parasites \& Vectors, No prelo.

ARTHUR, D.R. Ticks: A monograph of the Ixodoidea, On the genera Dermacentor Anocentor, Cosmiomma, Boophilus and Margaropus. London: Cambridge University Press, 374 p, 1960.

ANDREOTTI, R. Situação atual da resistência do carrapato-do-boi Rhipicephalus (Boophilus) microplus aos acaricidas no Brasil [online], 1. ed. Campo Grande: Embrapa Gado de Corte, 2010. Disponível em: http://www.cnpgc.embrapa.br/publicacoes/doc/DOC180.pdf. Acesso em: 04/10/2016

AKERTROM, B., FLOWER, D.R., and SALIER, J.P. Lipocalins: unity in diversity. Biochim. Biophys. Acta 1482, 1-8, 2000

BECHARA, G. H. Imunopatologia da interação carrapato-hospedeiro. In: BARROSBATTESTI, D. M.; ARZUA, M.; BECHARA, G. H. Carrapatos de importância médico veterinária da região neotropical: um guia ilustrado para identificação de espécies. 1. ed. São Paulo: Instituto Butantan,cap. 8, p.139-144, 2006.

BERNARDO, A.R. Tecnologia IgY: Produção de anticorpos aviários para Leishmania (Leishmania) amazonensis com o uso ético dos animais de experimentação Dissertação (Mestrado em Ciências) - Universidade Federal Rural do Rio de Janeiro, Seropédica, RJ, 60 pp, 2009.

BIGNETTI, E., CAVAGgiONI, A., PELOSI, P., PERSAUD, K.C., SORBI, R.T., and TIRINDELLI, R., Purification and characterisation of an odorant-binding protein from cow nasal tissue. European Journal of Biochemistry 149, 227-231, 1985. 
BORGES, L. M. F; DUARTE, S. C.; LOULY, C. C. B., Cattle tick differentiates between the odors of Holstein Friesian and Nelore cattle. Ciência Rural, v. 45, p. 2023 $2025,2015$.

CARROLl, J. F. Kairomonal activity of white-tailed deer metatarsal gland substances: a more sensitive behavioral bioassay using Ixodes scapularis (Acari: Ixodidae). Journal of Medical Entomology, v.35, n. 1, p. 90-93, 1998.

CARROLL, J. F. Responses of Three Species of Adult Ticks (Acari: Ixodidae) to Chemicals in the Coats of Principal and Minor Hosts. Journal of Medical Entomology, v. 36 (3), p. 238-242, 1999.

CARROOL, J. F. Responses of three species of adult ticks (Acari: Ixodidae) to chemicals in the coats of principal and minor hosts. Journal of Medical Entomology, v.36, n. 3, p. 238-242, 1999.

CARVAlHO, W. A., FRANZIN, A. M., ABATEPAUlO, A. R. R., OLIBEIRA, C. J. F., MORÉ, D. D.; SILVA, J. S., FERREIRA, B. R., DE MIRANDA SANTOS, I. K. F. M. Modulation of cutaneous inflammation induced by ticks in contrasting phenotypes of infestation in bovines. Veterinary Parasitology, Amsterdam, v. 167, p. 260-273, 2010.

CAI, Y.C. , GUO, J., CHEN, S.H., TIAN, L.G., STEINMANN, P., CHEN, M.X., LI, H., AI, L., CHEN, J.X. Chicken egg yolk antibodies (IgY) for detecting circulating antigens of Schistosoma japonicum Parasitol. Int., 61, pp. 385-390, 2012

CARVAlHO, W. A., MARUYANA, S. R., FRANZIN, A. M., ABATEPAUlO, A. R. R., ANDRERSON, J. M., FERREIRA, B. R., RIBEIRO, J. M. C., MORÉ, D. D., MAIA, A. A. M., VALENZUELA, J. G., GARCIA, G. R., DE MIRANDA SANTOS, I.K. F. Rhipicephalus (Boophilus) microplus: clotting time in tick-infested skin varies accordinf to local inflammation and gene expression patterns in tick salivary glands. Experimental Parasitology, Nova Iorque, p. 124, n. 428-435, 2010 b. 
CONTRERAS, V.T., LIMA, A.R., NAVARRO, A.C., ARTREAGA, R.Y., GRATEROL, D., CABELLO, L., FARIAS, M. Produción y purificación de anticuerpos (IgY) a partir de huevos de gallinas inmunizadas com epimastigotas de Trypanosoma cruzi Rev. FCS, 9, pp. 21-27, 2005.

CONSTATINOIU, C. C., JACKSON, L. A., JORGEGENSEN, W. K., LEWATABOR, A. E., PIPER, E. K., MAYER, D. G., VENUS, B., JONSSON, N. N. Local immune response against larvae of Rhipicephalus (Boophilus) microplus in Bos taurus indicus and Bos taurus taurus cattle. International Journal for Parasitology, Nova Iorque, v. 40, p. $865-875,2010$.

CHARPIN, C., MATA, P., CHARPIN, D., LAVAUT, M. N., AllaSia, C., VERVLOET, D, Fel d I allergen distribution in cat fur and skin. J Allergy Clin Immunol, 88:77-82, 1991.

DA ROCHA, C.M.B.M. Aspectos relevantes da biologia do Boophilus microplus (Cannestrini, 1887). Boletim da Universidade Federal de Lavras (on-line). http://www.editora.ufla.br/Boletim/pdf/bol_32.pdf

DE LA FUENTE, J., RODRIGUEZ, M., MONTEIRO, C., REDONDO, M., GARCIAGARCIA, J. C, et al. Vaccination against ticks (Boophilus spp.): the experience with the Bm86-based vaccine Gavac. Genet Anal, vol. 15, p.143-148, 1999. Disponível em: < http://www.ncbi.nlm.nih.gov/pubmed/10596754>.

FABBRO, S.; NAZZI, F. From Chemistry to Behavior. Molecular Structure and Bioactivity of Repellents against Ixodes ricinus Ticks. Plos One, v. 8, n. 6, p. 1-9, 2013.

FERELlA, A., BELliDO, D., CHACANA, P., WIGDOROVITZ, A., DUS SANTOS, M.J., MOZGOVOJ, M.V. Chicken egg yolk antibodies against bovine respiratory syncytial virus neutralize the virus in vitro Proc. Vaccinol., 6 (2012), pp. 33-38 
FERREIRA, J. T. B. Produtos naturais no controle de insetos. 1. ed. São Carlos, UFSCar, 175p., 2001.

FERREIRA, L. L. Respostas eletrofisiologicas das porosensilas da queliceras deE Ripicephalus microplus Frente a fogoestilumante e soros de bovinos. Dissertação (Mestrado em Ciência Animal) Escola de Veterinária e Zootecnia, Universidade Federal de Goias, Goiânia, 48 f, 2013.

FRANCISCHETTI, I.M.B., SÁ-NUNES, A., MANS, B.J., SANTOS, I.M., RIBEIRO, J.M.C., The role of saliva in tick feeding. Front Biosci. vol. 14, p.2051-2088, 2010. Disponível em: < http://www.ncbi.nlm.nih.gov/pubmed/19273185>.

FLECHTMANN, C. H. W. Ácaros de importância médico veterinária. 3. ed. São Paulo: Nobel, 192 p., 1990.

FLOWER, D.R., NORTH, A.C.T., and ATTWOOD, T.K. Structure and sequence relationships in the lipocalins and related proteins. Protein Science 2, 753-761, 1993.

FLOWER, D.R. The lipocalin protein family: structure and function. Biochem. J. 318 ( Pt 1), 1-14. 1996.

FLOWER, D.R., NORTH, A.C., and SANSOM, C.E. The lipocalin protein family: structural and sequence overview. Biochim. Biophys. Acta 1482, 9-24, 2000.

GARCIA, D.A., NICHOLlS, R.S., ARÉVAlO, A., TORRES, O., DUQUE, S. Obtención, purificación y caracterización de anticuerpos policlonales IgY desarrolados em gallina, dirigidos contra aislamientos colombianos de Giardia duodenalis. Biomédica, 25, pp. 451-463, 2005.

GONZALES, J.C. O carrapato do boi: vida, resistência e controle. São Paulo: Mestre Journal, 101p., 1974. 
GONZALES, J.C. O controle dos carrapatos dos bovinos. Porto Alegre: Sulina,104p., 1975.

GONZALES, J. C. O controle dos carrapatos do boi. 2. ed. Porto Alegre: Edição do Autor, 1995.

GUERIN, P. M., KRÖBER, T., McMAHON, C., GUERENSTEIN, C., GRENACHER, S.; VLIMANT, M., DIEHL, P. A., STEUllET, P., SEYD, Z., 46 Chemosensory and behavioural adaptations of ectoparasitic arthropods. Nova Acta Leopoldina, Halle, v. 83, p. 197-213, 2000.

GRZYB, J., LATOWSKI, D., and STRZALKA, K. Lipocalins - a family portrait. J. Plant Physiol. 163, 895-915, 2006.

GUIRAUDIE-CAPRAZ, G., SLOMIANNY, M.-C., PAGEAT, P., MALOSSE, C., CAIN, A.-H., ORGEUR, P., E NAGNAN-LE MEILLOUR, P. Biochemical and Chemical Supports for a Transnatal Olfactory Continuity through Sow Maternal Fluids. Chemical Senses 30, 241-251, 2005.

JAPARIDZE, T., SENDA, A., NOZAKI, H., YANAGIDA, M., SUZUKI, T., GANZORIG, K., KUSHI, Y., KIDA, K., URASHIMA, T., BRUCKMAIER, R.M., et al. Cloning, monoclonal antibody production, and bodily distribution pattern of a bovine lipocalin. Biosci. Biotechnol. Biochem. 76, 712-720, 2012.

KONGSUWAN, K., JOSH, P., COLGRAVE, M. L., BAGNALL, N. H., GOUGH, J., BURNS, B., PEARSON, R. Activation of several key components of the epidermal differentiation pathway in cattle following infestation with the cattle tick, Rhipicephalus (Boophilus) microplus. International Journal for Parasitology, cidade, n. 40, p. 499$507,2010$. 
LABRUNA, M. B., PEREIRA. M. C. Carrapatos em cães no Brasil. Clínica Veterinária, v. 6, n. 30, p. 24-32, 2001.

LOGAN, J. G., BIRKETT, M. A. Review semiochemicals for biting fly control: their indetification and explotation. Pest Management Science, Sussex, v. 63, p. 647-657, 2007.

MADALENA, F.E., TEODORO, R.H., LEMOS, A.M., OLIVEIRA, G.P. Causes of variation of field burdens of cattle ticks (B. microplus). Revista Brasileira de Genética, Ribeirão Preto, v.VIII, n.2, p.361-75.1985.

MALEKSHAHI, Z.V., GARGARI, S.L.M., RASOOLI, I., EBRAHIMIZADEH, W. Treatment of Helicobacter pylori infection in mice with oral administration of egg yolkdriven anti-UreC immunoglobulin Microb. Pathog., 51, pp. 66-372, 2011.

MCMAHON, C., GUERIN, P.M., e SYED, Z. 1-octen-3-ol isolated from bont ticks attracts Amblyomma variegatum. J. Chem. Ecol. 27, 471-486, 2001.

MCMAHOM, C., GUERIN, P. M. Attraction of the tropical bont tick, Amblyomma variegatum, to human breath and to the breath components acetone, NO and $\mathrm{CO} 2$. Naturwissenschaften, v. 89, p 311-31, 2002.

MUlVEY, G.L., DINGLE, T.C., FANG, L., STRECKER, J., ARMSTRONG, G.D. Therapeutic potential of egg yolk antibodies for treating Clostridium difficile infection J. Med. Microbiol., 60, pp. 1181-1187, 2011.

MURRELL, A., e BARKER, S.C. Synonymy of Boophilus Curtice, 1891 com Rhipicephalus Koch, 1844 (Acari: Ixodidae). Syst. Parasitol. 56, 169-172, 2003.

MATTIOLI, R. C., CASSMA, M. Comparison of characteristics of life cycle in female ticks collected on N'Dama and Zebu cattle. Trop An Health Prod. 27:150-4. 1995. 
MATTIOLI, R. C., PANDEY, V. S., MURRAY, M., FITZPATRICK, J.L. Immunogenetic in Xuences on tick resistance in African cattle with particular reference to trypanotolerant N'Dama (Bos taurus) and trypanosusceptible Gobra zebu (Bos indicus) cattle. Acta Trop., 75:263-77, 2000.

OLIVEIRA, G.P., ALENCAR, M.M., FREITAS, A.R. Resistência de bovinos ao carrapato B. microplus II. Infestação natural. Pesquisa Agropecuária Brasileira, Brasília, v.24, n.10, p.1267-1271.1989.

OLIVEIRA, G.P.; ALENCAR, M.M. Resistência de bovinos de seis graus de sangue Holandês-Guzerá ao carrapato (Boophilus microplus) e ao berne (D. hominis). Arquivo Brasileiro Medicina Veterinária Zootecnia, Belo Horizonte, v.42, n.2, p.127-35. 1990.

OSTERKAMP, J., WAHL, U., SCHMALFUSS, G., HAAS, W. Host-odour recognition in two tick species is coded in a blend of vertebrate volatiles. Journal of Comparative Physiology A: Neuroethology, Sensory, Neural, and Behavioral Physiology, v.185, n. 1, p. 59-67, 1999.

PELOSI, P. The role of perireceptor events in vertebrate olfaction. Cell. Mol. Life Sci. $58,503-509.2001$.

PERVAIZ, S., e BREW, K. Homology of beta-lactoglobulin, serum retinol-binding protein, and protein HC. Science 228, 335-337, 1985.

PEVSNER, J., TRIFILETTI, R.R., STRITTMATTER, S.M., e SNYDER, S.H. Isolation and characterization of an olfactory receptor protein for odorant pyrazines. Proc. Natl. Acad. Sci. U.S.A. 82, 3050-3054, 1985. 
PICKETT, J. A.; BIRKETT, M. A.; DEWHIRST, S. Y.; LOGAN, J. G.; OMOLO, M. O.; TORTO, B.; PELLETIER, J.; SYED, Z.; LEAL, W. S. Chemical ecology of animal and human pathogen vectors in a changing global climate. Journal Chemical Ecology, New York, v. 36, p. 113-121, 2010.

PIPER E.K, JONSSON N.N, GONDRO C, LEW-TABOR A.E, MOOLHUIJZEN P, VANCE M.E, JACKSON L.A. Immunological Profiles of Bos taurus and Bos indicus Cattle Infested with the Cattle Tick, Rhipicephalus (Boophilus) microplus. Clinical and Vaccine Immunology, vol.16, p.1074-1086, 2009. Disponível em: < http://www.ncbi.nlm.nih.gov/pubmed/19474263>.

POWEEL R; REID T. Project tick control. 6, vol.108, n.6, p.279-300, 1982.

RAMONI, R., VINCENT, F., GROLLI, S., CONTI, V., MALOSSE, C., BOYER, F.D., Nagnan-Le Meillour, P., Spinelli, S., Cambillau, C., and Tegoni, M. The insect attractant 1-octen-3-ol is the natural ligand of bovine odorant-binding protein. J. Biol. Chem. 276, 7150-7155, 2001.

RODRIGUEZ M, PENICHET ML, MOURIS AE, LABARTA V, LUACES LL, ET AL. Control of Boophilus microplus populations in grazing cattle vaccinated with a recombinant Bm86 antigen preparation. Vet Parasitol., vol. 57, p.339-349, 1995. Disponível em: < http://www.ncbi.nlm.nih.gov/pubmed/7660571>.

SEIFERT, G. W. Variations between and within breeds of cattle in resistance to field infestations of the cattle tick. Australian Journal of Agricultural Research, Collingwood, v. 22, p. 159-168, 1970.

SOARES, S. F.; LOULY, C. C. B.; MARION-POLL, F.; RIBEIRO, M. F. B.; BORGES, L. M. F.; Study on cheliceral sensilla of the brown tick Ripicephalus sanguineus (Latreille, 1806) (Acari:Ixodidae) involved in taste perception of phagostimulants. Acta Tropica, n. 126, p. 75-83, 2013. 
SONENSHINE, D. E. Biology of ticks. vol. 1. New York: Oxford University Press, 1991. $447 \mathrm{p}$.

SONENSHINE, D. E. Biology of ticks. vol. 2. New York: Oxford University Press, 1993. $465 \mathrm{p}$.

SONENSHINE, D. E. Pheromones and other semiochemicals of ticks and their use in tick control. Parasitology, Cambridge, v. 129, p. 405-425, 2004.

SUTHERST, R.W., KERR, J.D., MAYWALD, G.F., STEGEMAN, D.A. The effect of season and nutrition on the resistance of cattle to the tick Boophilus microplus. Aust. J. Agric. Res. V.34, n.3, p.329-339, 1983.

STEULLET, P., GUERIN, P. M. Identification of vertebrate volatiles stimulating olfactory receptors on tarsus I of the tick Amblyomma variegatum Fabricius (Ixodidae). Journal of Comparative Physiology A: Neuroethology, Sensory, Neural, and Behavioral Physiology, v.174, n. 1, p. 27-38, 1994.

SZABÓ, M. P. J., ROSSI, G. F., CABRAL, D. D., MARTINS, M. M., AMORIM, G. M. P., TSURUTA, S. A. Experimental evaluation of birds as disseminators of the cosmopolitan tick Rhipicephalus sanguineus (Acari: Ixodidae). Experimental Parasitology, v. 132, p. 389-393, 2012.

TIZARD, I. R. Imunologia veterinária: uma introdução. 6. ed. São Paulo: Roca, 2002.

UTECH, K.B.W., WHARTON, R..H., KERR, D.J. Resistance to B. microplus (Canestrini) in different breeds of cattle. Australian Journal Agricultural Research., East Melbourne, v.29, n.4, p.885-95. 1978.

VEGA, C.G., BOK, M., VLASOVA, A.N., CHATTA, K.S., FERNÁNDEZ, F.M., WIGDOROVITZ, A., PARRENÕ, V.G., SAIF, L.J. IgY antibodies protects against human rotavirus induced diarrhea in the neonatal gnotobiotic piglet disease model, PLoS ONE, 7, 2012 
VERÍSSIMO, C.J. Resistência e suscetibilidade de bovinos leiteiros mestiços ao carrapato Boophilus microplus. Jaboticabal: Faculdade de Ciências Agrárias e Veterinárias - UEP, 170p. (Dissertação-Mestrado em Produção Animal). 1991.

VERÍSSIMO, C.J. Controle do carrapato dos bovinos. Jaboticabal, FUNEP, 26p, 1993.

VERÍSSIMO, C.J., MACHADO, S.G. Fase de vida livre do ciclo evolutivo do carrapato Boophilus microplus. Zootecnia, Nova Odessa, v.33, n.2, p.41-53, 1995.

VERÍSSIMO, C.J., D’AGOSTINO, S.M., PESSOA, F.F., DE TOLEDO, L.M., e DE MIRANDA SANTOS, I.K.F. Length and density of filiform tongue papillae: differences between tick-susceptible and resistant cattle may affect tick loads. Parasites \& Vectors 8., 2015.

VILELA, E. F., LUCIA, T. M. C. Feromônios de insetos: biologia, química e emprego no manejo de pragas. 2. ed. São Paulo: Holos, 206 p, 2001.

VILLARES, J.B. Climatologia Zootécnica. III. Contribuição ao estudo da resistência e susceptibilade genética dos bovinos ao B. microplus. Boletim de Indústria Animal, São Paulo,v.4, n.1, p.60-79, jan/jun.1941.

YU, F., ZHANG, S., ZHANG, L., e PELOSI, P. Intriguing similarities between two novel odorant-binding proteins of locusts. Biochem. Biophys. Res. Commun. 385, 369$374,2009$.

WAGLAND B.M, Host resistance to cattle tick (Boophilus microplus) in Brahman (Bos indicus) cattle. II. The dynamic of resistance in previously unexposed and exposed cattle. Australian Journal of Agricultural Research, 29 (2), 395-400,1978. 
WALADDE, S. M.; RICE, M. J. The sensory nervous system of the adult cattle tick Boophilus microplus (Canestrini) Ixodidae. Part III. Ultra-structure and electrophysiology of the cheliceral receptors. Australian Journal of Entomology, Camberra, v. 16, n. 4, p. 441-453, 1977.

WALADDE, S. M. Tip-recording from ixodid tick olfactory sensilla: Responses to tick related odours. Journal of Comparative Physiology A: Neuroethology, Sensory, Neural, and Behavioral Physiology, v.148, n. 4, p. 411-418, 1982.

WALADDE, S. M.; RICE, M. J. The sensory basis of tick feeding behaviour. . In: OBEnCHAin, F. D.; GALUN, R. Physiology of ticks. 1. ed. Oxford: Pergamon, cap. 3, p. 71-118, 1982.

WAMBURA, P. N.; GWAKISA, P.S.; SILAYO, R. S.; RUGAIMUKAMU, E. A. Breed-associated resistance to tick infestation in Bos indicus and their crosses with Bos taurus. Veterinary Parasitology, Amsterdam, v. 77, p. 63-70, 1998.

WIKEL, S. K. Host immunity to ticks. Annual Review of Entomology, Palo Alto, v. 41, p. 1-22, 1996.

WIKEL, S. K.; BERGMAN, D. Tick host immunology: significance advances and challenging opportunities. Parasitology today, Oxford, v. 13, p. 383-389, 1997. 